\author{
UNIVERSIDADE DE SÃO PAULO \\ ESCOLA DE COMUNICAÇÕES E ARTES \\ DEPARTAMENTO DE MÚSICA
}

DANIEL APARECIDO DE OLIVEIRA

A colaboração entre compositor e intérprete - Concerto para clarineta e orquestra de Magnus Lindberg: abordagens interpretativas

São Paulo

2020 
DANIEL APARECIDO DE OLIVEIRA

\section{A colaboração entre compositor e intérprete - Concerto para clarineta e orquestra de} Magnus Lindberg: abordagens interpretativas ${ }^{1}$

Dissertação apresentada ao Programa de PósGraduação em Música da Escola de Comunicação e Artes da Universidade de São Paulo para obtenção do título de Mestre em Música.

Área de concentração: Processos de criação musical Performance.

Orientador: Prof. Dr. Luís Antonio Eugenio Afonso

São Paulo

2020

${ }^{1}$ Versão Corrigida (versão original disponível na Biblioteca da ECA/USP 
Dados Internacionais de Catalogação na Publicação (CIP)

O49c Oliveira, Daniel Aparecido de

A colaboração entre o compositor e intérprete - Concerto para clarineta e orquestra de Magnus Lindberg: abordagens interpretativas. / Daniel Aparecido de Oliveira; orientador, Luis Antonio Eugenio Afonso. - São Paulo, 2020.

102 f.: il.

Bibliografia

Versão corrigida

Dissertação (Mestrado) - Programa de Pós-Graduação em Música - Escola de Comunicações e Artes / Universidade de São Paulo.

1. Performance musical. 2. Clarineta. 3. Colaboração entre compositores e intérpretes. I. Afonso, Luis Antonio Eugenio. II Título.

CDD 21 ed. - 780

Bibliotecária Responsável: Márcia Silva Augusto, CRB8-10322 


\section{AGRADECIMENTOS}

À minha família, sobretudo meus pais, Jonas Oliveira e Sueli de Fátima Paula, pelo amor incondicional e incentivo nos estudos.

À minha companheira, Rafaela Lopes, pelo amor, paciência, compreensão e colaboração, tanto nas audições do concerto como na leitura deste trabalho. Sempre me apoiando e me motivando nos projetos impossíveis.

Ao meu orientador, Luis Afonso (Montanha), pela amizade, incentivo e confiança, sempre generoso no compartilhamento de suas experiências e conhecimentos.

A todos os professores que me acompanharam em minha trajetória, em especial ao Mestre Sérgio Burgani por ter me ensinado não só a tocar clarineta mas a amar incondicionalmente a nossa arte.

Ao amigo irmão Diogo Maia, pelas intermináveis conversas e reflexões, pela generosa revisão deste trabalho e por sempre embarcar nas minhas aventuras clarinetísticas.

Ao clarinetista Kari Kriikku, pela atenção e pronta elucidação das dúvidas.

Aos mestres que nos ensinam todos os dias Joel Barbosa, Mauricio Loureiro, Luca Raele e Edmilson Nery.

Aos maestros e amigos, Luis Fernando Malheiro, Otávio Simões e Marcelo de Jesus pela coragem e generosidade em programar uma obra contemporâneo e ao maestro Guilherme Mannis, pela competente condução do Concerto para Clarineta, interpretado brilhantemente pelos colegas da Amazonas Filarmônica - AM

Aos docentes do Programa de Pós-Graduação em Música da Universidade de São Paulo, em especial aos professores Ricardo Bologna, Eliane Tokeshi, Susana Cecilia Igayara de Souza, Roberto Suetholz, Silvio Ferraz, Ricardo Ballestero e Gil Jardim, pelas discussões e pelos conhecimentos adquiridos nesta caminhada. 
OLIVEIRA, Daniel Aparecido de. A colaboração entre compositor e intérprete - Concerto para clarineta e orquestra de Magnus Lindberg: abordagens interpretativas. Orientador: Luís Antonio Eugenio Afonso, 2020. 102 f. Dissertação (Mestrado em Música) - Escola de Comunicação e Artes, Universidade de São Paulo, 2020.

Aprovado em: 09/10/2020

Banca Examinadora

Prof. Dr.:

Instituição:

Julgamento:

Prof. Dr.:

Instituição:

Julgamento:

Prof. Dr.:

Instituição:

Julgamento: 


\section{DEDICATÓRIA}

Ao meu amor, Rafaela Lopes, pela caminhada juntos. 


\section{O MANIFESTO DOS AULOS}

Somos descendentes da tribo dos sopradores de aulos. A magia dos Aulos está na sua total liberdade de expressão. Nada nos inibe: deuses, sexo, animais (racionais ou não), raças, ideologias... Misturamos o velho e o novo. Tudo cabe na Panacéia Aulólica. Só não suportamos o mau caratismo: um ser dito racional prejudicar um semelhante; prejudicar um ser dito irracional; a natureza; a vida. Não acreditamos em deuses nem em mitos. Fora com os gogós. Todo ser, humano ou não, é igual na sua formosura. Nossas aulodias tem compromisso férreo com o amor e o tesão que são o motor da vida.

Naurício G. Raimondo 
OLIVEIRA, Daniel Aparecido de. A colaboração entre compositor e intérprete - Concerto para clarineta e orquestra de Magnus Lindberg: abordagens interpretativas. Orientador: Luís Antonio Eugenio Afonso, 2020. 102 f. Dissertação (Mestrado em Música) - Escola de Comunicação e Artes, Universidade de São Paulo, 2020.

\section{RESUMO}

O presente trabalho procura relatar a importância das colaborações entre compositores e intérpretes na história da clarineta e utiliza como referência a colaboração entre o compositor Magnus Lindberg e o clarinetista Kari Kriikku na compreensão e classificação deste processo nos dias atuais. Sendo o Concerto para Clarineta (2002), a obra mais significativa desta colaboração, relatamos neste trabalho como as habilidades inerentes ao intérprete colaborador, podem auxiliar e transformar a elaboração de novas abordagens técnico interpretativas. Como resultado dessas decisões adotadas, anexamos um registro em formato audiovisual da performance do concerto por este pesquisador.

Palavras-chave: Colaboração compositor-intérprete. Performance musical. Clarineta. 


\begin{abstract}
The present work seeks to report the importance of collaborations between composers and interpreters in the history of the clarinet and uses as a reference the collaboration between the composer Magnus Lindberg and the clarinetist Kari Kriikku in the understanding and classification of this process today. As the Clarinet Concerto (2002), the most significant work of this collaboration, we report in this work how the abilities inherent to the collaborating interpreter, can help and transform the elaboration of new technical interpretive approaches. As a result of these decisions, we attached a video record of the performance of the Concert by this researcher.
\end{abstract}

Keywords: Composer-interpreter collaboration. Performance musical. Clarinet. 


\section{LISTA DE FIGURAS}

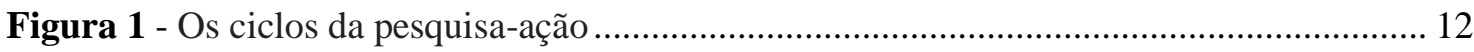

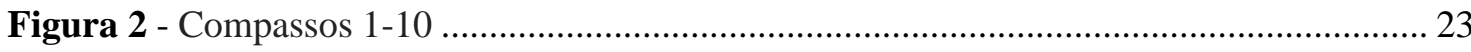

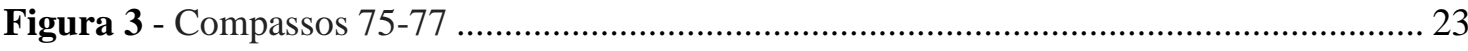

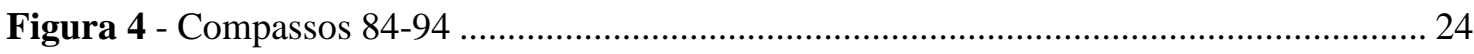

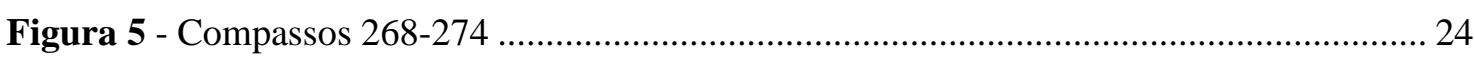

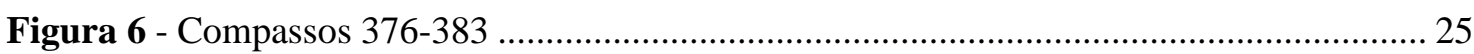

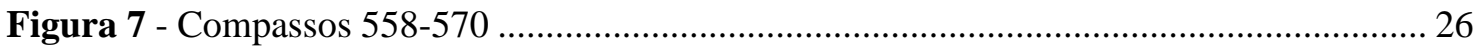

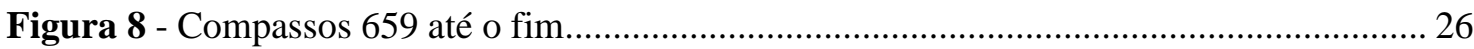

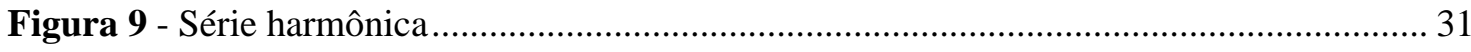

Figura 10 - Notas destacadas da série harmônica .................................................................... 31

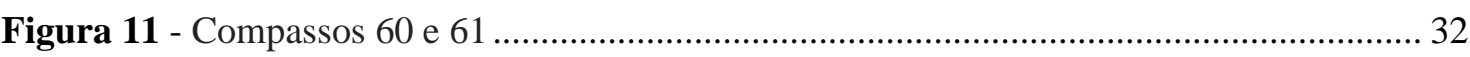

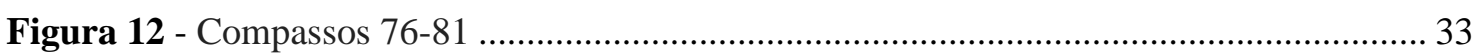

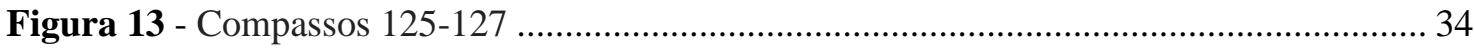

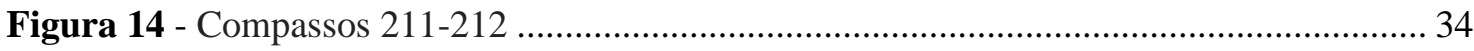

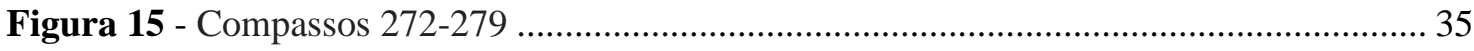

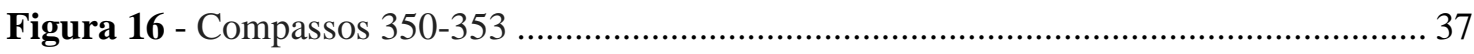

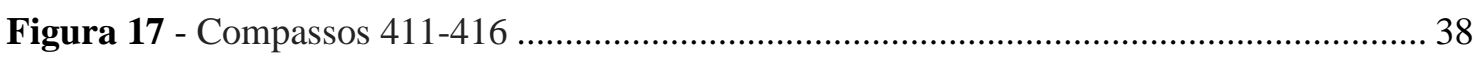

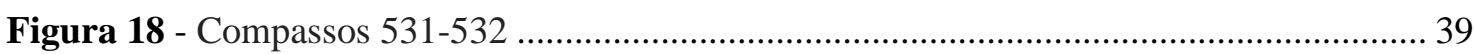

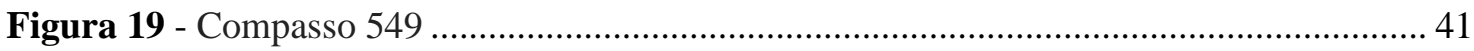

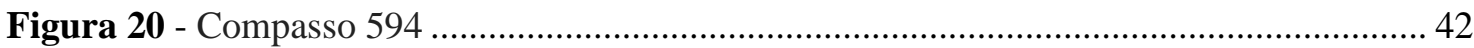

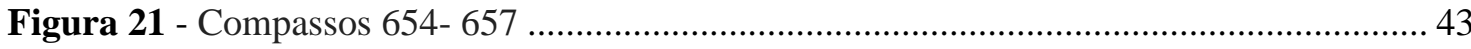

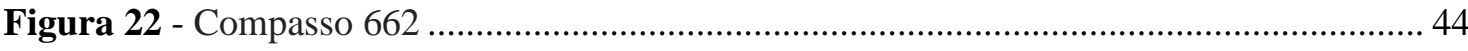

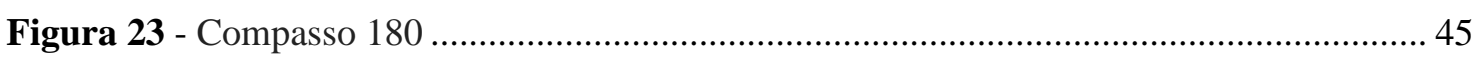

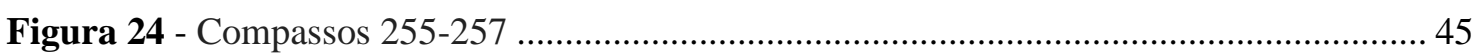

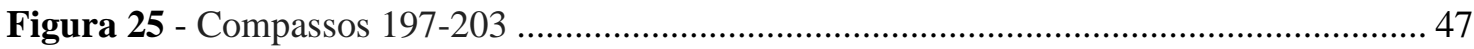

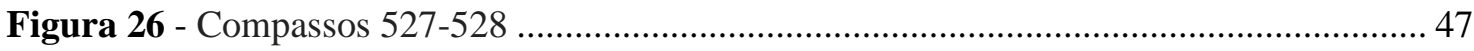

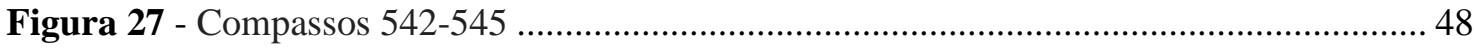

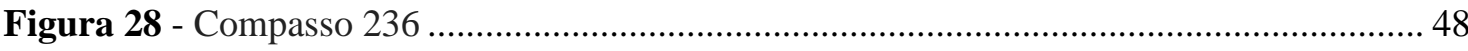

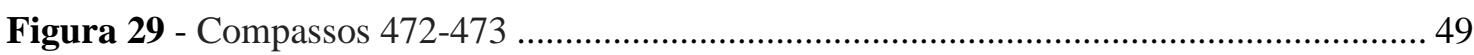

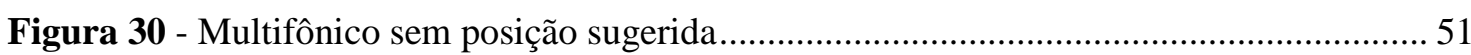

Figura 31 - Multifônico com posição sugerida .................................................................. 51

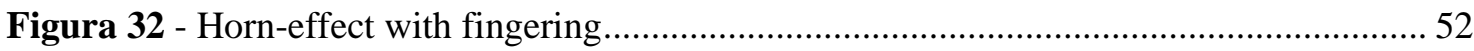

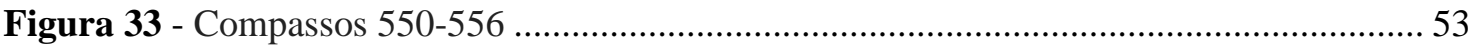

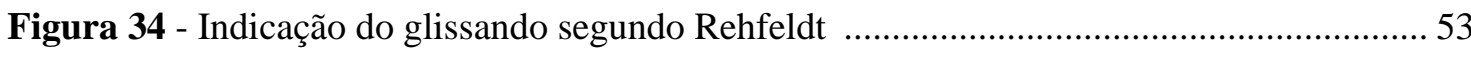

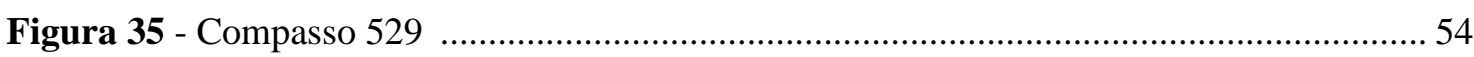

Figura 36 - Flyer de divulgação do concerto ……………..................................................... 59 


\section{SUMÁRIO}

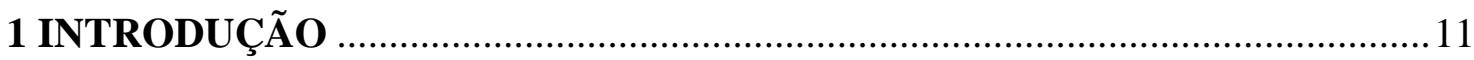

1.1 DESENVOLVIMENTO IDIOMÁTICO NA CLARINETA …................................. 13

1.2 A COLABORAÇÃO ENTRE COMPOSITORES E INTÉRPRETES NA HISTÓRIA

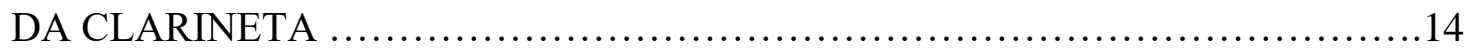

1.3 REFERÊNCIAS NO ESTUDO DA COLABORAÇÃO ....................................... 16

2 CONCERTO PARA CLARINETA E ORQUESTRA DE MAGNUS LINDBERG

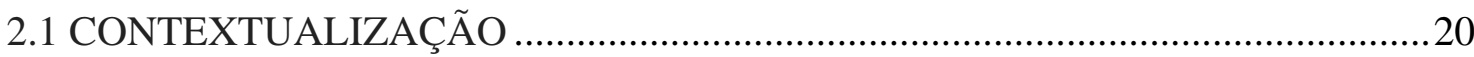

2.2 ABORDAGEM TÉCNICO-INTERPRETATIVA................................................ 27

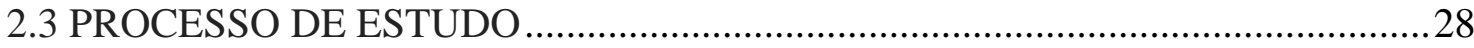

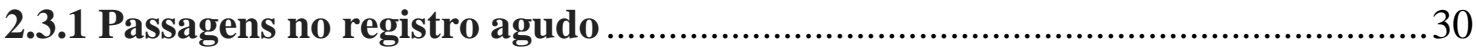

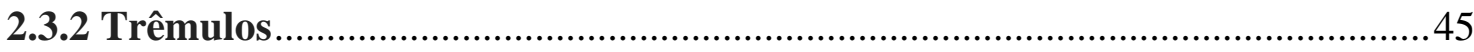

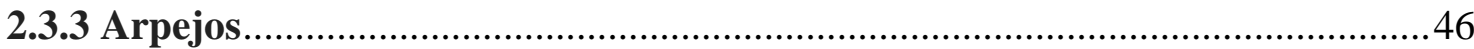

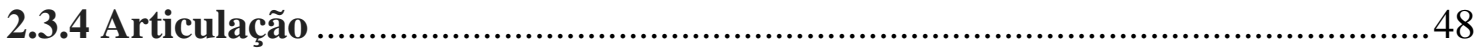

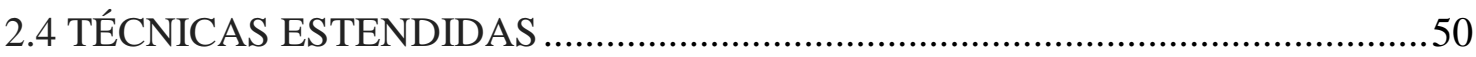

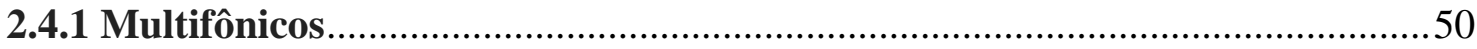

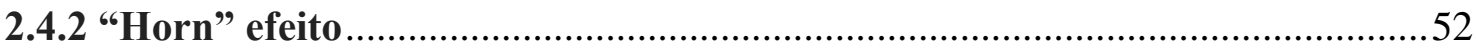

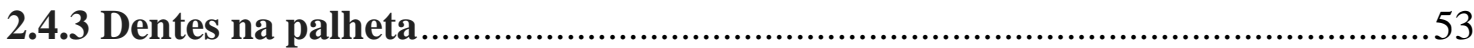

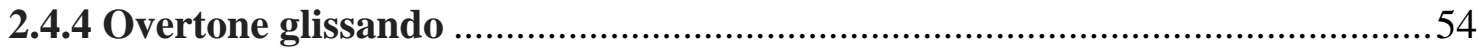

2.5 INTERFERÊNCIAS NO CONTEXTO DE TRABALHO ......................................55

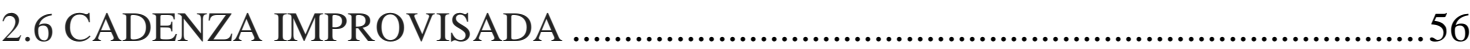

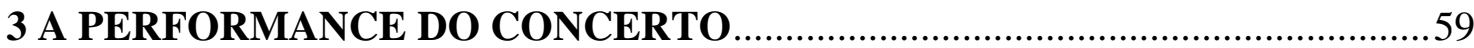

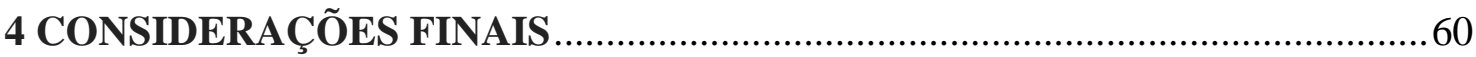

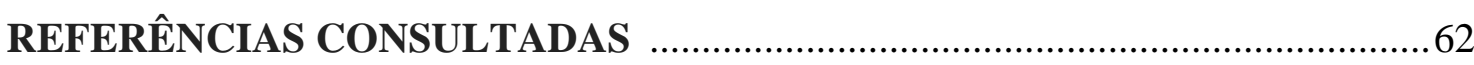

APÊNDICE A - TABELA DE COLABORAÇÃO COMPOSITOR / INTÉRPRETE /

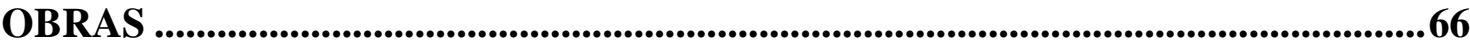

APÊNDICE B - PLANO DE TRABALHO ....................................................................69

ANEXOS - PARTITURA DO CONCERTO PARA CLARINETE DE MAGNUS

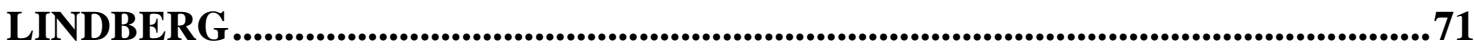




\section{INTRODUÇÃO}

O presente trabalho teve início após a apresentação por este pesquisador da peça $A B L A U F$ de Magnus Lindberg. Esta peça gerou um interesse em conhecer outras obras do compositor, em especial as obras dedicadas à clarineta. Durante este processo encontramos em todas as peças para clarineta e em suas respectivas gravações, menções ou dedicatórias ao clarinetista Kari Kriikku, o que levantou uma questão: qual seria o papel deste intérprete no processo de composição de Lindberg? Com o intuito de realizar uma pesquisa sistematizada, apresentei um projeto de pesquisa ao Programa de Pós-Graduação em Música da Universidade de São Paulo - USP, com o objetivo de responder outras questões além dessa, como: desde quando a colaboração entre compositor e intérprete está presente na história da clarineta? Como se desenvolve o processo de colaboração e como são classificados. Como o intérprete colaborador influência idiomaticamente o compositor na elaboração de sua obra? Como outros intérpretes podem executar este repertório? Como utilizar o conhecimento das habilidades intrínsecas do intérprete colaborador empregadas nas obras?

Adotamos como objeto teórico a colaboração entre o compositor Magnus Lindberg e o clarinetista Kari Kriikku, e como objeto prático o Concerto para Clarineta e Orquestra, peça segundo o compositor de maior relevância dedicada ao instrumento e onde desenvolveu-se uma efetiva colaboração.

A primeira parte da dissertação é direcionada para as referências de colaborações na história do instrumento e com o auxílio da bibliografia consultada, elaboramos uma tabela onde é descrito relevantes cooperações e as obras produzidas como resultado, esta tabela está anexada ao final do trabalho.

Com o crescente estudo dos processos de colaborações, foi possível identificar níveis de interação e como esse procedimento pode ser melhor encorajado. Utilizando as referências teóricas, definimos qual nível se enquadra a colaboração destacada na pesquisa e quais foram os caminhos adotados tanto pelo compositor como pelo intérprete para o resultado obtido. Autores como: Oskar Kroll (1965) Pamela Weston (1971), F. Geoffrey Rendall (1971), Kurt Birsak (1991), Albert R. Rice (1992), David Pino (1998), O. Lee Gibson (1998), Colin Lawson (2000), Arnold Myers (2007) e Eric Hoeprich (2008), contribuíram na organização das colaborações na história da clarineta. Para a classificação 
e apontamentos sobre o processo de colaboração utilizamos os trabalhos dos autores: John Steiner (2000), Hayden e Windsor (2007), Domenici (2016) e Cardassi e Bertissolo (2019).

$\mathrm{Na}$ segunda parte da Dissertação adotamos a pesquisa-ação como base do desenvolvimento do processo. David Tripp (2005) entende a pesquisa-ação como:

qualquer processo que siga um ciclo no qual se aprimora a prática pela oscilação sistemática entre agir no campo da prática e investigar a respeito dela. Planeja-se, implementa-se, descreve-se e avalia-se uma mudança para a melhora de sua prática, aprendendo mais no decorrer do processo, tanto a respeito da prática quanto da própria investigação (Tripp, 2005, p. 466467).

O diagrama a seguir, representa as quatro fases do ciclo básico de investiga-ação, que pode ser também interpretado como um modelo em espiral:

Figura 1 - Os ciclos da pesquisa-ação

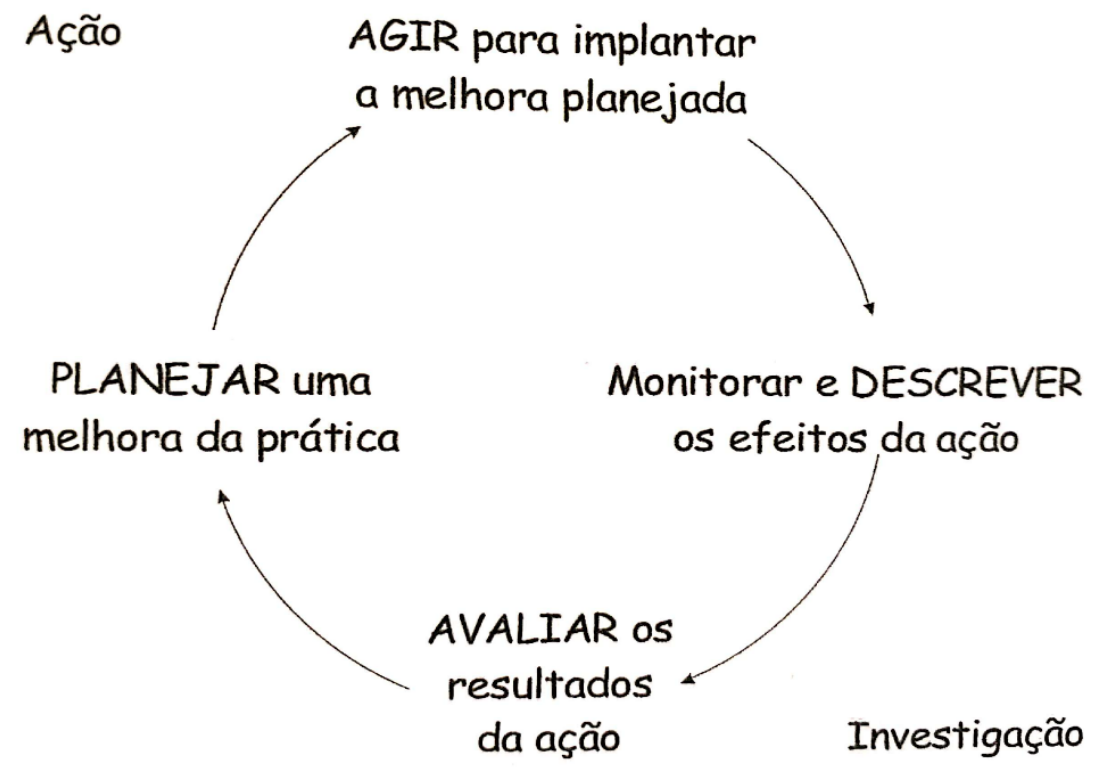

Fonte: Adaptado de RIPP, 2005, p. 446

Antes de iniciar a parte prática do capítulo, realizamos uma contextualização do Concerto e apresentamos a divisão do material musical e suas referências. A metodologia aplicada ao processo de aquisição de competências necessárias para a performance foi o Método Contextual Interference Effect (CIE), sistematizado por Silva (2016), que nos apresenta opções de Interferências do contexto, tanto no âmbito musical, quanto nas rotinas 
de estudo. Abordagem técnico interpretativa, classificando os problemas, bem como os procedimentos adotados no processo da aquisição de novas competências, também estão relatadas e toda metodologia aplicada contou com o ciclo da pesquisa-ação como referência em seu desenvolvimento.

Realizamos uma performance do Concerto, como resultado prático e aplicamos todo o processo desenvolvido neste trabalho. Sendo ainda disponibilizado, ao final deste trabalho, a gravação do concerto no formato audiovisual.

Nos anexos a esta dissertação, disponibilizamos uma fotocópia da partitura utilizada pelo pesquisador com todas as anotações que foram pertinentes para a performance e um plano de trabalho do processo de preparação.

Os objetivos desta pesquisa foram: identificar as colaborações na história da clarineta, classificar e descrever o processo de colaboração entre o compositor Magnus Lindberg e o clarinetistas Kari Kriikku, realizar uma abordagem técnico interpretativa, fazendo uma reflexão sobre as habilidades inerentes do intérprete colaborador e suas influências na escrita do Concerto, com o objetivo de apontar caminhos e soluções tanto para o repertório estudado quando para outras obras do repertório contemporâneo e realizamos uma concerto como solista interpretando o Concerto para Clarineta como resultado de todo o processo.

\subsection{DESENVOLVIMENTO IDIOMÁTICO² NA CLARINETA}

A Clarineta, no decorrer de sua existência, teve sua linguagem idiomática estabelecida, influenciada e aprimorada com base nas mais diversas situações e de variadas origens: linguagem sonora como imitação da natureza; entonação análoga à linguagem oral, (Rice, 1992); busca por uma clareza nas articulações; desenvolvimentos técnicos na construção do instrumento, (Rendall, 1971); influência das qualidades sonoras naturais do instrumento (flexibilidade, expressividade, agilidade e riqueza sonora); aprimoramento do repertório, (ReesDavies, 1995); busca de possíveis soluções para propostas composicionais inovadoras, (Rehfeldt, 1994) ; uma melhor execução das grafias musicais propostas, (Raasakka, 2009); existência de intérpretes-compositores; bem como a não menos importante relação entre

\footnotetext{
${ }^{2} \mathrm{Na}$ música, o que identifica idiomatismo em uma obra é a utilização das condições particulares do meio de expressão para o qual ela é escrita (instrumento/s, voz/es, multimídia ou conjuntos mistos). As condições oferecidas por um veículo incluem aspectos como: timbre, registro, articulação, afinação e expressão. Quanto mais uma obra explora aspectos que são peculiares de um determinado instrumento, utilizando recursos que o identificam e o diferenciam de outros meios, mais idiomática ela se torna (Menezes, 2010, p. 2).
} 
compositor-intérprete, (Weston, 1971), colaborações estas que favoreceram muito a solidificação desta linguagem idiomática do instrumento.

A necessidade de se obter uma relação mais exata entre o objeto figural e o sonoro, conseguindo, assim, que o som idealizado seja reproduzido fielmente, favoreceu o surgimento de tratados, teses, estudos, desde muito cedo na História da Música instrumental. Essa literatura facilita a compreensão da intenção musical de um compositor, de uma determinada época e estilo ou até mesmo para uma melhor utilização dos instrumentos, com a finalidade de auxiliar a realização e a interpretação da intenção original. A existência destes trabalhos é de grande importância, ainda que, em algumas situações, podem não ser suficientes no que diz respeito ao resultado sonoro; por isso, esta comunicação colaborativa entre o compositor e intérprete é primordial. Sobre a interação entre compositor e intérprete ao longo da história, Garbosa (2002),

Sempre houve na história da música, compositores-intérpretes, intérpretescompositores e compositores que trabalhavam com o auxílio dos intérpretes, visando o uso adequado das potencialidades dos instrumentos e seus recursos técnicos, objetivando estabelecer uma escrita idiomática para o instrumento e muitas vezes, dedicando-lhes as obras (Garbosa, 2002, p.19-20).

$\mathrm{Na}$ história da clarineta essa relação dinâmica favoreceu o desenvolvimento de um repertório qualificado, desenvolvimento de técnicas estendidas e colaborou com a sua evolução mecânica. A criação de novas formas musicais, ousadia na escrita, brilhantismo e virtuosidade exigidos por novos estilos, obrigou os clarinetistas a realizarem verdadeiras proezas com o instrumento. desenvolver um instrumento ágil, de sonoridade homogênea e com melhor resposta na execução das ideias composicionais. Ressaltamos também a importância do clarinetista/compositor e do clarinetista/construtor na evolução histórica do repertório e do instrumento.

\subsection{A COLABORAÇÃO ENTRE COMPOSITORES E INTÉRPRETES NA HISTÓRIA DA CLARINETA}

Alguns trabalhos teóricos nos auxiliam na catalogação das obras compostas a partir da interação entre compositores e intérpretes e apresentam exemplos da cronologia da elaboração das obras e suas estreias ao público. Podemos citar os trabalhos Players and composers $^{3} \mathrm{da}$

\footnotetext{
${ }^{3}$ WESTON, Pamela. Playes and composers. In: LAWSON, Colin. The Cambridge Companion to the clarinet. Cambridge: Cambridge University, 1995, p. 92-106.
} 
Prof ${ }^{a}$. Dra. Pamela Weston em que nos apresenta uma detalhada ordem cronológica da concepção das obras e também faz uma catalogação de como esta interação se estendeu para outros estilos de composição como a ópera e a música sinfônica e a Dissertação de mestrado de Nuno Fernandes Pinto com o Tema: A influência dos clarinetistas no desenvolvimento do clarinete e do seu repertório ${ }^{4}$ trabalho este apresentado para obtenção do título de mestre pela Universidade de Aveiro - Portugal.

Além dos trabalhos acima mencionados compreendemos que o conhecimento idiomático desenvolvido pelo instrumentista é uma ferramenta que agrega o domínio de algumas especificidade que auxiliam na produção de compositores que também são clarinetistas, destacamos alguns nomes que colaboraram com o desenvolvimento da escrita para o instrumento: George Fuchs (1752-1821), Franz Tausch (1762-1817), Charles Duvernoy (17661845) Andreas Goepfert (1768-1818), Bernhard Henrick Crussel (1775-1838), Jean Xavier Lefévre (1778-1829), Jacques-Jules Bouffil (1783-1868), Heinrich Baermann (1784-1847), Iwan Muller (1786-1854), Christian Rummel (1787-1849), Ernesto Cavallini (1807-1874), Hyancinthe Klosé (1808-1880), Louis Cahuzac (1880-1960), William O. Smith (1926 -), Bela Kovacs (1937-), Jorg Widman (1973-), Luca Raele (1962-), dentre outros.

Ressaltamos ainda que o repertório da clarineta esteve diretamente ligado à evolução mecânica do instrumento e tais modificações contribuiram para a escrita dos compositores de maneira muito expressiva. Nesse sentido, destacamos aqui os trabalhos de Oskar Kroll (1965) Pamela Weston (1971), F. Geoffrey Rendall (1971), Anthony Baines (1991), Kurt Birsak (1991), Albert R. Rice (1992), David Pino (1998), O. Lee Gibson (1998), Colin Lawson (2000), Arnold Myers (2007) e Eric Hoeprich (2008).

Essas pesquisas nos fornecem informações sobre a colaboração entre compositores e intérpretes, evidenciando assim como essa interação atuou na formação de um repertório sofisticado e com um número expressivo de obras. O intercâmbio de informações entre as partes proporcionou, possivelmente, muitos questionamentos a respeito da linguagem escrita e sua correspondência sonora. Estes questionamentos acabaram provocando e ainda provocam inquietudes, na tentativa de suas resoluções, levando a reflexões sobre temas como: a conquista de novos repertórios, descobertas de novos sons e efeitos, desenvolvimento técnico e aprimoramento na sensibilidade de como lidar com o instrumento, a gestualidade sonora na

\footnotetext{
${ }^{4}$ PINTO, Nuno Fernandes. A influência dos clarinetistas no desenvolvimento do clarinete e do seu repertório. 2006. Dissertação (Mestrado em Música) - Universidade de Aveiro, Departamento de Comunicação e Artes, Aveiro, 2006.
} 
escrita e o uso do corpo na execução do instrumento, entre outros. Consequentemente, tais atitudes transformaram essa busca conjunta pelo entendimento das possíveis linguagens de expressão musical em uma ferramenta atuante no aperfeiçoamento da dialética do instrumento.

As informações coletadas dos trabalhos já citados anteriormente, gerou uma tabela com algumas das principais colaborações ao longo da história do instrumento, este material se encontra no apêndice A.

\subsection{REFERÊNCIAS NO ESTUDO DA COLABORAÇÃO}

Analisando a definição de Hayden and Windsor (apud Cardassi e Bertissolo, 2019), a interação artística se organiza em três grupos:

1) diretivas: onde o compositor coloca as informações na partitura e não há contato com os músicos; 2) interativa: quando existe relativa interação, onde compositor e performer se encontram para discutir trechos que podem ser melhorados, seja em interpretação quanto em notação, e 3) colaborativa; onde os participantes do processo estão abertos a relativizar seus papéis criativos, mostrando-se menos fechados em suas áreas específicas (sem ignorá-las), mas promovendo um processo mais participativo (Cardassi e Bertissolo, 2019, p.7).

Estas definições contribuem para uma organização do processo de trabalho entre compositores e performers e foram utilizadas como ferramenta na classificação da colaboração investigada neste trabalho. O material utilizado para a coleta das informações referentes ao processo de colaboração, foram entrevistas concedida pelo compositor, sendo uma no dia 28 de novembro de $2012^{5}$, para o projeto "Música na Cabeça", programa desenvolvido pela Orquestra Sinfônica do Estado de São Paulo - OSESP e a outra para a Orquestra Metropolitana, referente ao concerto realizado no dia 20 de maio de $2018^{6}$. Cruzando os relatos obtidos nas duas entrevistas, Magnus Lindberg relata que: depois de 6 meses trabalhando no Concerto e após uma primeira leitura com Kari Kriikku, foi necessário realizar diversas alterações na obra. Segundo o compositor, o performer sugeriu diversas mudanças no material apresentado até então, não buscando facilitar o concerto, mas sim, com o objetivo de compartilhar as possibilidades idiomáticas do instrumento e obter uma maior eficiência na realização das idéias do compositor. Após o primeiro encontro ficou evidenciado, segundo Lindberg, a necessidade de um diálogo constante com o instrumentista. Sendo assim, conversas diárias foram realizadas

\footnotetext{
${ }^{5}$ Disponível em: https://www.youtube.com/watch?v=HW6aOevetuM. Acesso em: 19 ago. 2018.

${ }^{6}$ Disponível em: https://www.youtube.com/watch?v=-9k1W-ImYDY. Acesso em: 19 ago. 2018.
} 
e com isso o processo de composição não precisaria ser totalmente revisto após longos períodos de trabalho.

O compositor enfatiza que o intérprete não compôs o concerto, mas o auxiliou, demonstrando possibilidades que seriam mais eficazes no instrumento. $O$ processo de colaboração relatado pelo compositor tem sido objeto de estudo de recentes pesquisas, algumas referências nos mostram que alcançar um nível profundo de colaboração é mais raro, requer mais tempo e uma troca mais corajosa entre os participantes. Um dos pontos cruciais do processo colaborativo entre compositor e performer reside no que a pesquisadora John-Steiner (2000) chama de paradoxo da colaboração:

Existe um profundo paradoxo na colaboração produtiva. As capacidades de cada indivíduo são aprofundadas enquanto descobrem os benefícios da reciprocidade... para isto é preciso tempo e esforço. Envolve a criação de uma linguagem compartilhada, os prazeres e riscos de um diálogo honesto e a busca por um terreno comum. Em atividades colaborativas nós aprendemos uns com os outros, nós nos envolvemos em apropriação mútua, nós nos vemos através dos olhos dos outros e, com seu apoio, podemos explorar novas partes de nós mesmos. Quando nos juntamos a outros aceitamos seu gesto de confiança e, através de interdependência, alcançamos competência e conexão (John-Steiner, 2000, p. 204)

Quando a colaboração se distancia da "impessoalidade da relação de trabalho", (Domenici, 2010) e se aproxima da relação de reciprocidade apontada por John-Steiner, e onde têm sua relação enraizada em relações humanas de parceria e respeito mútuo, nascem projetos verdadeiramente colaborativos (Cardassi e Bertissolo, 2019).

De acordo com Alencar (1986, p.12), "todo ser humano apresenta certo grau de habilidades criativas e que essas habilidades podem ser desenvolvidas e aprimoradas por meio da prática e do treino. Para isso, são necessárias tanto as condições ambientais favoráveis, como o domínio de técnicas adequadas". Assim, e com o objetivo de compreender em momento da sua tragetória o intérprete Kari Kriikku iniciou sua atividade de colaboração com compositores, encontramos em sua biografia, referências do período que era estudante da Academia Sibelius em Helsinque - Finlândia, onde em 1983 participou juntamente com alguns professores da criação do Ensemble Toimii (que em Finlandês quer dizer "Isso funciona"), formado para ser um laboratório para compositores, instrumentistas e outros artistas, com o objetivo de descobrir novas formas de imaginar e criar música. A idéia de fundar o grupo surgiu quando Magnus Lindberg, Otto Romanowski e Esa-Pekka Salonen estavam preparando uma apresentação de concerto de Plus-Minus de Karlheinz Stockhausen. Lindberg compôs para a ocasião a peça 
Ação-Situação-Significação que foi concebida através das correspondências com Vinko Globokar e o grupo de improvisação New Phonic Art Inf. O primeiro concerto do grupo foi no Festival de Verão de Jyväskylä na Finlândia em 1982.

Além de realizar algumas obras já existentes e criar peças coletivas, o grupo incentivou poetas, pintores, dramaturgos e atores a participarem de seus concertos. O coletivo acreditava que todos os artistas criam através de um processo similar e podem, assim, comunicar-se através do trabalho uns dos outros. A proposta aplicada aos ensaios do grupo sempre foi de não ter nenhuma programação determinada e o trabalho consistia em combinar peças existentes com composições e arranjos feitos no momento de maneira improvisada. Não era utilizado nenhum tipo de hierarquia na organização do trabalho, todos os membros possuíam liberdade e autonomia para criar e participar em todos os concertos, acreditando que uma ideia é um recurso natural tão raro que, se alguém já teve uma, sempre vale a pena desenvolver ${ }^{7}$. Músicos fundadores do ensemble foram: Lassi Erkkilä, Juha Hemánus, Kari Kriikku, Anssi Karttunen, Timo Korhonen, Juhani Liimataine, Magnus Lindberg, Riku Niemi, Otto Romanowski e EsaPekka Salonen.

Examinando a experiência vivenciada pelo intérprete, durante os anos de participação no Ensemble Tomii, compreendemos de que maneira o performer desenvolveu um diálogo aberto com diversos compositores. Além de Magnus Lindberg podemos citar: Vinko Globokar, Kaija Saariaho, Jukka Tiensuu, Jouni Kaipainen, Kimmo Hakola, Esa-Pekka Salonen, Pawel Szymanski, Eero Hämeenni Kosemeenni e Usko Meriläinen, e o resultado dessas colaborações é a formação de um repertório com obras de câmara e concertos. Este repertório está registrado em gravações premiadas, como é o caso do Concerto para clarineta (2002) de Magnus Lindberg, que recebeu os prêmios, BBC Music Magazine's Award e o Gramophone Award. Segundo o levantamento realizado, o intérprete não se limita somente as estreias e gravações das obras, mas realiza um trabalho de divulgação deste repertório, como exemplo é a execução de mais de 40 vezes do Concerto Puro e a Missa do compositor Jukka Tiensuu ${ }^{8}$. Atualmente além de exercer a atividade de solista internacional, Kari Kriikku é desde 1998, diretor artístico da Orquestra de Câmara Avant! projeto que atua na performance de obras contemporânea e na reflexão sobre o ritual do concerto convencional.

\footnotetext{
7 THE legendary TOIMII Ensemble. Karttunen, 2019. Disponível em: http://www.karttunen.org/home.html/Toimii.html. Acesso em: 2 jun. 2019.

${ }^{8}$ Disponível em: https://www.ondine.net/index.php?lid=en\&cid=3.2\&oid=527. Acesso em: 19 ago. 2018.
} 
Como observado, a interação entre compositores e performers pode se desenvolver por conta de algumas circunstâncias em que o relacionamento é estimulado, e uma dessas situações é a criação de ambientes favoráveis ao diálogo e a troca de experiências entre eles (Cardassi e Bertissolo, 2019). O intérprete oferece o conhecimento das possibilidades idiomáticas e provoca reflexões a respeito de técnicas e sonoridades que é um conhecimento prático da execução. A criação de ambientes que estimulem o diálogo aberto e a troca de experiências, favorecem a produção de novas obras, pois "compositores e intérpretes aprendem pela convivência em um território que é, por natureza, do outro" (Ray, 2010, p. 1310-1314). Essa relação, que não é nova, como já vimos na bibliografia consultada, colabora tanto com o surgimento de novas obras, como para a expansão da técnica da clarineta.

Destacamos que na Escola de Comunicação e Artes - CMU - USP, existe a disciplina denominada Criação e Performance no Repertório Musical Contemporâneo I e II, que realiza a mesma atividade proposta pelo Tomiie Ensemble, integrando alunos de composição com os instrumentista, propondo uma atividade colaborativa, onde o diálogo aberto é estimulado e que cooperou com a aplicação dos processo de colaboração aqui apresentados. Como resultado deste trabalho foram estreadas as peças: Construção II (2018) de Sergio Karfejian e Lyapunov time (2019) de Luzilei Aliel. 


\section{CONCERTO PARA CLARINETA E ORQUESTRA DE MAGNUS LINDBERG}

A escolha do concerto como objeto prático deste trabalho, se deu, por ser o resultado de um processo "efetivamente colaborativo" (Hayden and Windsor, 2007), em sua concepção. Lindberg relata que sem o auxílio do intérprete, não teria obtido os mesmos resultados na elaboração do concerto. Como discutido anteriormente, a responsabilidade do intérprete em cooperar para uma escrita mais idiomática, não significa facilitar o material musical, mas empregar o seu conhecimento prático na otimização das ideias do compositor e demonstrar possibilidades sonoras inerentes ao seu tempo, formação, ideologias e repertório cultural. Reconhecido por seu trabalho na música contemporâneo, Kari Kriikku demonstra destreza em efeitos como overtones, glissandos de harmônicos, staccatos duplos e triplos, superagudos utilizando o dente na palheta e multifônicos, além da fluência no manuseio da região aguda do instrumento. Estas habilidades foram exploradas na escrita do concerto e como resultado produziu-se uma obra com alto grau de dificuldade, que demanda uma abordagem diferente da utilizada no repertório tradicional. Segundo Afonso (2006):

A performance do repertório de música contemporânea possui distinções perante outros repertórios em aspectos como: extrema complexidade, dificuldades técnicas e concepção interpretativa não usuais às obras de repertório tradicional (Afonso, 2006, p. 28).

Considerando que a difusão do processo de aquisição das habilidades, necessárias para a performance, pode cooperar com a acessibilidade do repertório desenvolvido em colaboração e compreendendo que certas habilidades são intrínsecas ao intérprete colaborador. Acreditamos que a abordagem realizada na perspectiva de outro intérprete possa gerar ferramentas que auxiliem outros pesquisadores na performance tanto do Concerto quanto de outras obras contemporâneas. A performance do concerto é parte importante deste trabalho, pois somente na situação da performance, foi possível avaliar o resultado do trabalho.

\subsection{CONTEXTUALIZAÇÃO}

O Concerto para Clarinete de Magnus Lindberg foi encomendado entre os anos 2001/2002, pela Finnish Broadcasting Company para o 75ª aniversário da Orquestra Sinfônica da Rádio Finlandesa, Orquestra Filarmônica Real de Stockholm, Stockholm Concert Hall Foundation e Radio France. Foi estreado em 14 de setembro de 2002 em Helsinque com a 
Orquestra Sinfônica da Rádio Finlandesa, conduzido por Jukka-Pekka Saraste. Gravação lançado pelo selo Ondine Records em julho de 2005 com a Orquestra Sinfônica da Rádio Finlandesa, conduzida por Sakari Oramo. Editora: Boosey \& Hawkes.

Segundo Lindberg:

Eu escrevi o Concerto para clarineta para o Kari Kriikku, a quem eu conheço desde o final dos anos 1970: ele estudou harmonia comigo na Academia Sibelius. Então, depois de 25 anos trabalhando juntos, eu acho que nós desenvolvemos um bom entendimento e eu não poderia ter escrito sem ele. Durante o verão, eu trabalho na minha casa de campo em uma ilha no Golfo da Finlândia: a casa é da minha família desde de 1830 e é onde eu cresci. Kari Kriikku vive nos arredores de Helsinque e embora eu poderia dirigir até a casa dele, é muito mais fácil pegar o barco. Então, cada parte escrita do concerto terminou com uma recriação maravilhosa, uma viagem de barco! Foi uma perfeita recompensa. O Concerto para clarineta é um grande trabalho, não em duração, mas em escala. As primeiras palavras que Kari me disse foram "Escreva algo fortississimo para a orquestra, mas permita que o clarinete seja ouvido!" Muitas vezes em novas músicas, as pessoas têm medo de colocar o instrumento solista contra uma orquestra com o volume bem alto. Mas nós fizemos isso! De todas as minhas obras, o Concerto para Clarineta é um que eu ainda tenho muito carinho?.

O concerto, segundo Morell (2014, p. 47), em termos de música finlandesa e o legado de Sibelius, pode ser resumido com os seguintes termos:

a) desenvolvimento contínuo;

b) cristalização temática;

c) gênese teleológica.

Em resumo, um tema é apresentado inicialmente de forma incompleta ou imatura. Com cada recorrência, cresce em complexidade, duração etc. O tema só é totalmente constituído (cristalização) com a sua última apresentação ou em um ponto culminante de chegada dramática - clímax - no final da peça. Todo o trabalho é levado a essa revelação: o "nascimento" do tema, ainda não totalmente formado, que tem sido descrito como gênese teleológico: todos os eventos anteriores e apresentações temáticas levam a música para um objetivo final.

\footnotetext{
${ }^{9}$ MAGNUS Lindberg Clarinet Concerto. Kari Kriikku Clarinettist, 2019. Disponível em: http://www.karikriikku.com/?page id=287. Acesso em: 2 jun. 2019.
} 
O material motívico de abertura retorna ao longo de toda a peça, às vezes ligeiramente alterada; não é como um tema do período romântico com temáticas múltiplas e diferentes ideias. Como resultado, as seções de um concerto de um movimento contínuo podem ser mais difíceis de identificar que uma obra com movimentos claramente definidos, porque todo o concerto de um movimento é atrelado de maneiras sutis. Segundo Litter (2018), essa continuidade no concerto de Lindberg se deve ao fato de que:

a) Existe um elemento de fluxo contínuo no material, que é linear e faz uso de transições suaves - muitas vezes em primeiro plano (ou seja, a linha do clarinete)

b) Há outro elemento, num plano de fundo, que usa um bloco descontínuo de materiais, que não estão relacionados e não têm qualquer tipo de transição entre eles (ou seja, dentro da orquestra)

c) O uso desses dois elementos simultaneamente resulta em um efeito pelo qual a música é contínuo e descontínuo em duas camadas - alternando entre o primeiro plano e uso em segundo plano. Isso cria duas dimensões da experiência auditiva que coexistem no diálogo e na competição - solista e orquestra. (LITTER, 2018, p. 34, tradução nossa.)

O "segundo motivo" é visto pela primeira vez no compasso 34 e é contrastante com o motivo lírico da abertura, com um material sonoro mais energético. Seguindo o "segundo motivo" que é apresentado em forma de tercinas, esta figura rítmica é aumentadas ou diminuídas ao longo da obra.

Embora o concerto tenha somente um movimento contínuo, estudos apontam a existência de 6 seções distintas, e que algumas citações a obras de outros compositores são recorrentes durante a composição. Destacamos as referências com base em impressões obtidas pela audição e estudo da obra aos compositores: Mozart, Ravel, Debussy e Gershwin.

\section{Seções:}

Seção 1: O concerto inicia com um simples motivo que se repete e se desenvolve durante todo o trabalho. A orquestra executa algumas variações harmônicas e rítmicas baseadas na melodia da abertura, vale ressaltar que o intervalo inicial é o mesmo encontrado no Concerto para clarinete Orquestra, KWV 622 de W.A.Mozart. 
Figura 2 - Compassos 1-10
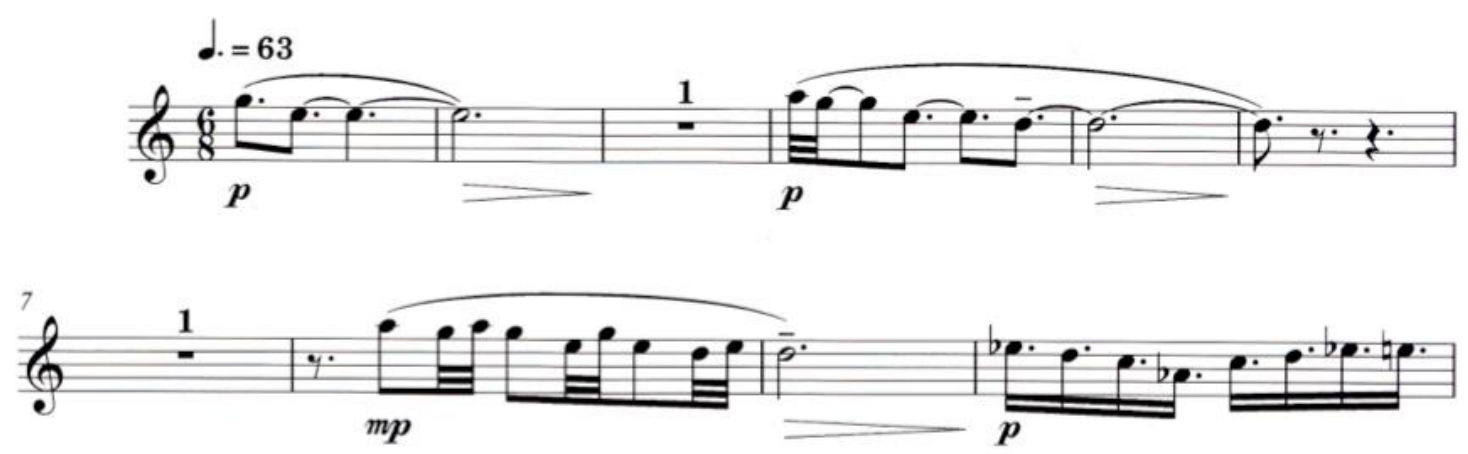

Fonte: LINDBERG, 2013, p. 1

Seção 2: Neste trecho notamos uma citação a obra Daphnis et Chloé de Maurice Ravel, o mesmo gesto musical presente no concerto é encontrado entre os números de ensaio 155 ao 169, da obra. Este mesmo motivo se repete depois para toda a orquestra em outros momentos do concerto.

Figura 3 - Compassos 75-77

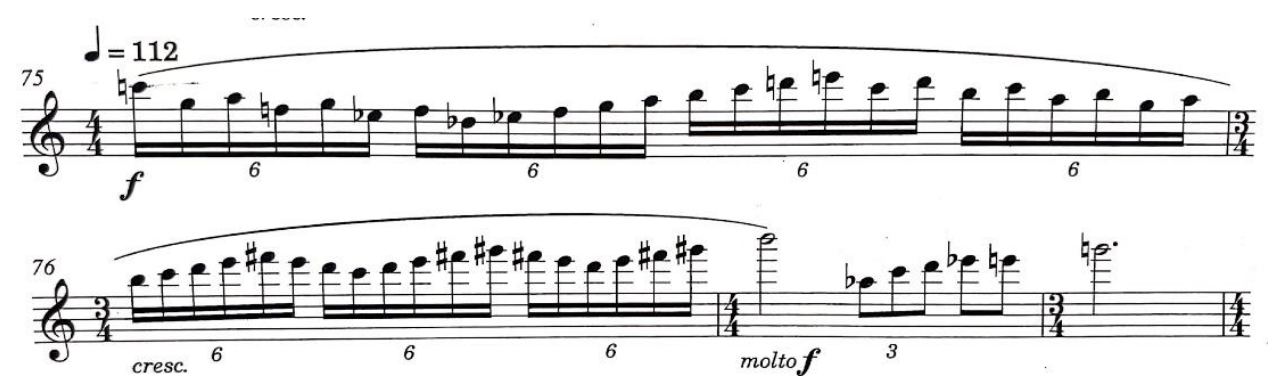

Fonte: LINDBERG, 2013, p. 3

Seção 3 Esta seção, mais lenta, começa com uma passagem para o solista que remete aos compassos 46 e 167, da Primeira Rhapsodie de Debussy (1910), que define o humor adotado por um longo trecho da obra. 
Figura 4 - Compassos 84-94

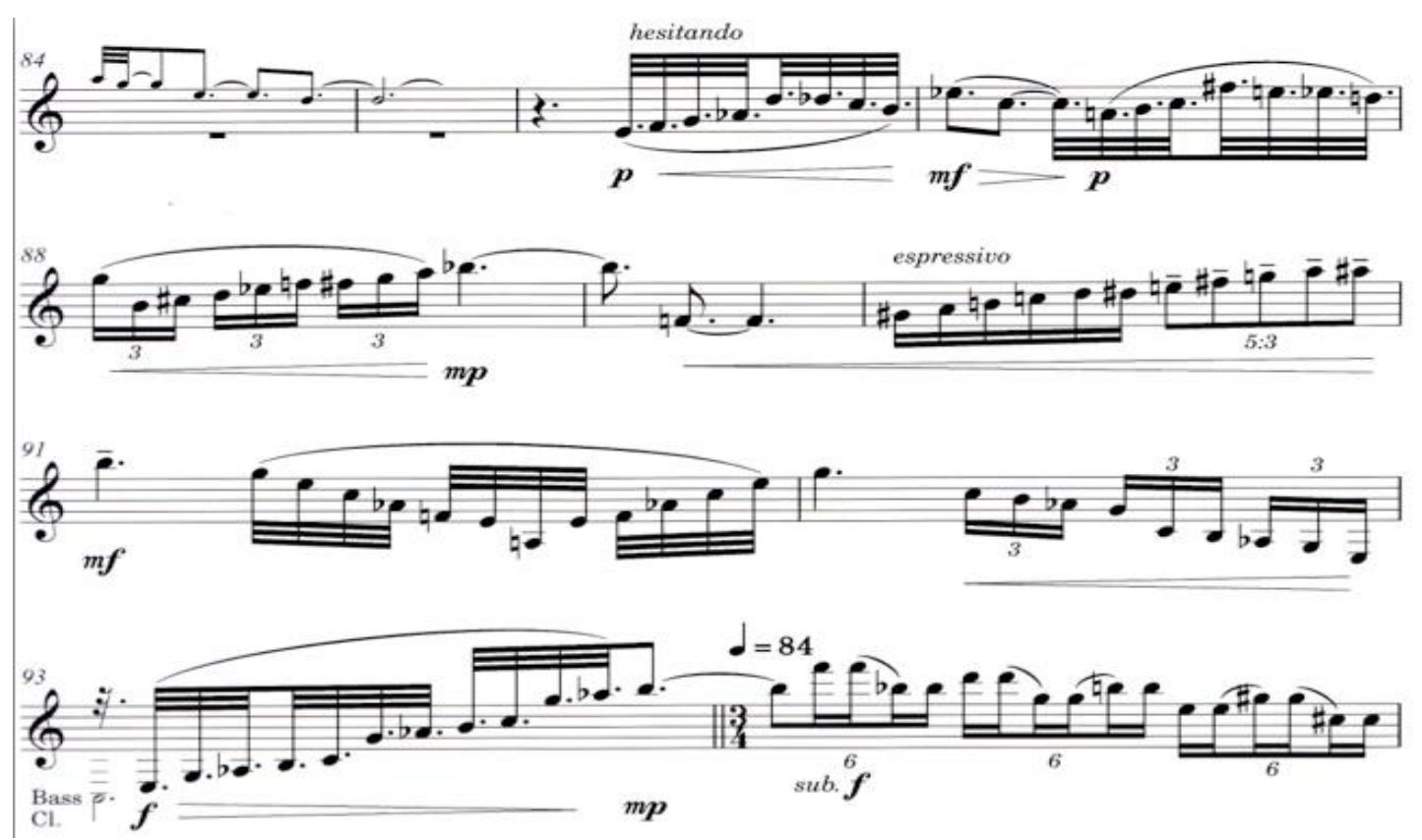

Fonte: LINDBERG, 2013, p. 4

Seção 4: começando no compasso 269, o clarinetista cria uma atmosfera de dança e constrói um clímax orquestral de grande densidade e volume, que é direcionado ao compasso 411.

Figura 5 - Compassos 268-274
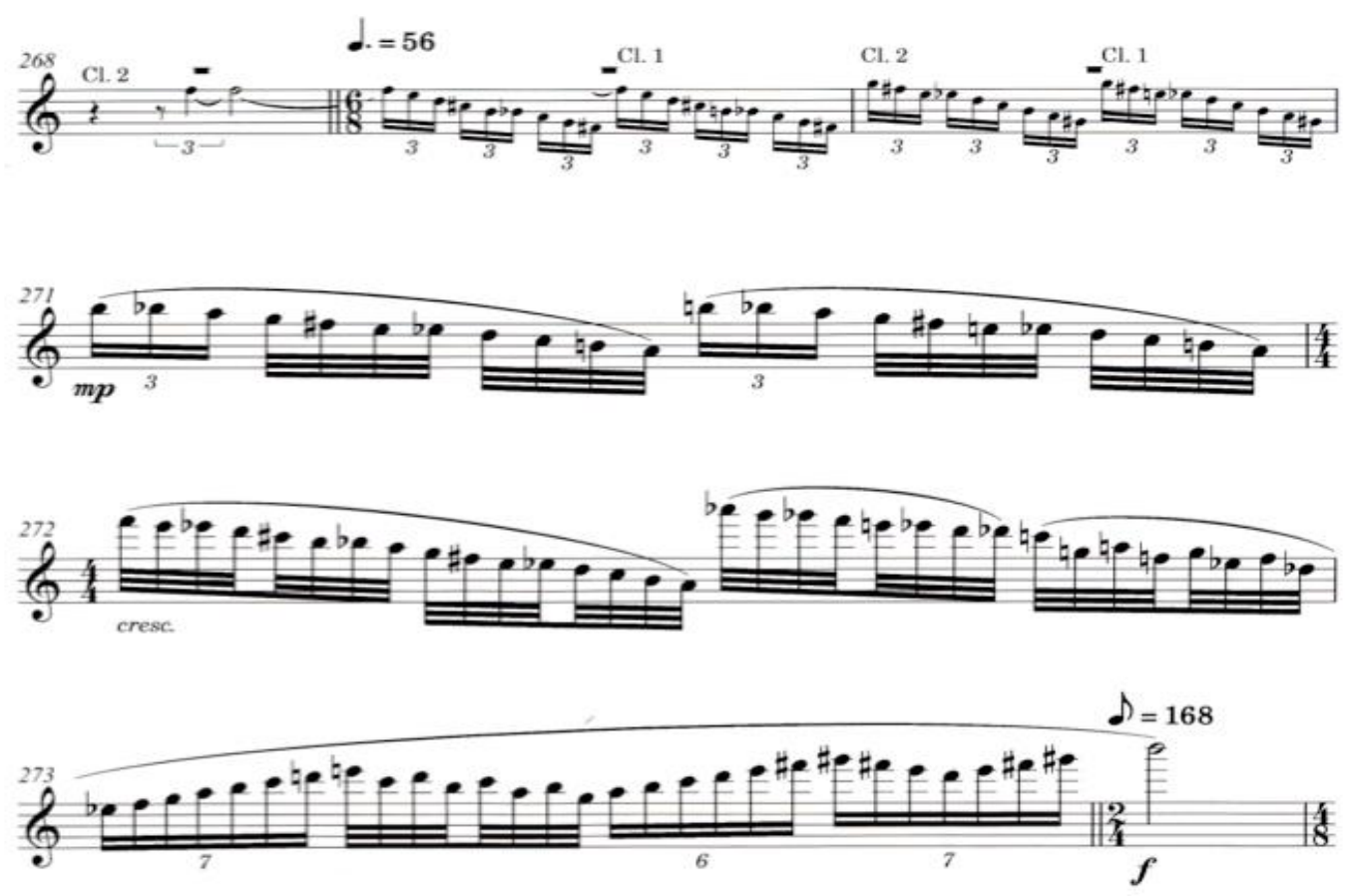

Fonte: LINDBERG, 2013, p. 12 
Seção 5: "Lindberg observa que um dos pedidos de Kriikku para a peça, era que o clarinete ocasionalmente pode ser colocado contra fortíssimos orquestral. Esta longa seção é marcada por uma série de diálogos entre o solista e vários outros instrumentos, levando a uma cadência complexa" 10

Figura 6 - Compassos 376-383 (retorno do motivo temático original para construir a cadência)
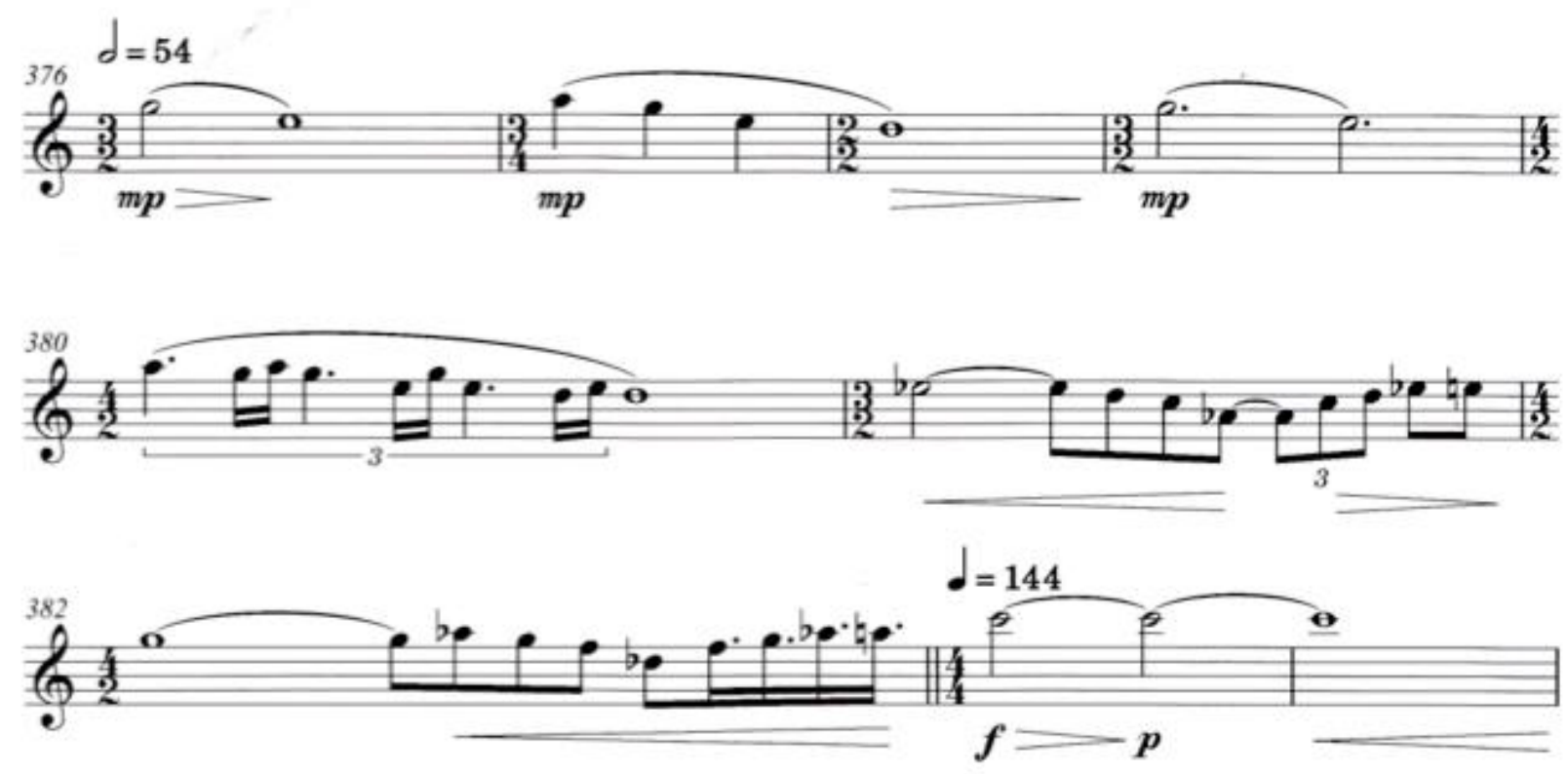

Fonte: LINDBERG, 2013, p. 16

Seção 6: "Jazzy". A seção final começa no compasso 558 com um cenário jazzístico que aumenta em intensidade para estabelecer a conclusão climática. A melodia do clarinete retorna depois de um longo descanso, acompanhado pela orquestra e prossegue com um glissando no compasso 659, que vai da região do chalumeau até a região aguda do instrumento, este glissando nos remete ao primeiro compasso da Rhapsody in Blue de George Gershwin. A obra termina em um grande acorde com o clarinete tocando a nota mais grave e desvanecendo-se em um pianíssimo.

\footnotetext{
${ }^{10}$ HOSFIELD, Patrick. Music at The Mission: night ferry. Cabrillo Music, 2017. Disponível em: http://www.cabrillomusic.org/index.php?option=com_content\&id=719/?s=2013. Acesso em: 2 jun. 2017.
} 
Figura 7 - Compassos - 558-570
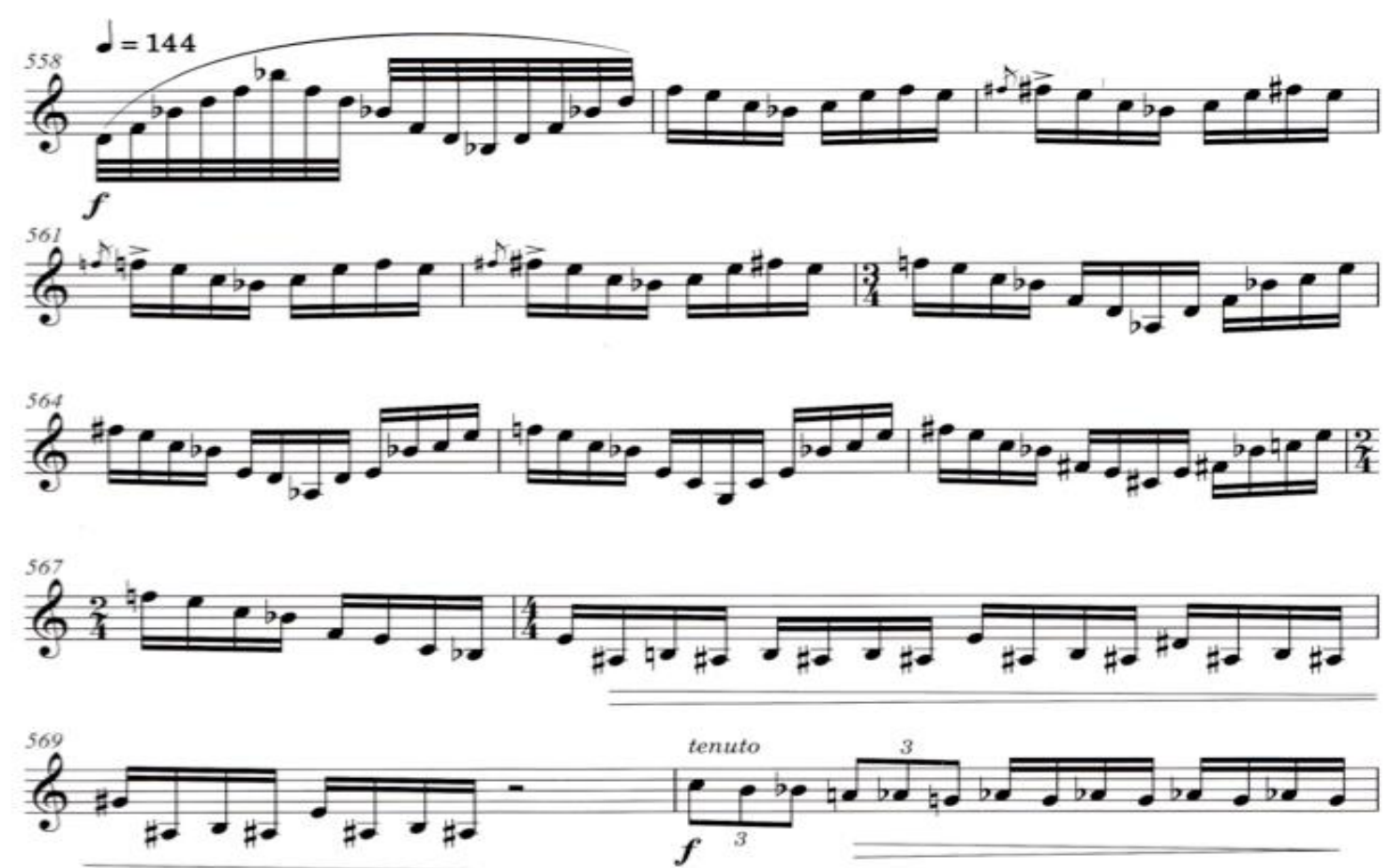

Fonte: LINDBERG, 2013, p. 24

Figura 8 - Compassos 659 até o fim

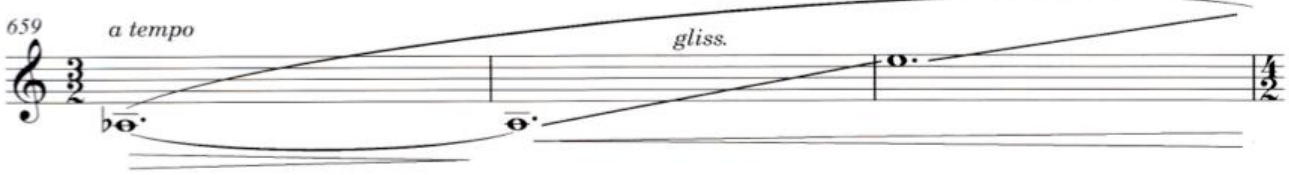

rallentando
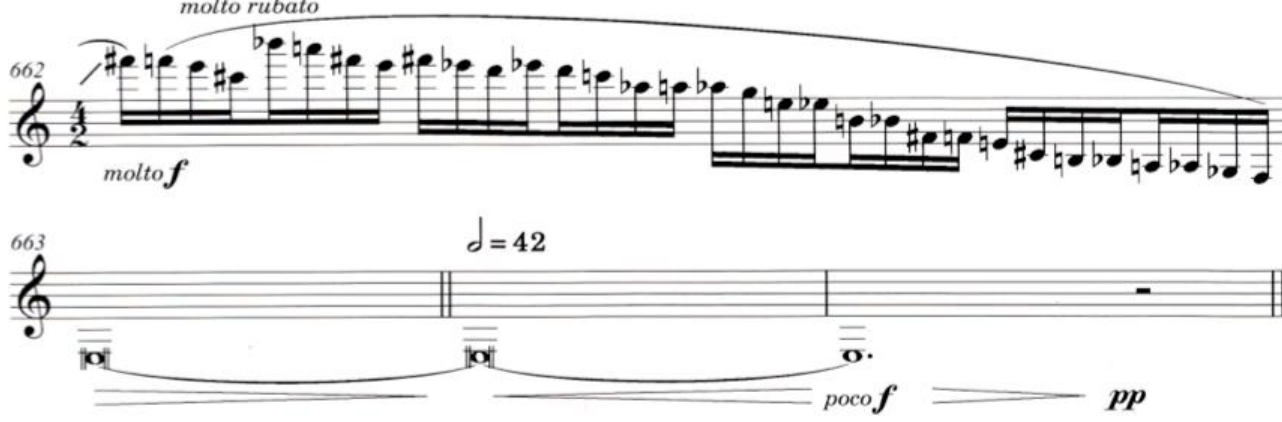

Fonte: LINDBERG, 2013, p. 28 


\subsection{ABORDAGEM TÉCNICO-INTERPRETATIVA}

Não se pode negar que a interpretação implica em decisões - conscientes ou não - a respeito das funções contextuais de certos aspectos musicais e dos meios de projetá-los. Até mesmo a passagem mais simples - uma escala ou uma cadência perfeita, por exemplo - será moldada de acordo com a compreensão do intérprete, de como esta se encaixa numa obra em particular e as prerrogativas expressivas com que ela ou ele se dedicam. Tais decisões podem, sem problemas, ser intuitivas e não sistemáticas, mas não necessariamente: muitos intérpretes refletem cuidadosamente sobre como a música funciona" e sobre os meios de superar seus vários desafios conceituais. (Rink, 2002, p. 35, tradução de Zélia Chueke).

Para uma abordagem técnico-interpretativa do concerto, decidimos adotar algumas estratégias que sistematizaram o estudo, para assim obter um melhor aproveitamento das propostas musicais do compositor. O estudo consciente e reflexivo foi estimulado, para que os resultados obtidos colaborassem com uma interpretação consciente e uma performance de qualidade.

Neste processo, alguns fatores contribuíram para um melhor aprendizado, tais como:

a) análise e classificação dos possíveis problemas técnicos;

b) estudos dirigidos e o uso do senso crítico para a avaliação dos resultados;

c) anotações de todo o processo de estudo, classificando como os problemas foram resolvidos e a metodologia aplicada;

d) realização de pesquisa com diferentes dedilhados com o objetivo de facilitar o gesto musical;

e) desenvolvimento de resistência física e mental;

f) estudo e pesquisa de novos materiais (boquilhas, palhetas, braçadeira e instrumento) na busca de uma maior amplitude do volume sonoro do instrumento;

g) utilização de estratégias de estudo através da aplicação do método Contextual interference effect;

h) conduzir a atividade mental do aprendizado inicial a um produto final. 


\subsection{PROCESSO DE ESTUDO}

Uma preocupação recente na atuação da música como atividade performativa é a investigação e análise de métodos de trabalho, que resultem numa forma mais produtiva e proveitosa no processo do estudo do instrumento (Kageyama, 2010; Hyllegard e Bories, 2008; Nielsen, 2001; Ericsson, Krampe e Tesch-Romer, 1993; Johnston, 2002; Williamonn, 2004). As técnicas de estudo tradicionalmente utilizadas são baseadas sobretudo, na repetição, onde o processo se inicia em um andamento lento e vai acelerando gradativamente até atingir a velocidade proposta pelo texto musical, também conhecido como estudo bloqueado, uma vez que não a variação ou alteração do contexto presente no material estudado, (Silva, 2016). Esse tipo de estudo não foiutilizado para a presenta pesquisa.

A necessidade de uma abordagem objetiva na solução dos problemas e uma análise dos resultados, nos aponta para um processo de estudo com estratégias pré estabelecidas. A primeira estratégia adotada foi a estruturação de uma planilha (apêndice B) com a data do concerto como ponto de chegada do processo. Depois, identificamos alguns trechos de dificuldades que necessitavam de aquisição de novas competências e consequentemente maior atenção no processo de estudo; também realizamos um estudo para as técnicas estendidas que fossem necessárias desenvolver para a performance do concerto.

O processo não mecanizado do estudo foi aplicado em todas as dificuldades elencadas. Este padrão de estudo criativo já estava sendo estimulado há algum tempo pelo pesquisador no seu dia a dia, sendo no repertório orquestral, solo ou de música de câmara. Encontramos uma reflexão mais aprofundada, acerca da alteração tanto do objeto musical como do processo de trabalho na tese de Doutorado do Prof. Nuno Silva - A aplicação do Contextual Interference Effect (CIE) no Estudo do Repertório para Clarinete, proposta de modelos e ferramentas de trabalho. Aplicamos o modelo de trabalho sugerido e adaptamos algumas propostas para este estudo. Segundo o autor a retenção cerebral e a assimilação do conteúdo musical é acelerado quando utilizado a alteração do contexto a nível da ordem das notas, articulação e do ritmo. Para uma melhor sistematização dos vários tipos de interferência do contexto, é sugerido a seguinte classificação pelo autor (Silva, 2017, p. 74): 


\section{A) Alteração do objeto de estudo (conteúdo musical)}

1. Interferências rítmicas:

- Variação de velocidade (tempo).

- Deslocamento da nota de apoio.

- Intercalar pausas de tempo variável entre diferentes combinações de notas.

- Variação rítmica (ritmos pontuados).

2. Interferência melódica:

- Variação intervalar (inversão e permutação).

- Retrogradação das passagens.

- Combinação de diferentes passagens.

- Alterar aleatoriamente a ordem das passagens trabalhadas.

3. Interferência na articulação.

4. Interferência de dinâmica.

\section{B) Interferências relativas ao contexto de trabalho.}

- Duração das sessões de estudo.

- Quebra de rotinas.

- Interferência a nível do material usado (palhetas, instrumentos, boquilhas).

- Variação do espaço e ambiente de trabalho.

Além da classificação das possibilidades do método (CIE), o estudo apresenta modelos como aplicá-los, utilizando como exemplo musical a Première Rhapsodie pour Clarinette et Piano de Claude Debussy, alguns destes modelos foram testados e aplicados durante o processo de estudo do concerto.

Para um melhor aproveitamento das sugestões e um direcionamento do estudo no sentido da performance, destacamos 5 dificuldades, que durante a leitura do concerto se mostraram requerentes de um tempo maior de estudo. As dificuldades destacadas foram: passagens no registro agudo, trêmulos, arpejos, articulação e técnicas estendidas. Criamos mecanismos de estudos diferentes para cada uma e aplicamos as propostas do método (CIE) sugeridas, além de consultar métodos e sugerir exercícios. Descreveremos o processo de pesquisa empregado em cada dificuldade e quais as técnicas adotadas, para a aquisição das competências necessárias para execução do texto musical proposto pelo compositor. 


\subsubsection{Passagens no registro agudo}

Para o estudo dos trechos musicais com notas agudas, utilizamos o método "Etude des harmoniques et das Suraigu" do Clarinetista Francês Joseph Marchi (2010) e o trabalho de Alan C. Sim, "Clarinet Fingerings" (1991). Estes trabalhos se mostraram fundamentais na escolha de dedilhados que possibilitaram uma digitação simples e fluente. Importante ressaltar que as propriedades acústicas da clarineta, oferecem diversos dedilhados para a mesma nota, o que colaborou de maneira conveniente para a pesquisa. As escolhas dos dedilhados para a realização das notas, foram pautadas na necessidade de cada trecho musical. Quando o trecho exigia um gesto musical rápido, optamos por posições mais simples e que apresentassem uma economia de movimento. A afinação de cada nota não se mostrou muito precisa, mas notamos que isso não prejudicava o discurso musical. Já nos trechos em que eram exigidas notas agudas com grande volume sonoro e afinação precisa, outras opções foram utilizadas, privilegiando a ressonância, o timbre e a afinação.

Durante o aprendizado, um cuidado maior foi dado ao uso da embocadura e das possibilidades de ajustes de micro-afinação na utilização de maior ou menor pressão dos lábios na palheta. Para este estudo foi utilizado o programa Tunable, que é instalado no celular na forma de aplicativo. Este programa é um afinador digital utilizado para a verificação da afinação da nota executada. Esta ferramenta colaborou no processo do desenvolvimento de uma memória muscular e auditiva e se mostrando eficaz nos momentos em que o concerto exigia uma afinação precisa.

Acusticamente a clarineta é definida como um instrumento de tubo cilíndrico fechado. Essa característica acarreta, segundo Benade (1990), em um número quatro vezes maior de ondas dentro do tubo e Roederer (1998, p. 192) acrescenta que "a altura fundamental de uma nota tocada numa clarineta está realmente uma oitava abaixo da nota correspondente ao mesmo comprimento de coluna de ar tocada numa flauta". Outra particularidade é o salto intervalar que ocorre quando o registro ou porta voz é acionado; instrumentos de tubo cilíndrico aberto geram o $2^{\circ}$ harmônico da série harmônica, também conhecida como oitava, enquanto a clarineta gera o $3^{\circ}$ harmônico ou a duodécima. 
Figura 9 - Série harmônica

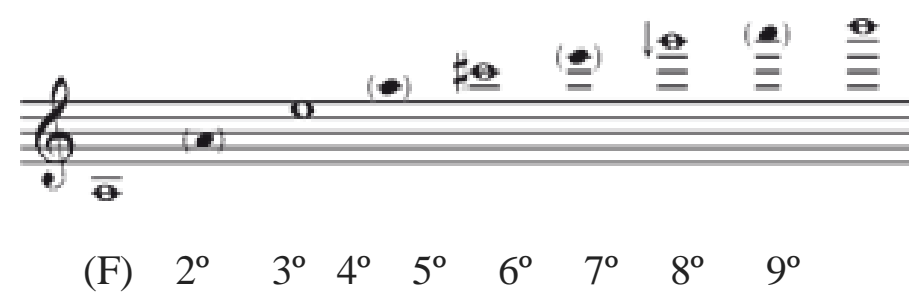

Fonte: RAASAKKA, 2010, p. 74

As notas do $3^{\circ}, 5^{\circ}, 7^{\circ}$ e $9^{\circ}$ harmônicos podem ser produzidas com o mesmo dedilhado, um ajuste na afinação das notas do $5^{\circ}$ e $9^{\circ}$ harmônico se faz necessário.

Figura 10 - Notas destacadas da série harmônica

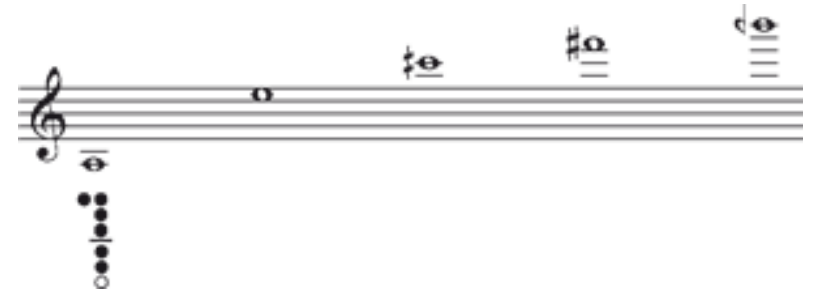

Fonte: RAASAKKA, 2010, p. 76

Aplicamos esta particularidade do instrumento em um estudo de flexibilidade e controle dos harmônicos. Iniciamos o estudo com a nota Mi3 buscando obter as outras parciais geradas pelo instrumento. Isso foi feito através da alteração na embocadura e no trato vocal e com a modulação do fluxo de ar, sempre sem o acionamento do registro ou porta voz. Essa atividade foi feita com todas as notas do chalumeau. Este estudo colaborou com o processo de entendimento tanto dos dedilhados mais adaptáveis a um gesto de dedilhado mais confortável, como para a aquisição de uma memória muscular da embocadura para realizar as notas agudas. Ressaltamos que as sugestões de dedilhados nos livros citados, se referem às vezes a um modelo de instrumento e boquilha em especidico, e que uma adequação das posições se faz necessário.

Durante o processo de aprendizado desses trechos, notamos dois aspectos de desconforto:

a) Com a necessidade de uma maior pressão na palheta, aplicada pelo lábio inferior, notamos um incômodo em estudos de longa duração, observamos que alguns ferimentos ocorreram por conta da fricção entre o dente e o lábio inferior. 
b) Outro aspecto que não colaborou com o estudo de longa duração, foi a fadiga auditiva $^{11}$. Segundo Lorenzzi (2016), "uma exposição do ouvido a um ruído muito intenso, causa uma elevação dos limiares auditivos devido à fadiga das fibras nervosas. Por isso um estudo concentrado e de alto rendimento se mostrou essencial nesse processo".

Segundo Ferron, (1994 p. 8) o registro denominado agudo da clarineta se inicia em seu $5^{\circ}$ harmônico ou na nota Dó\#6. Não encontramos necessidade de anexar as posições de todas as notas da região aguda e estabelecemos como referência notas acima do Mi6.

Com as digitações pré estabelecidas, o método (CIE) foi acrescentado ao estudo e observamos que alterações na divisão musical original, fermatas em diferentes notas, estudo na forma retrógrada e aplicação de diferentes articulações, se mostraram eficientes na assimilação e memorização dos trechos.

Trechos musicais e as posições sugeridas:

Figura 11 - Compassos 60 e 61

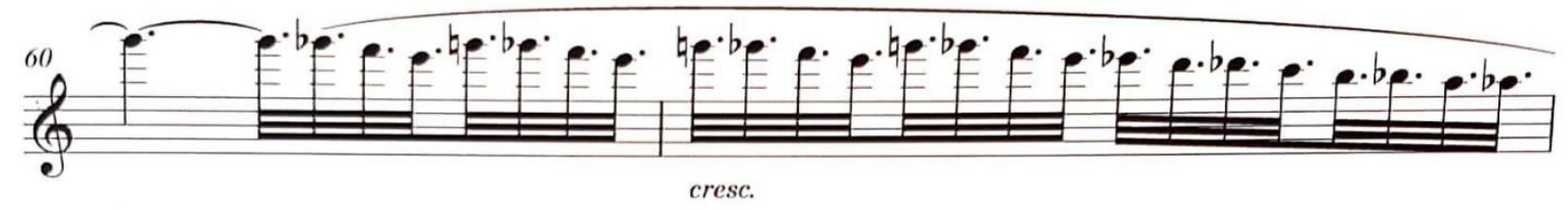

Fonte: LINDBERG, 2013, p. 3

Quadro 1 - Posições sugeridas

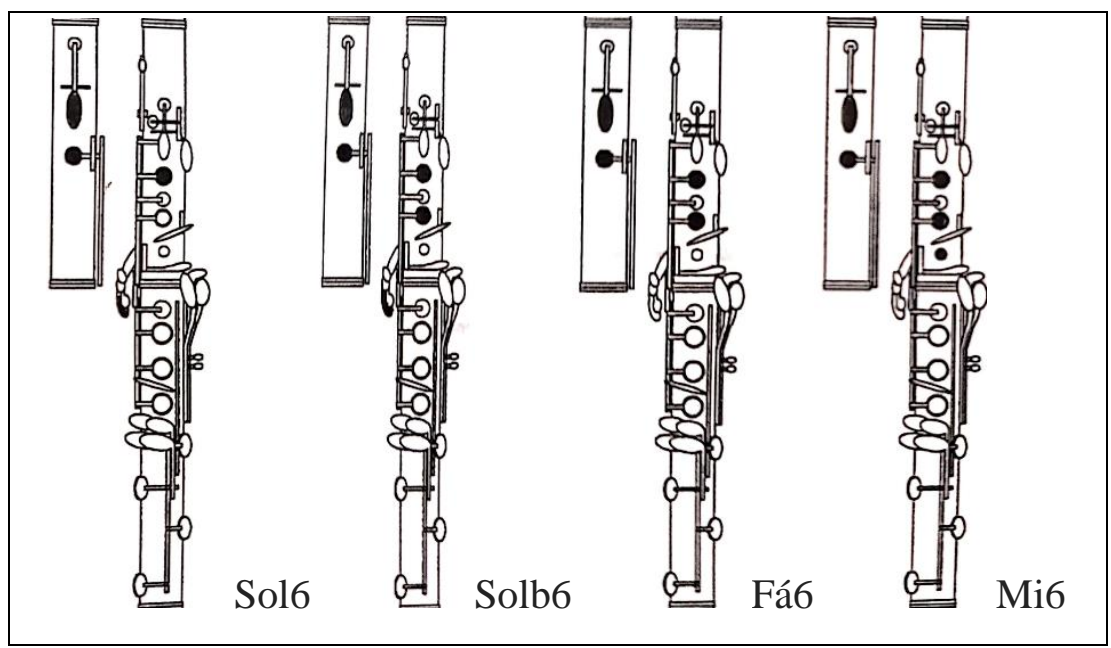

Fonte: Adaptado de HELENO, 2005.

${ }^{11}$ LORENZI, Antoine; TRIGUEIROS-CUNHA, Nuno. Psicoacústica. Voyage au centre de l'audition, 2018. Disponível em: http://www.cochlea.eu/po/som/psicoacustica. Acesso em: 9 fev. 2018. 
Figura 12 - Compassos 76-81
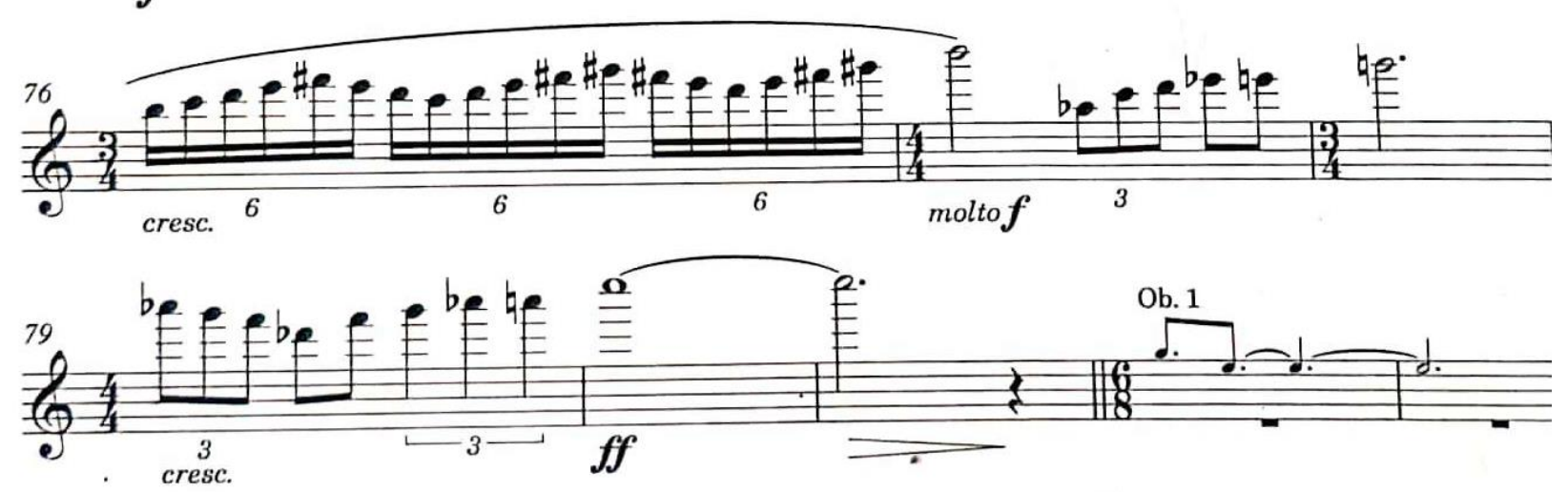

Fonte: LINDBERG, 2013, p. 3

Quadro 2 - Posições sugeridas

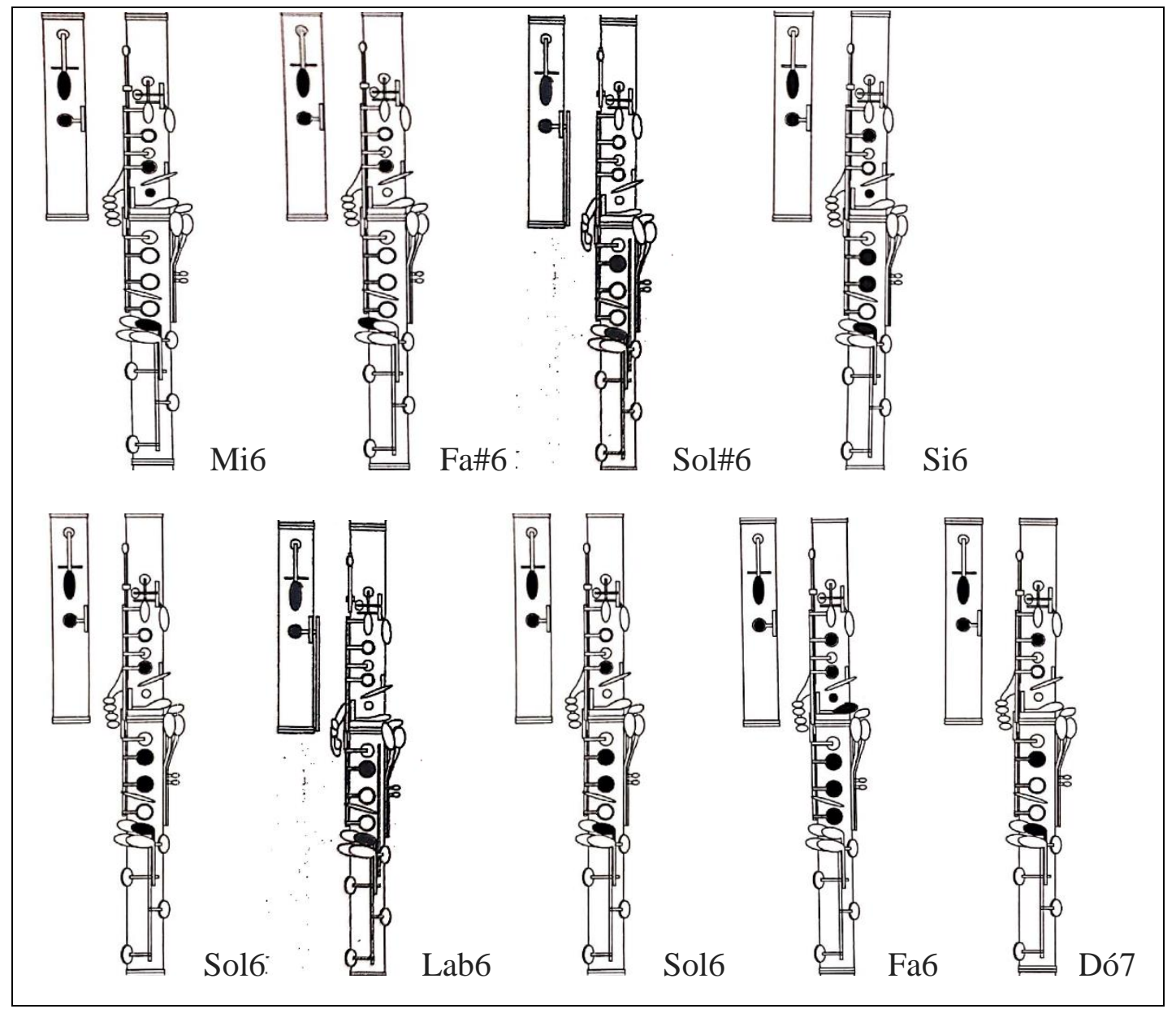

Fonte: Adaptado de HELENO, 2005. 
Figura 13 - Compassos 125-127

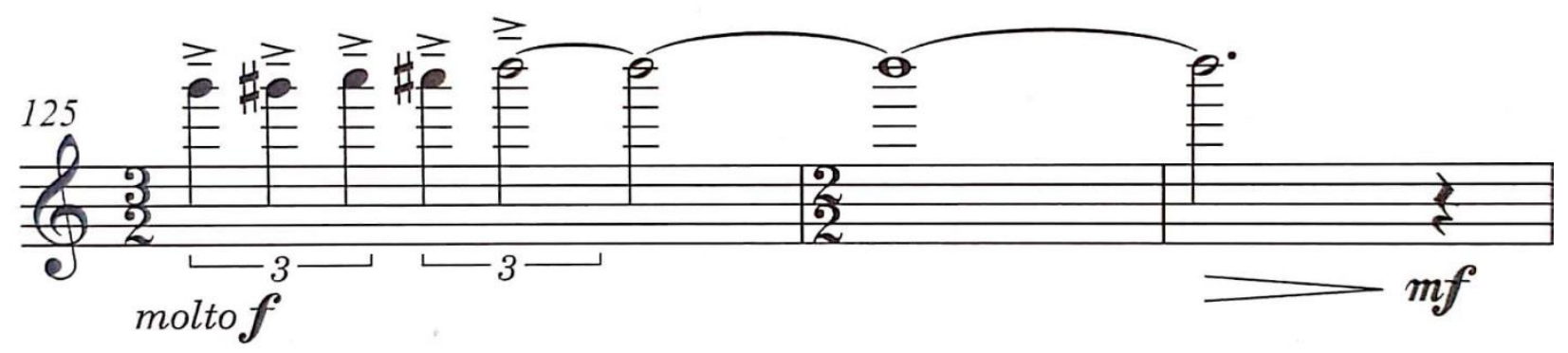

Fonte: LINDBERG, 2013, p. 5

Quadro 3 - Posições sugeridas

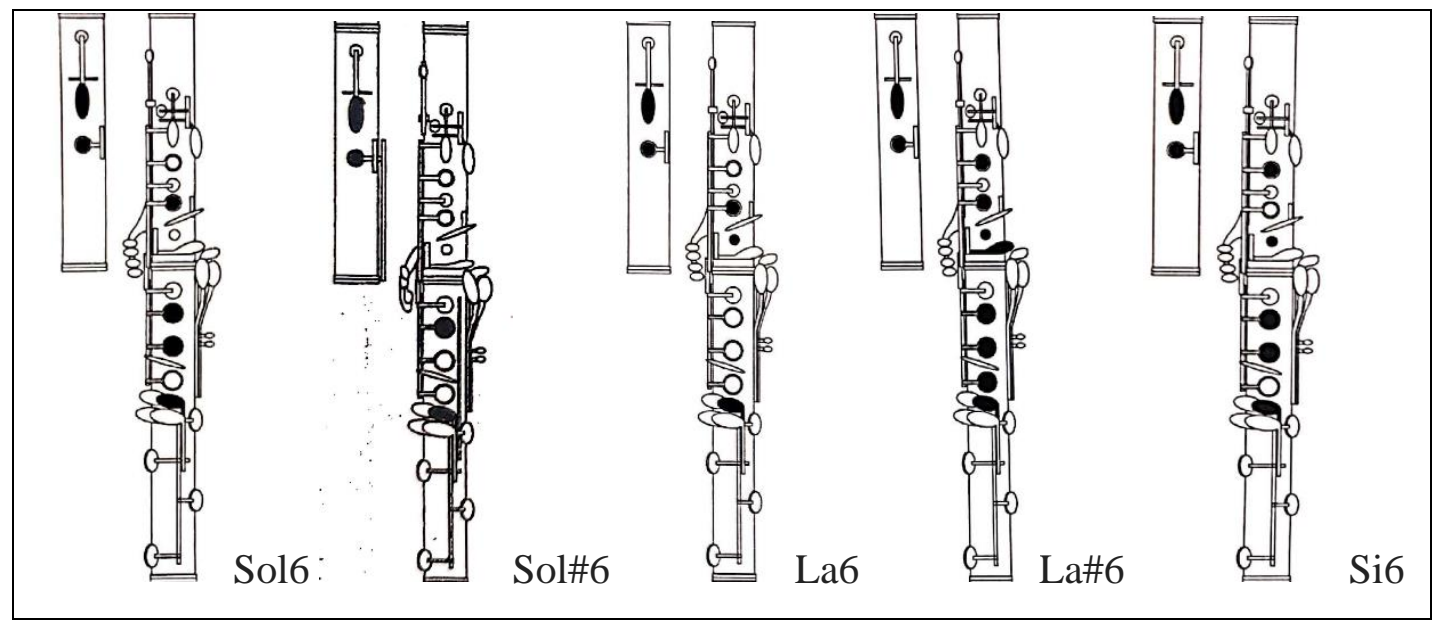

Fonte: Adaptado de HELENO, 2005.

Figura 14 - Compassos 211-212

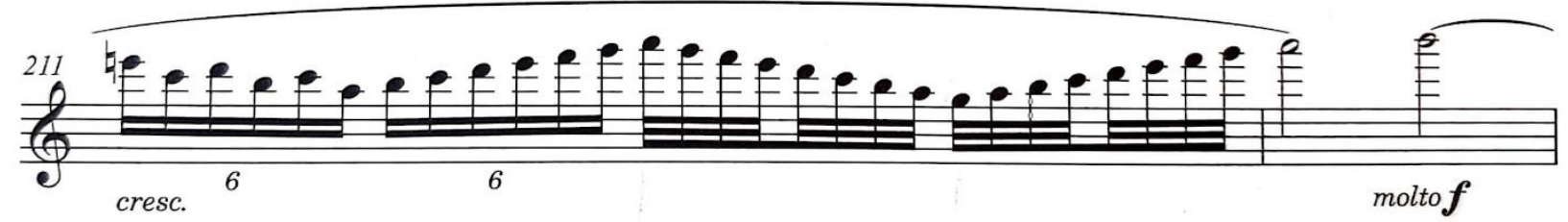

Fonte: LINDBERG, 2013, p. 9a 
Quadro 4 - Posições sugeridas

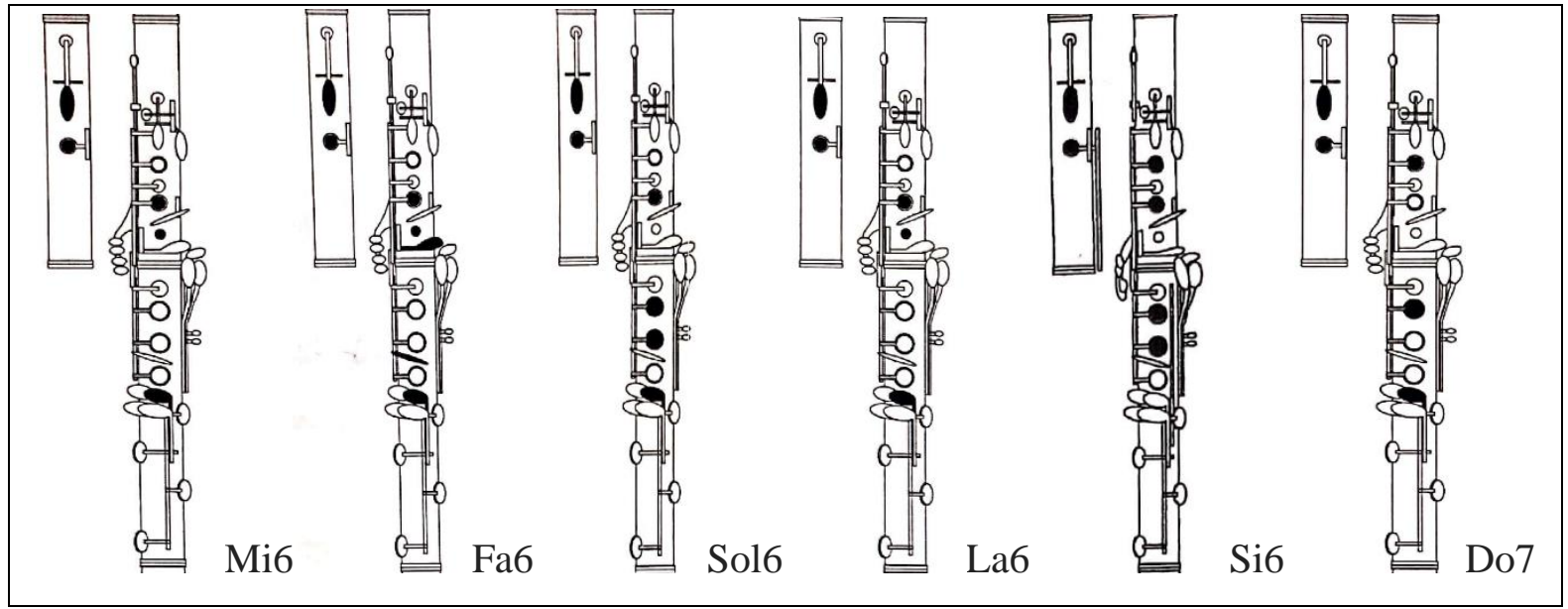

Fonte: Adaptado de HELENO, 2005.

Figura 15 - Compassos 272-279
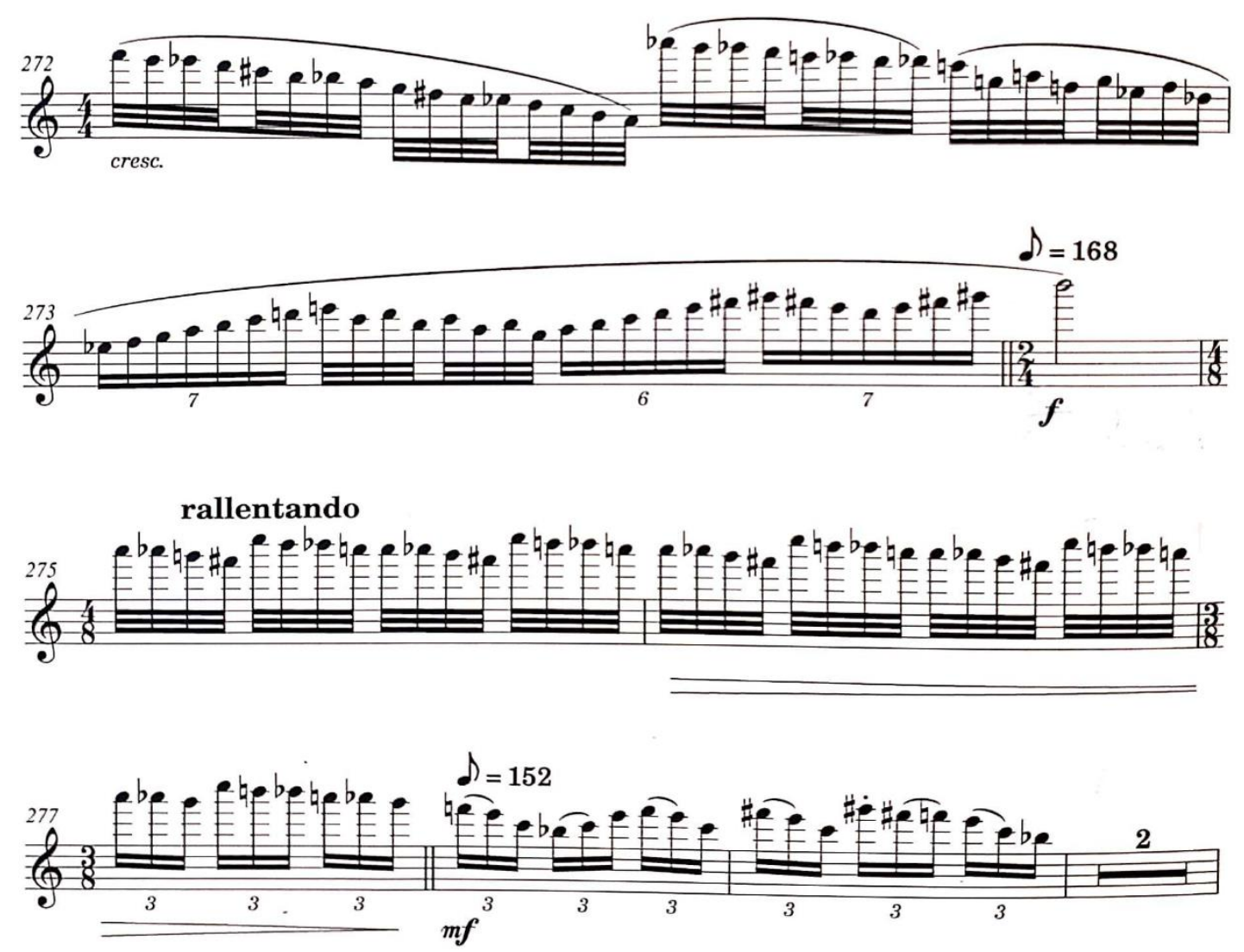

Fonte:

LINDBERG, 2013, p. 12 
Quadro 5 - Posições sugeridas

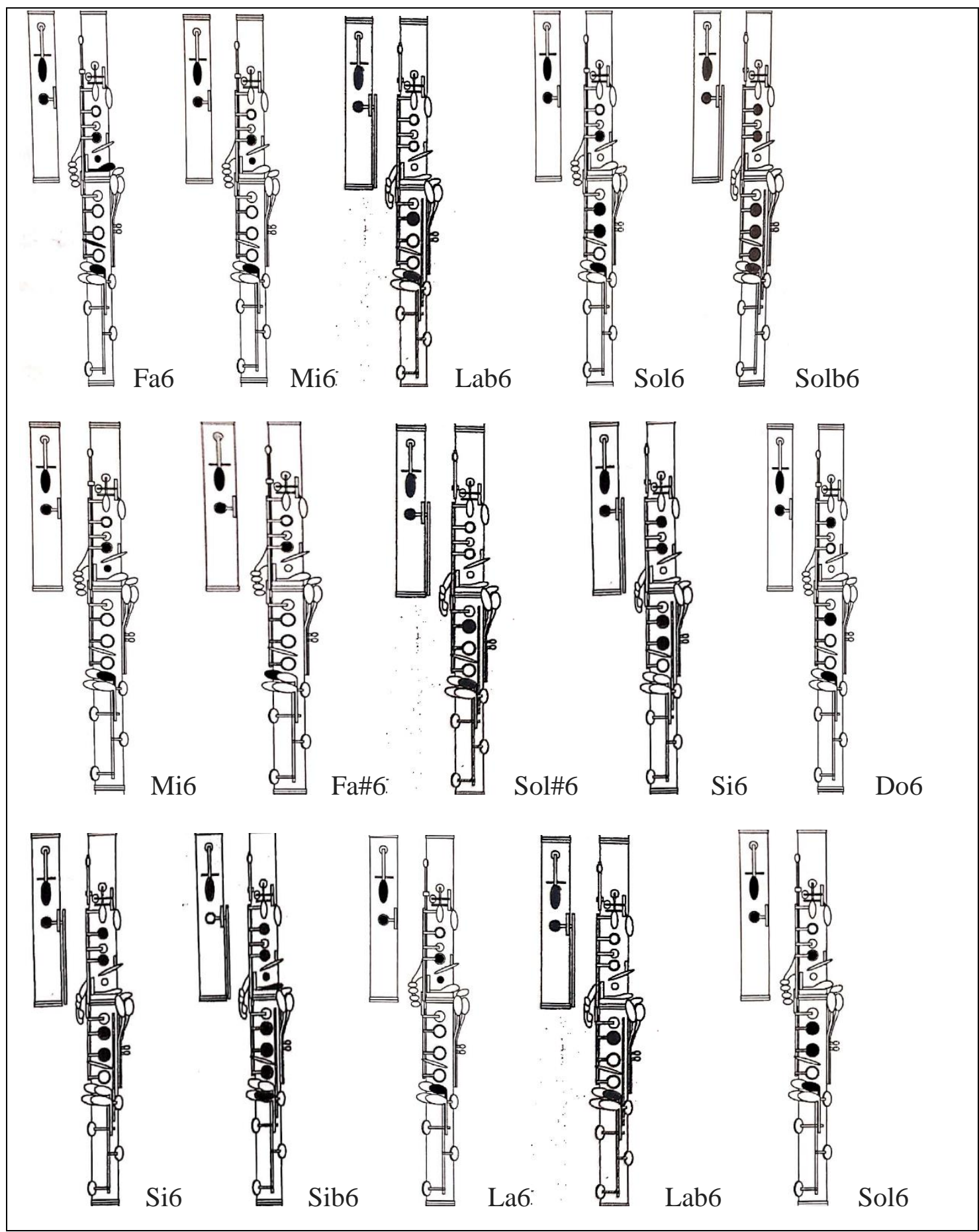

Fonte: Adaptado de HELENO, 2005. 
Quadro 5 - Posições sugeridas - continuação

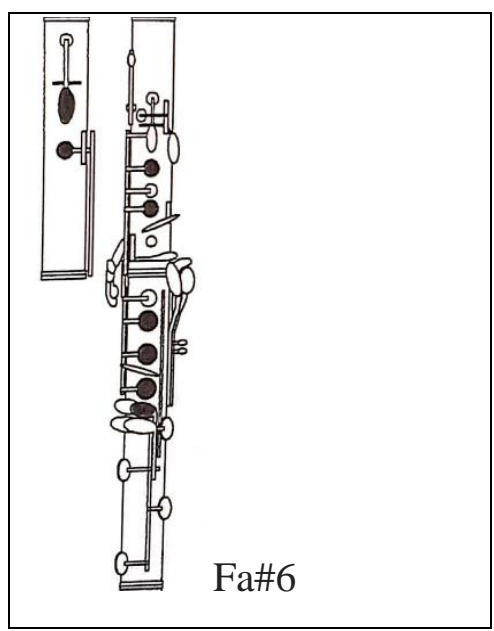

Fonte: Adaptado de HELENO, 2005.

Figura 16 - Compassos 350-353

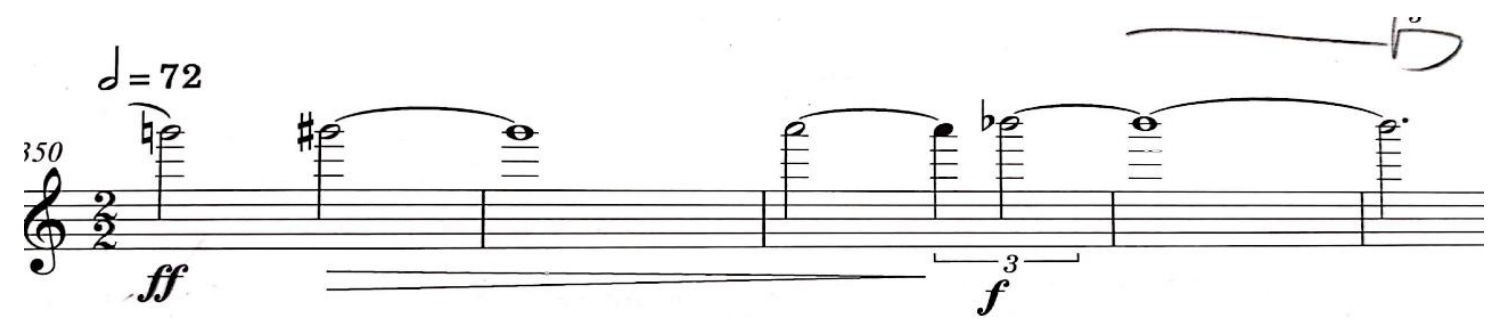

Fonte: LINDBERG, 2013, p. 15

Quadro 6 - Posições sugeridas

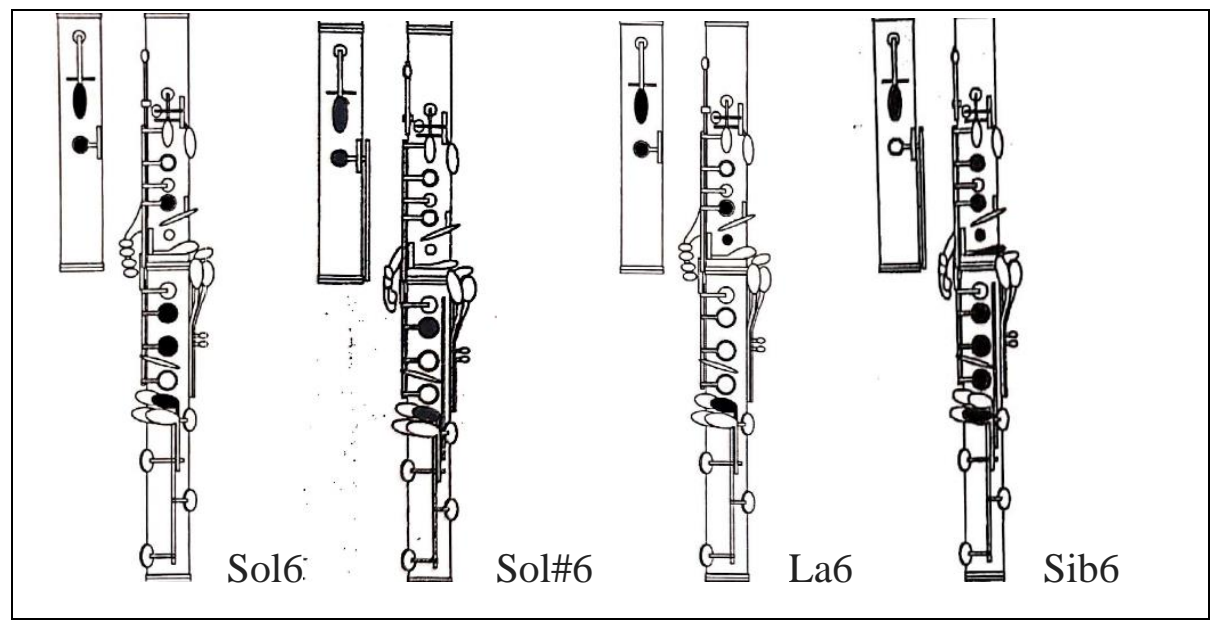

Fonte: Adaptado de HELENO, 2005. 
Quadro 7 - Compasso 389

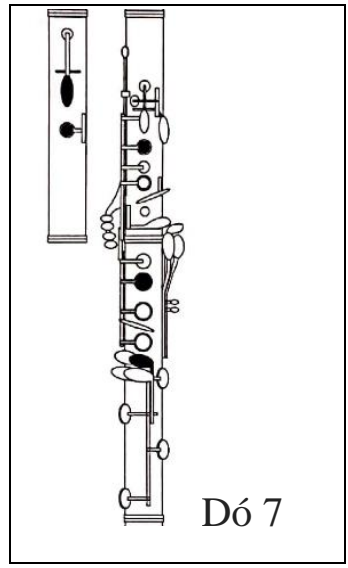

Fonte: Adaptado de HELENO, 2005.

Quadro 8 - Compasso 404

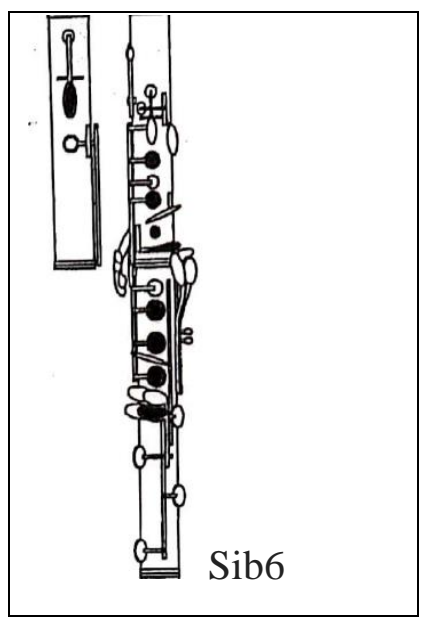

Fonte: Adaptado de HELENO, 2005.

Figura 17 - Compassos 411-416

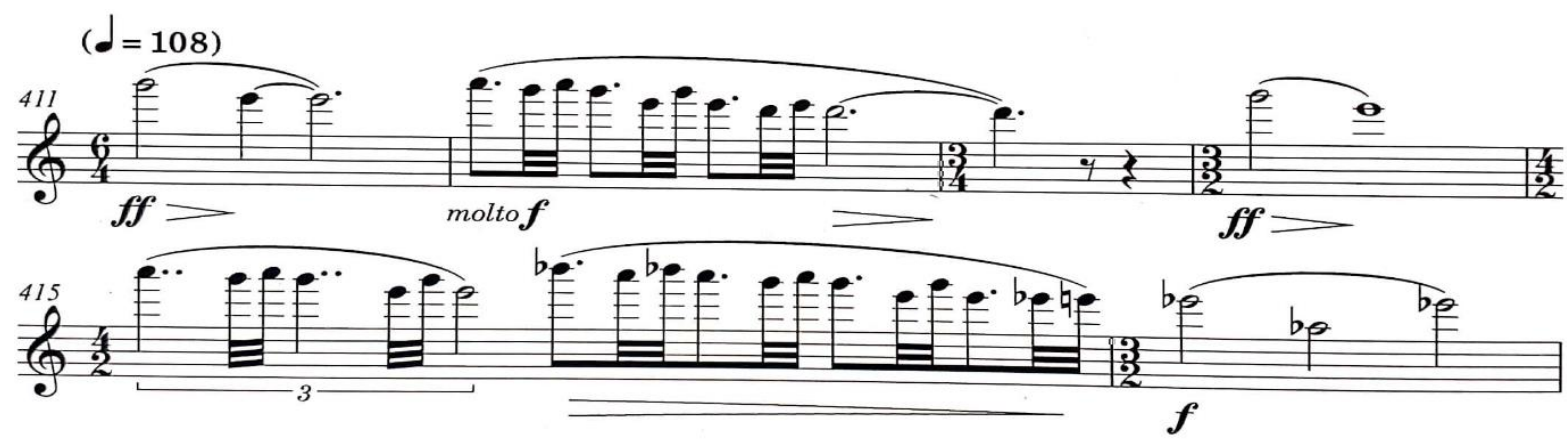

Fonte: LINDBERG, 2013, p. 18 
Quadro 9 - Posições sugeridas

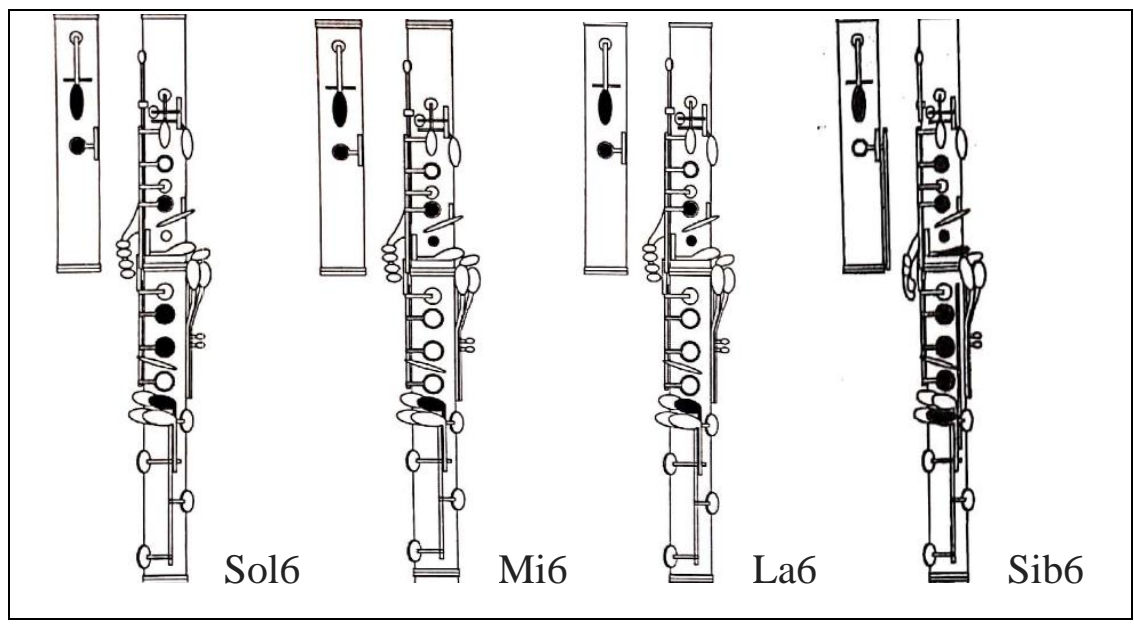

Fonte: Adaptado de HELENO, 2005.

Figura 18 - Compassos 531-532
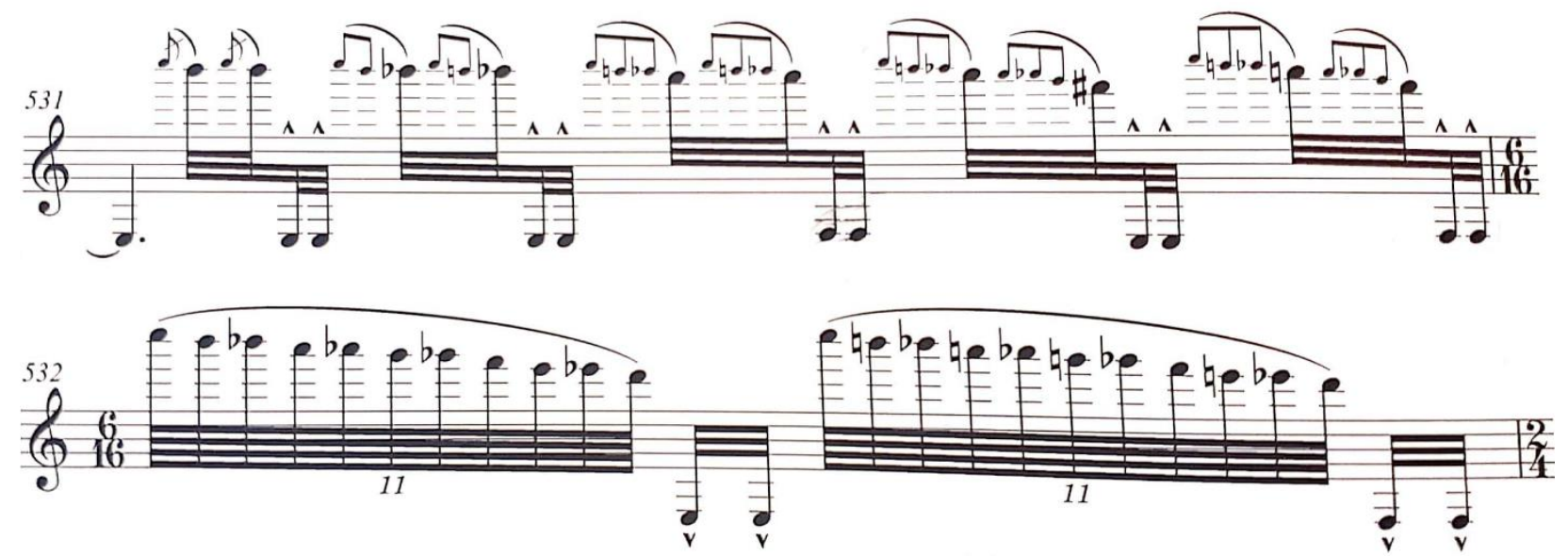

Fonte: LINDBERG, 2013, p. 22 
Quadro 10 - Posições sugeridas

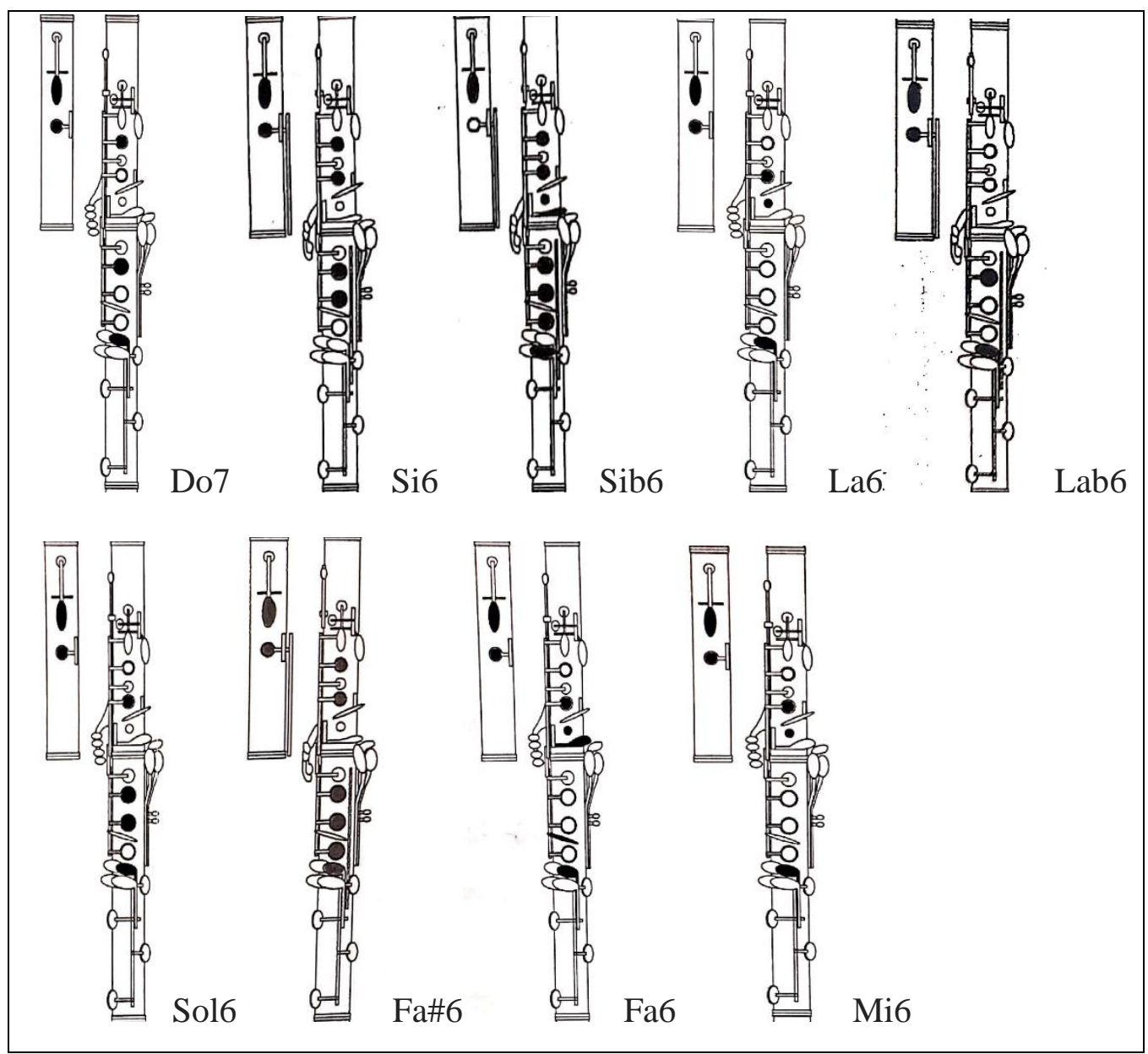

Fonte: Adaptado de HELENO, 2005.

Quadro 11 - Compasso 534

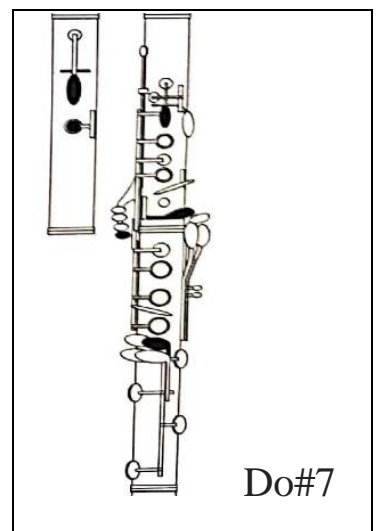

Fonte: Adaptado de HELENO, 2005. 
Figura 19 - Compasso 549

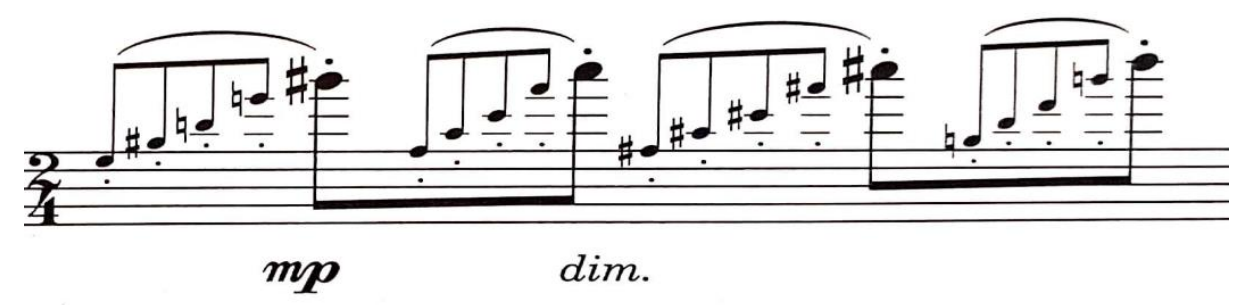

Fonte: LINDBERG, 2013, p. 23a

Quadro 12 - Posições sugeridas

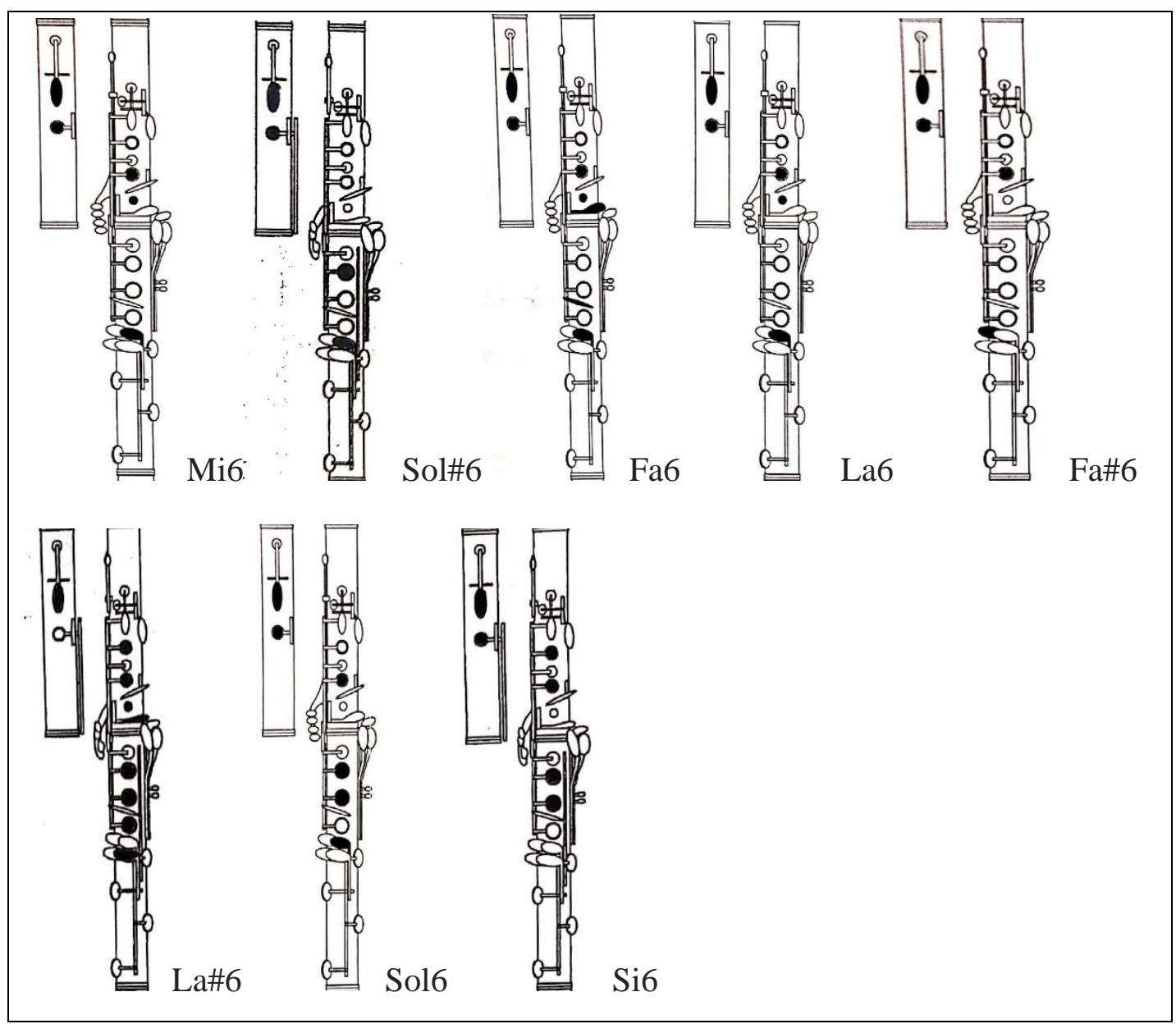

Fonte: Adaptado de HELENO, 2005. 
Figura 20 - Compasso 594

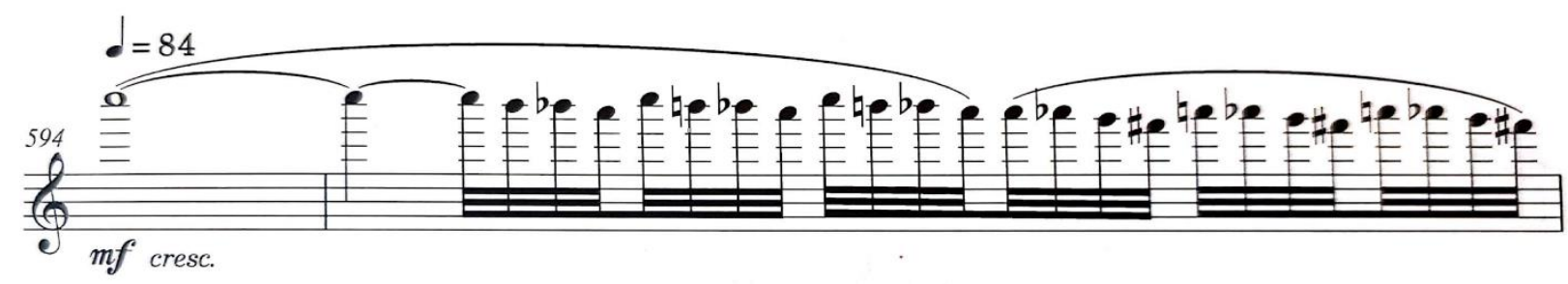

Fonte: LINDBERG, 2013, p. 25

Quadro 13 - Posições sugeridas

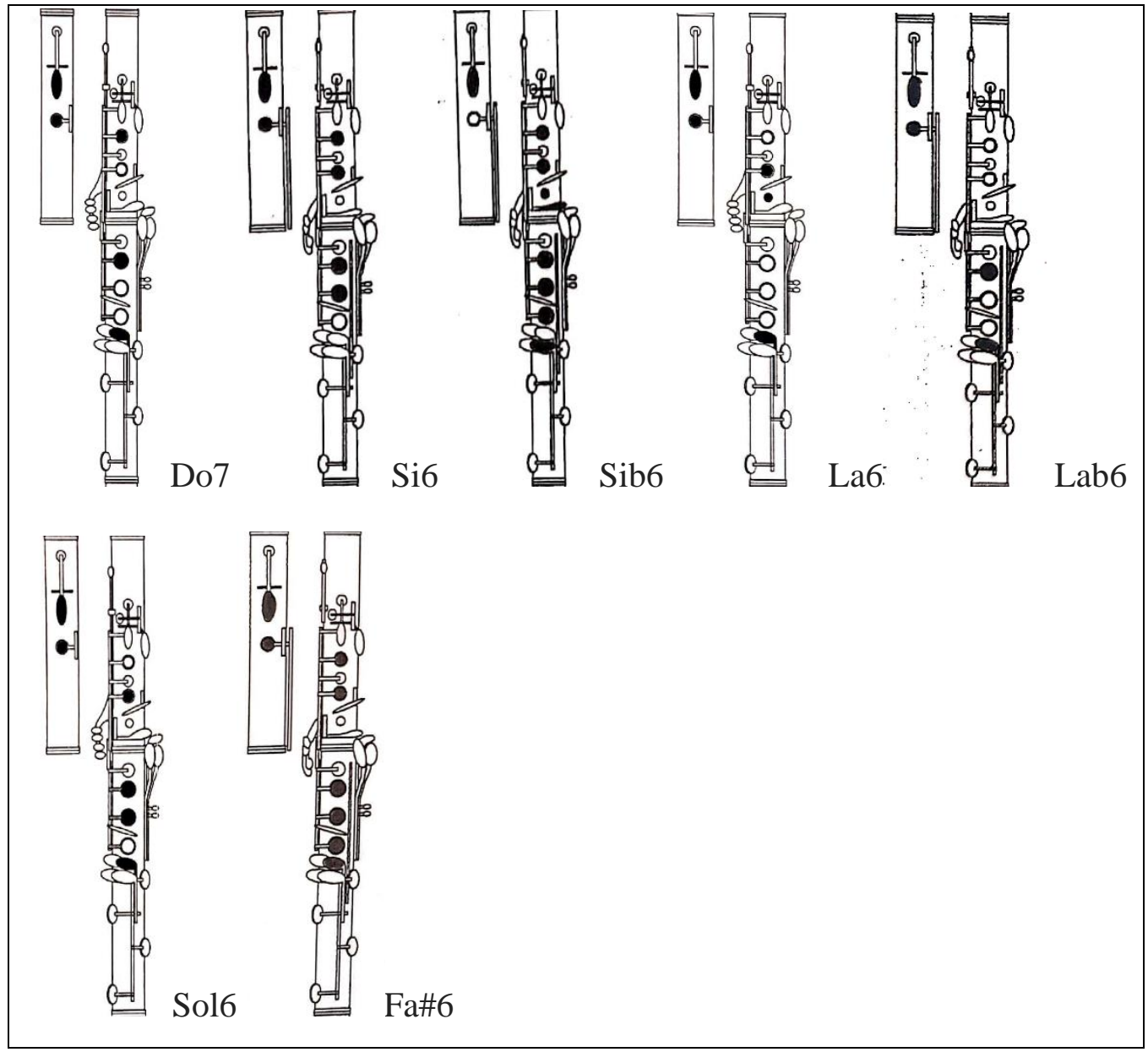

Fonte: Adaptado de HELENO, 2005. 
Figura 21 - Compassos 654-657
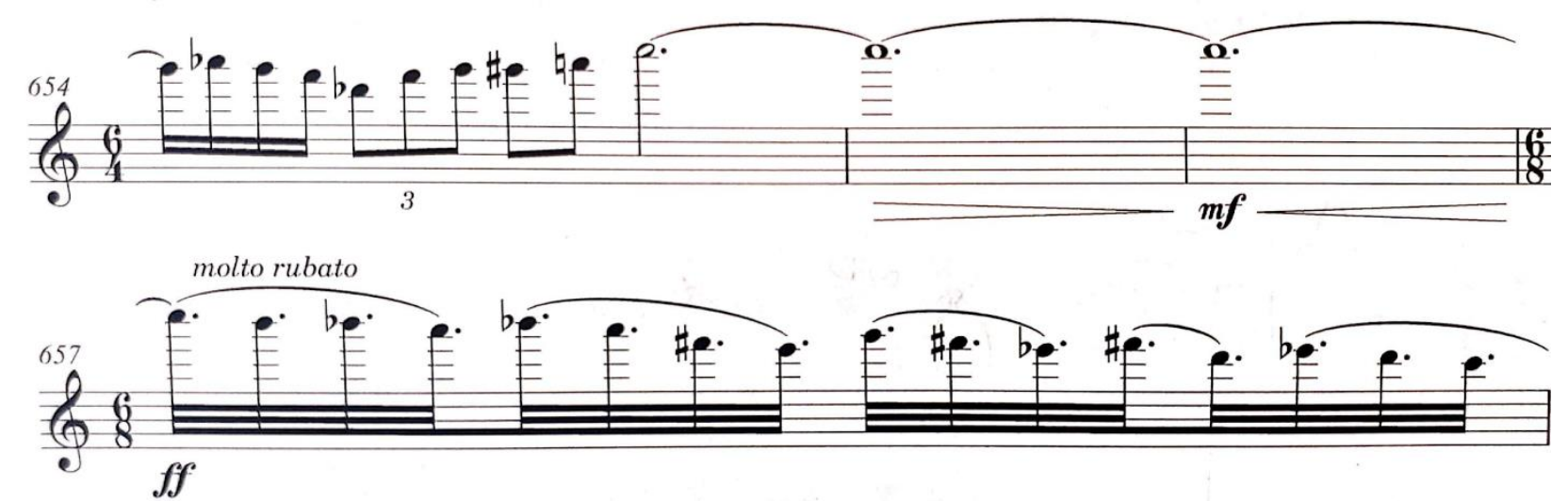

Fonte: LINDBERG, 2013, p. 28

Quadro 14 - Posições sugeridas

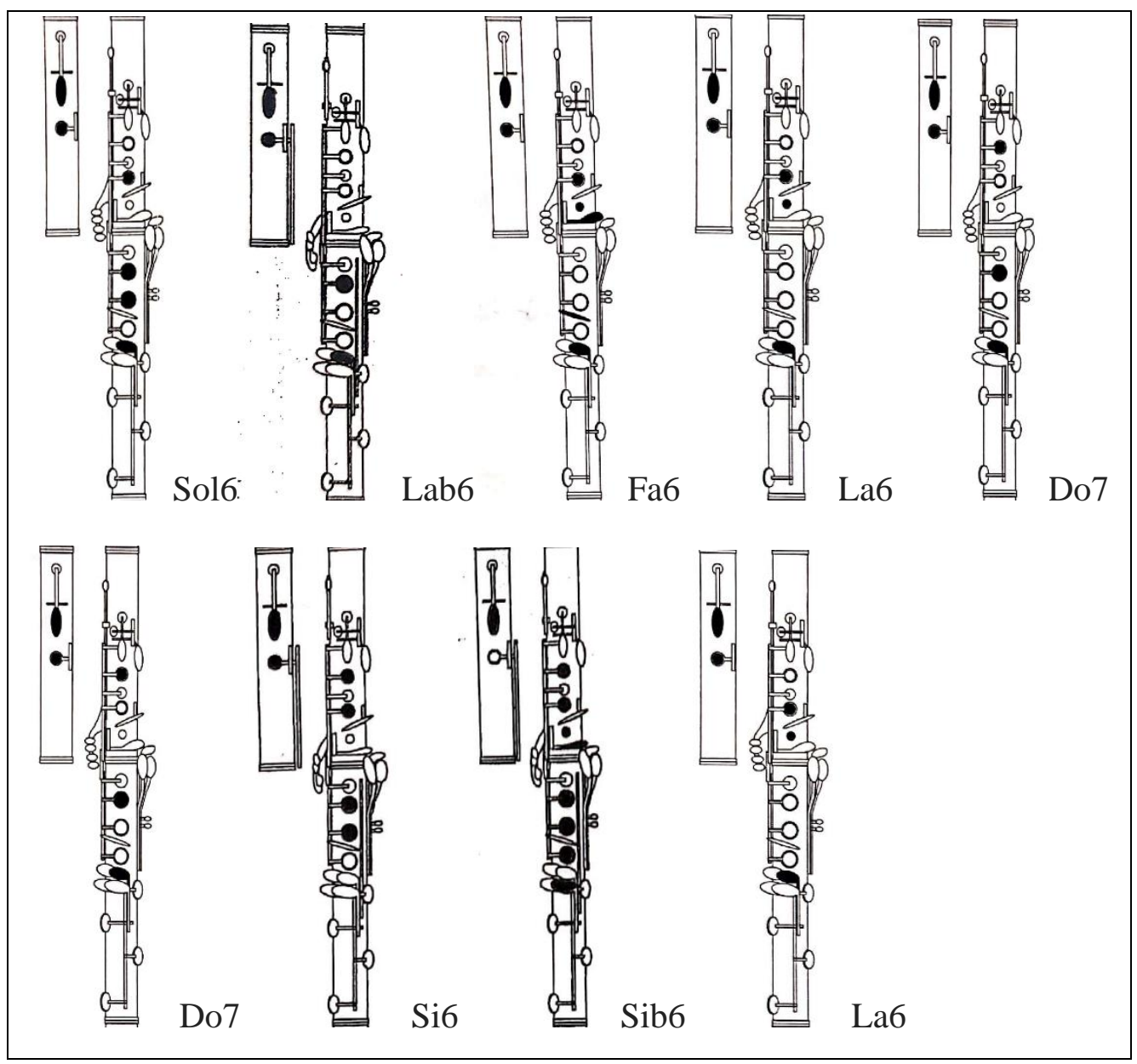

Fonte: Adaptado de HELENO, 2005. 
Quadro 14 - Posições sugeridas

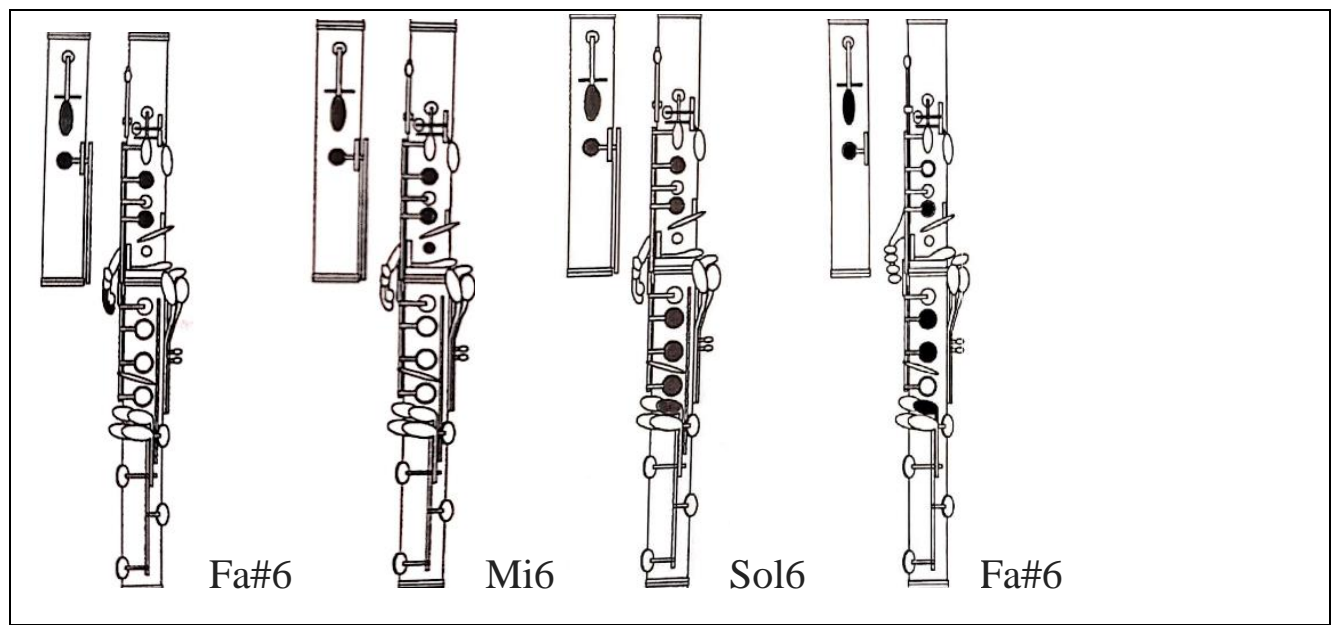

Fonte: Adaptado de HELENO, 2005.

Figura 22 - Compasso 662

\section{rallentando}

molto rubato

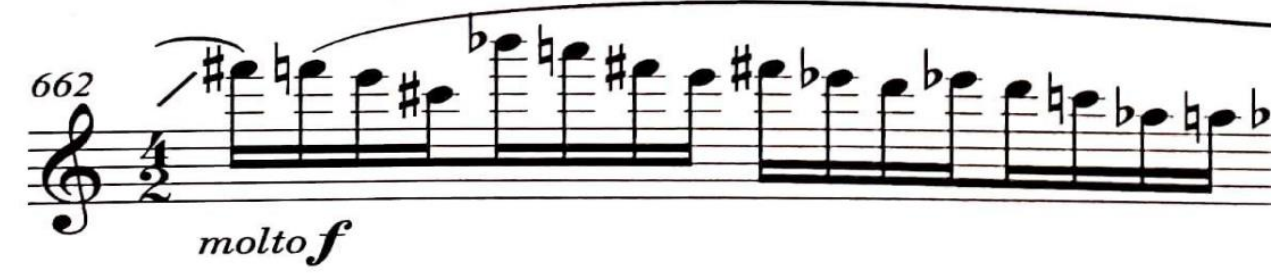

Fonte: LINDBERG, 2013, p. 28

Quadro 15 - Posições sugeridas

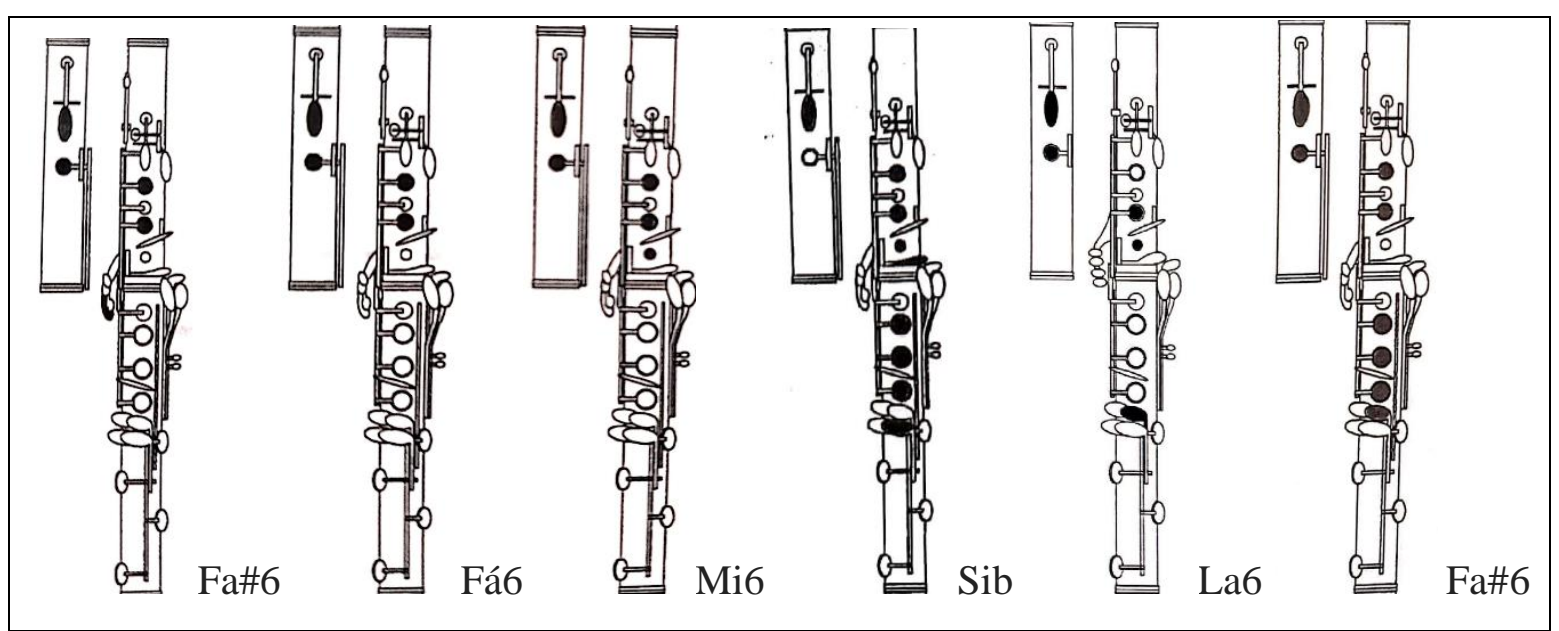

Fonte: Adaptado de HELENO, 2005. 


\subsubsection{Trêmulos}

Uma notação recorrente no concerto de Lindberg, é a grafia de duas notas, uma em cima da outra e com um trêmolo anotado acima. Isso significa tremular entre as duas notas escritas, sempre começando com a nota inferior.

Figura 23 - Compasso 180

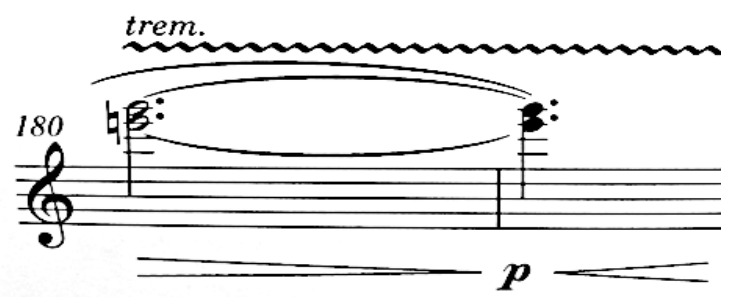

Fonte: LINDBERG, 2013, p. 8

A digitação necessária para realizar os trêmulos nos mostra um dos momentos da colaboração do performer com a escrita do concerto. A notação na Figura 24 refere-se às chaves 11 bis e 10bis, o clarinetista toca a nota inferior escrita e aciona as chaves indicadas, realizando assim o efeito desejado.

Figura 24 - Compassos 255-257

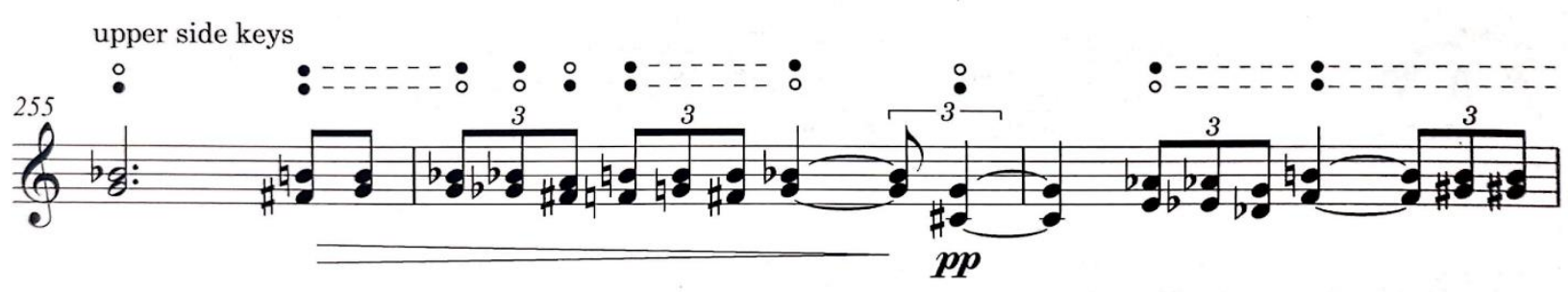

Fonte: LINDBERG, 2013, p.11

As posições de dedilhados sugeridas na partitura foram elaboradas pelo intérprete e servem como um guia. Outra peculiaridade são os trêmulos em regiões específicas do instrumento, ora na chalumeau ora no clarino, o que contribuiu para um discurso mais fluente. Ressaltasse que sem o conhecimento específico das regiões do instrumento essa possibilidade não seria explorada.

O estudo deste trecho foi separado em duas partes: 
a) estudo da linha melódica inferior e superior separadas, para um melhor entendimento da condução da frase e pontos de apoio. Além disso este estudo colaborou para determinar quais notas seriam importantes e quais poderiam ficar em segundo plano no discurso. Notamos que a melodia traçada durante os trêmulos é o resultado da soma das duas notas e o objetivo na execução é criar uma sensação de polifonia durante este trecho;

b) estudo sem metrica definida, com paradas em cada trêmulo, para compreender qual seria a melhor maneira de direcionar o ar e a abertura do trato vocal. Esta atividade contribuiu para um entendimento de como trabalhar os intervalos de maneira orgânica e manusear uma textura sonora mais homogênea. A utilização de vogais durante o estudo cooperou para encontrar uma abertura do trato vocal que fosse aceitável na produção do som. A vogal [o] foi utilizada nos trêmulos com saltos superiores a quartas justas e na região do chalumeau do instrumento, e as vogais [é] e [i] foram utilizadas na região do clarino e em trêmulos com intervalo inferiores a quartas justas.

Para os trêmulos na região aguda do instrumento foi utilizado os mesmos guias de posições adotados no trabalho da dificuldade anterior e utilizamos a vogal [i] na produção do som.

\subsubsection{Arpejos}

Os excertos musicais enquadrados nesta dificuldade, são formados por arpejos que utilizam toda a extensão do instrumento, sendo que o que torna esses trechos complexos é a velocidade exigida pelo compositor. A primeira abordagem utilizada foi tocar todos os trechos em uma velocidade muito lenta e sempre em fortíssimo, com o objetivo de desenvolver ao mesmo tempo respirações profundas, apoio da coluna de ar, pressão de ar, abertura do trato vocal e projeção do som. Este trabalho, lento, permitiu observar o relaxamento dos músculos envolvidos na performance e ter consciência do movimento do corpo.

A segunda abordagem adotada foi a de fragmentação dos frases musicais e aplicação de figuras pontuadas, também reduzindo os arpejos em figuras menores, primeiro com 3 notas, depois 4 e acrescentando até chegar a um conjunto de 12 . O trecho onde demandou uma maior atenção foi entre os compassos 197 e o compasso 203, onde é intercalado arpejos com notas repetidas articuladas, sendo que a ausência de um local que permita respirar acrescenta uma dificuldade maior. As abordagens descritas acima foram utilizadas nos trechos: 
Figura 25 - Compassos 197-203
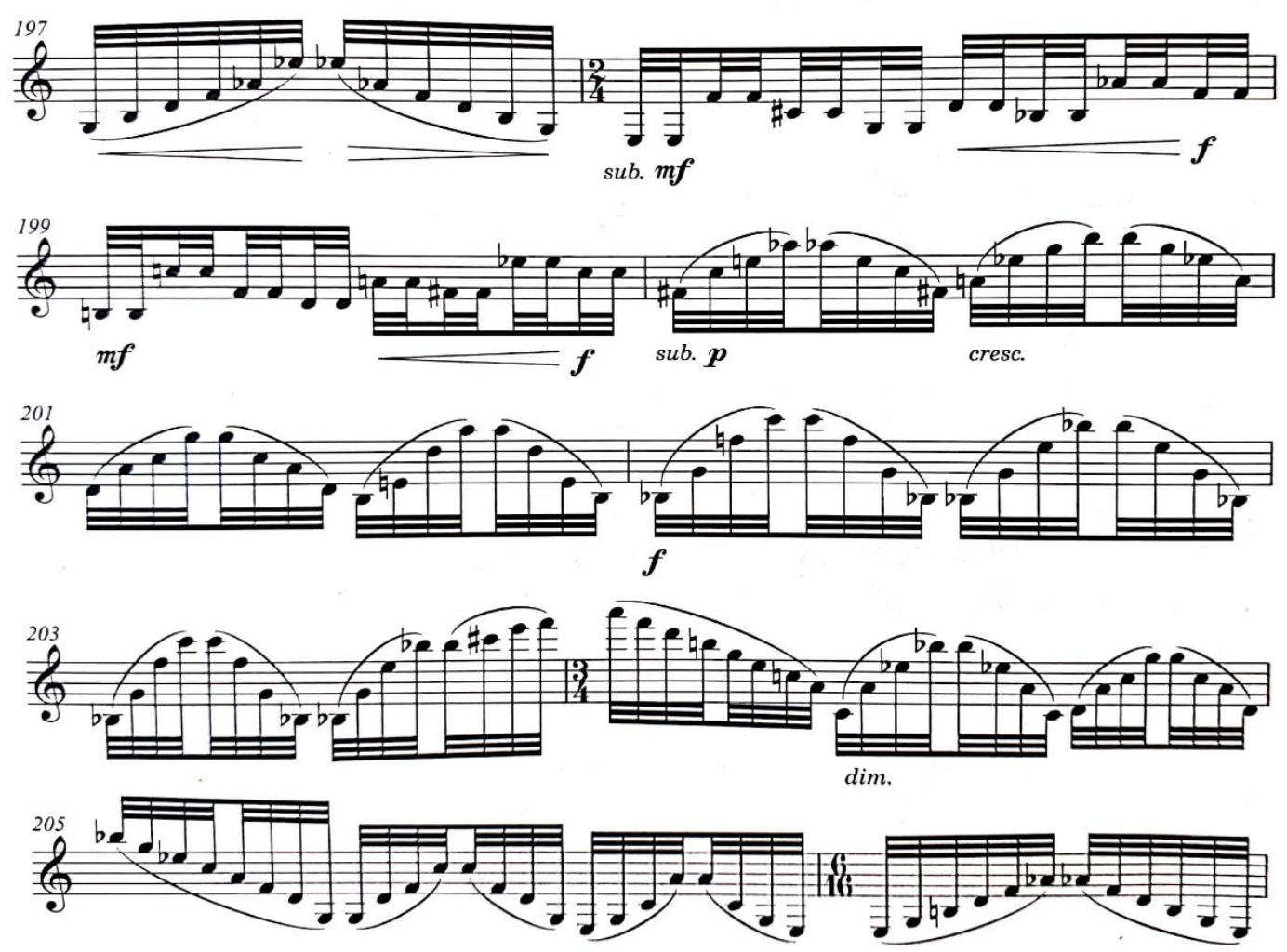

Fonte: LINDBERG, 2013, p. 9

Figura 26 - Compassos 527-528
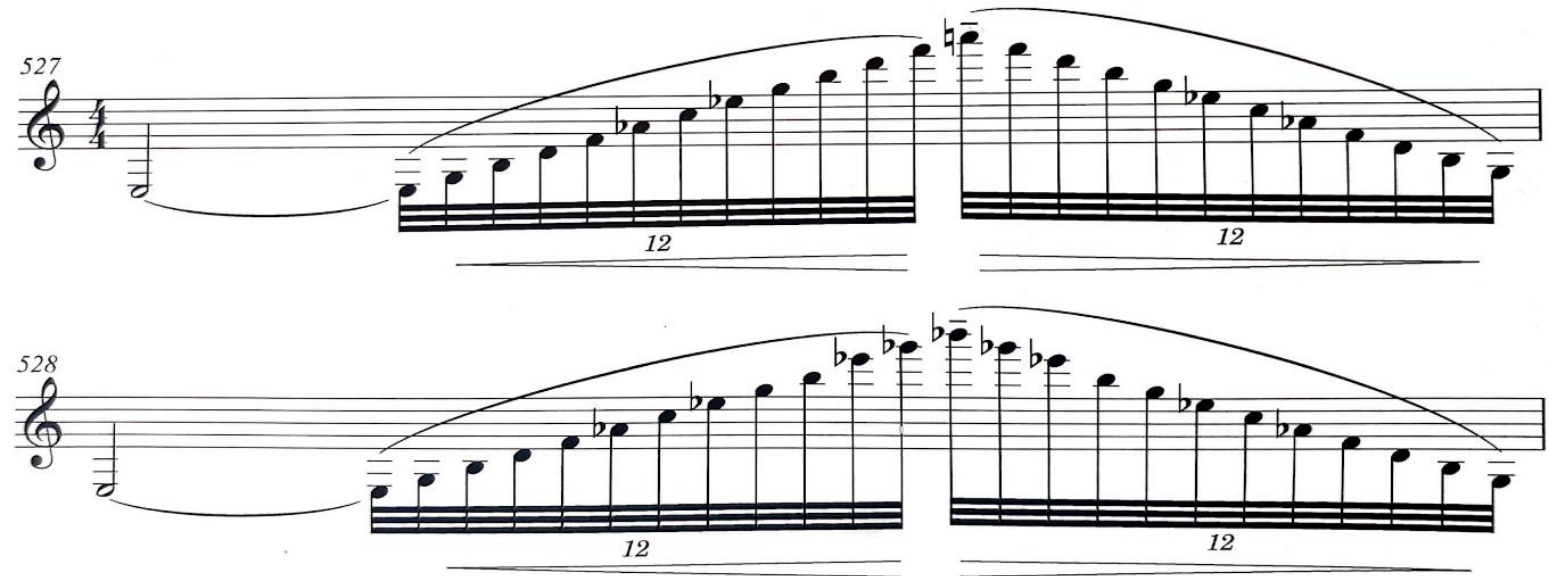

Fonte: LINDBERG, 2013, p. 22 
Figura 27 - Compassos 542-545
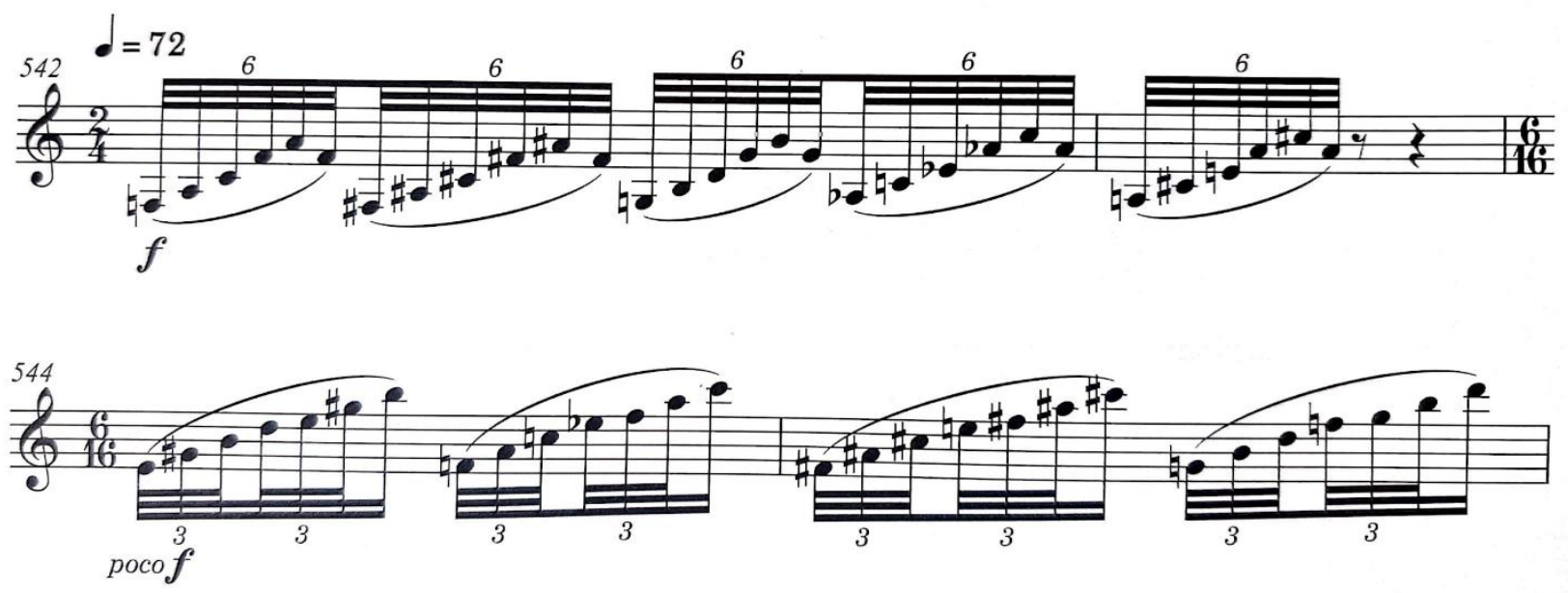

Fonte: LINDBERG, 2013, p. 23a

\subsubsection{Articulação}

Alguns trabalhos sugerem o staccato duplo na execução dos trechos destacados e encontramos em Raasakki (2009, p.106) e Morell (2014, p.84), uma referência da utilização desta técnica aplicada ao concerto. Compreendemos que esta sugestão, se deve a grande velocidade de língua requerida nos trechos com staccato. Observamos em gravações realizadas pelo intérprete pesquisado, tanto no concerto para clarineta como em outras obras, uma facilidade em realizar o staccato duplo, e constatamos que essa habilidade foi explorada por Lindberg em diferentes trechos da obra. Não encontramos nenhuma referência no texto do concerto, que imponha ao intérprete a utilização do stacatto duplo. Destacamos dois trechos musicais, que exigiam uma articulação destacada e rápida, material este que é repetido ao longo da obra:

Figura 28 - Compasso 236

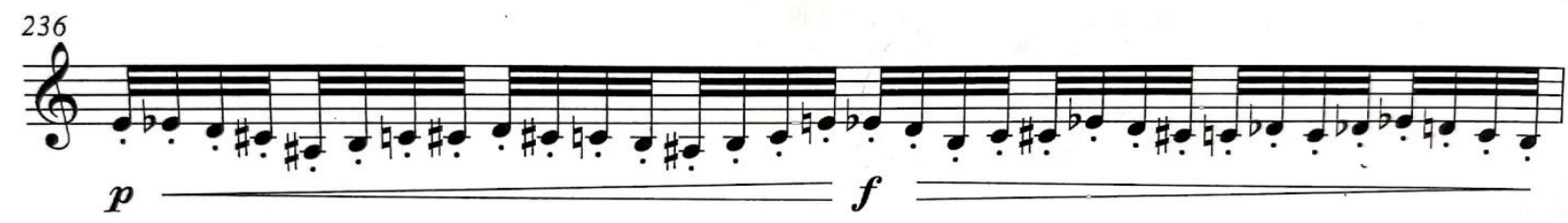

Fonte: LINDBERG, 2013, p. 10 
Figura 29 - Compassos 472-473

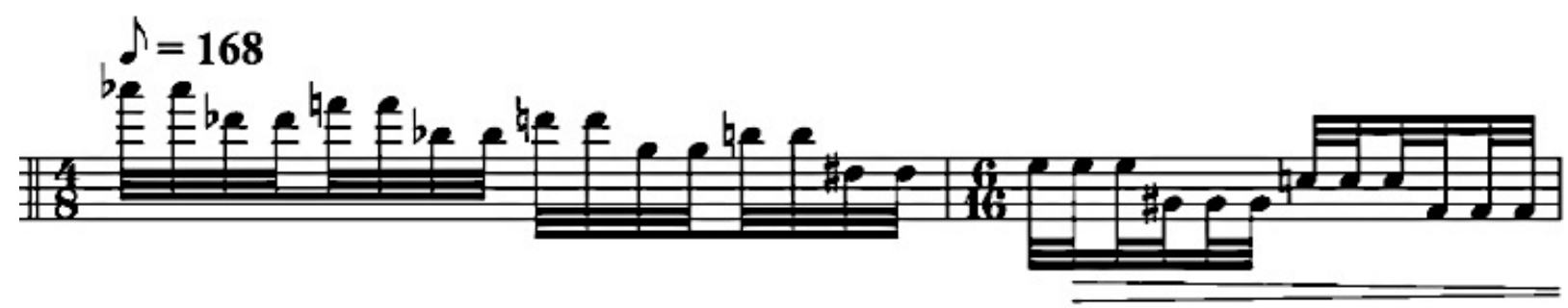

Fonte: LINDBERG, 2013, p. 19a

Neste material destacado, temos dois exemplos de articulação. O primeiro, no compasso 236, possui o sinal de staccato e apresenta um contorno melódico com alturas aproximadas na mesma região do instrumento. No processo de estudo deste trecho, foi explorado a utilização de diversas articulações, mesclando ligaduras com staccatos, tenutos e marcatos; mudanças nas figuras rítmicas, utilização de figuras pontuadas e também a ausênsia de uma métrica definida permitindo enfatizar diferentes notas como ponto de apoio. Durante o desenvolvimento do trabalho, notamos que não seria necessário utilizar o staccato duplo e utilizamos todas as estratégias de aprendizado, aplicando ao staccato simples. Uma observação pertinente para se pontuar no processo de estudo deste trecho, foi a necessidade de desenvolver a habilidade de articular com a língua em contato direto com a palheta. A técnica utilizada normalmente por este pesquisador consiste em colocar o lábio inferior como ponto de ligação entre a língua e a palheta, este procedimento se deve a não adequação a técnica apontada como correta pelos autores consultados.

$\mathrm{Na}$ pesquisa realizada sobre o desenvolvimento das formas de articulação no instrumento, não encontramos referências sobre a utilização do lábio como ponte de contato. No entrando encontramos em Lawson (2000) referências de articulações produzidas com a garganta e com o movimento do tórax para separar as notas com o ar, além de mencionar as primeiras escolas dos clarinetistas como Vanderhagen (1753-1822), Lefèvre (1763-1829) e Backofen (1768 - 1830), como referências no processo de consolidação da técnica atual de articulação. Os autores, Kroll (1965), Pino (1980), Weston (1982) e Dangain (1991) são unânimes em afirmar que a técnica correta de articulação na clarineta, consiste no contato direto da língua com a palheta; as posições exatas de que lugar da língua devemos tocar na palheta, ou mesmo em que região da palheta temos de encostar não são claras, mas salientam a 
importância do respeito com a fisiologia de cada indivíduo. Encontramos na utilização da técnica tradicional, uma facilidade de clareza e velocidade na maneira de articular, mas foi necessário realizar uma adequação na embocadura para um melhor aproveitamento dos benefícios desta técnica. Um estudo adicional foi elaborado, baseado nas possibilidades da flexibilidade e adequação da embocadura quando necessário. Este treinamento consistia em mudar de uma embocadura para outra a qualquer momento durante o estudo, convertendo esta variável em uma sugestão de interferência do contexto. A utilização desta maneira de articular só foi utilizada na performance nos compassos 236 e 238.

Na figura 29 destacamos outro exemplo, localizado no compasso 472. Aqui o compositor utilizou notas repetidas e com uma articulação rápida em diferentes regiões do instrumento, variando entre o agrupamento de 2 e 3 notas. As repetições de uma mesma nota articulada é um fator que pode levar a uma fadiga no músculo da língua e para que o fluxo musical não fosse prejudicado, a adoção de um método de stacattos se mostrou necessário para o domínio desta parte e de outras que empregam esta mesma ideia. Entre os métodos consultados, encontramos em Ferdinand Gillet, Exercices sur les gammes, les Intervalles et le Staccato - 1968 - Alphonce Leduc - Paris, sugestões pertinentes para trabalhar esse trecho e adotamos como sugere o autor, uma sutil acentuação na primeira nota de cada conjunto e uma maior velocidade de ar dentro da boquilha. O resultado obtido com o processo de estudo se mostrou satisfatório e estas novas abordagens foram incorporadas ao repertório de estudo do intérprete.

\subsection{TÉCNICAS ESTENDIDAS}

O concerto faz uso de algumas técnicas estendidas no seu discurso, encontramos em uma bibliografia especializada, descrições e sugestões de como realizar estes efeitos, além de agregar o conhecimento empírico do pesquisador no processo de estudo.

\subsubsection{Multifônicos}

As indicações para este efeito aparece em 4 trechos do concerto, mas somente uma possui posição de digitação sugerida. Esta indicação ocorre nos compassos 135, 144 e 422, no compasso 355 é sugerida uma posição de digitação para realizar o multifônico. 
Figura 30 - Multifônico sem posição sugerida

\section{multiphonics}

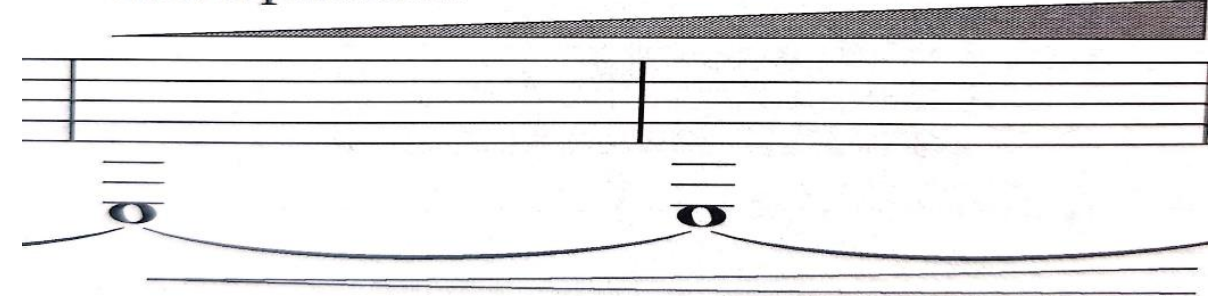

Fonte: LINDBERG, 2013, p. 22

Figura 31 - Multifônico com posição sugerida

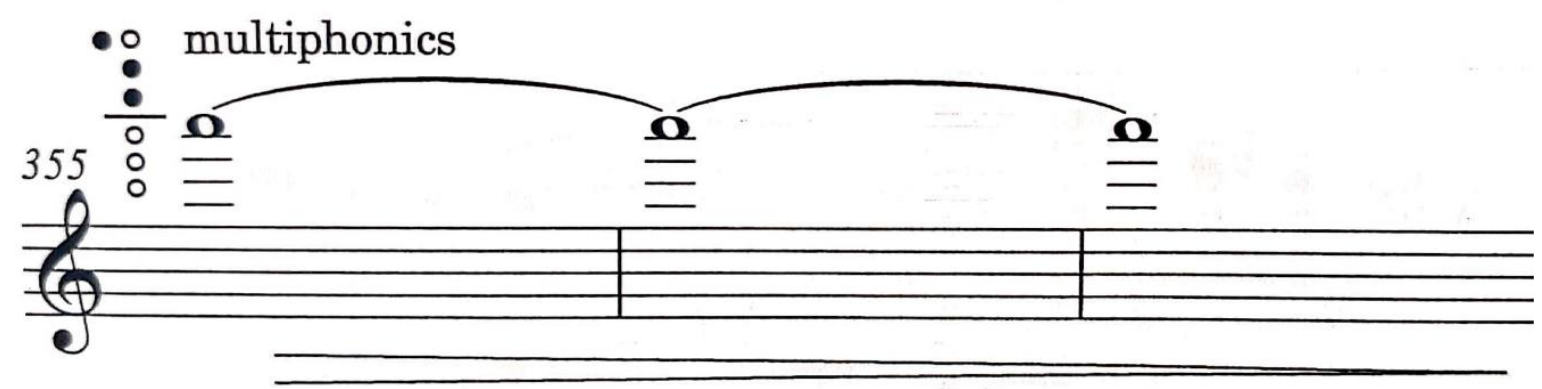

Fonte: LINDBERG, 2013, p. 15

Durante a pesquisa das possibilidades de multifônicos que possuem a nota Mi3 como fundamental, não encontramos na bibliografia especializada digitações possíveis Segundo Raasakka (2009), o termo "broken low tones", que é um efeito descrito da seguinte maneira:

Broken low tones, seria trazer à tona as parciais superiores da nota dedilhada, as notas onde são mais propícias este efeito se encontram na região grave do instrumento, nas notas Mi3, Fá3, Fa\#3 e Sol3. Essas notas geram uma coluna de som espessa e ricamente dissonante sobre as fundamentais. Geralmente são anotados com a letra $\mathrm{M}$ em cima da nota fundamental ou a nota que soa mais alta e a letra M entre eles (Raasakka, 2009, p. 172, tradução nossa).

Consideramos esta descrição como sendo a mais aproximada do efeito sugerido pelo compositor e analisando outros composições de Lindberg, encontramos na peça ABLAUF (1983), o mesmo efeito, mas impresso da maneira descrita por Raasakka (2009).

O processo utilizado na pesquisa para o estudo deste efeito, se baseou em encontrar a nota mais aguda das parciais harmônicas e após a estabilização nesta nota, iniciar um movimento de relaxamento do maxilar e a abertura do trato vocal, causando assim, um glissando descendente até chegar na nota fundamental. Testamos o estudo partindo da fundamental até a nota mais 
aguda, mas esse procedimento não produziu o efeito desejado; notamos que quando realizado a abertura do trato vocal, com o objetivo de produzir o maior número de parciais juntas, soando em conjunto com a fundamental, ocorria um salto involuntário para as parciais mais agudas. Outra observação, foi que o volume de ar na boquilha não pode ser muito grande, pois não favorece uma vibração com uma amplitude necessária para palheta executar múltiplos sons, com o volume sonoro exigido.

\subsection{2 "Horn" efeito}

Não encontramos na bibliografia consultada esta terminologia, e considerou-se que este nome é dado a uma relação de semelhança entre a nota executada e o som de uma trompa. Este efeito aparece nos compassos 137, 167 e 428, sendo este último em uníssono com a primeira trompa da orquestra.

Figura 32 - Horn-effect with fingering

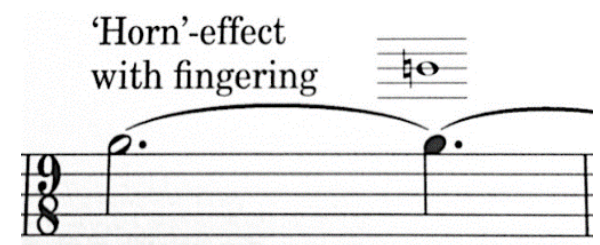

Fonte: LINDBERG, 2013, p. 6

Para realizar este efeito utilizamos a posição do Si4, como sugerido possivelmente pelo intérprete colaborador, e buscamos com uma alteração do trato vocal e na pressão da velocidade de ar reproduzir o efeito. Uma maneira que se apresentou eficiente no estudo deste efeito, foi a abertura do indicador da mão direita no ataque da nota. Desta maneira, foi possível realizar um ataque mais preciso, e logo após a produção da nota, voltamos com o dedo para a posição inicial, sugerida no texto musical. A teoria acústica deste efeito é igual ao que apresentamos na primeira dificuldade estudada, que consiste na utilização da mesma posição para gerar outras notas que são parciais da série harmônicos do instrumento. A ressonância deste efeito se mostrou de grande volume sonoro, não alcançado executando a nota musical na posição original. 


\subsubsection{Dentes na palheta}

Figura 33 - Compassos 550-556

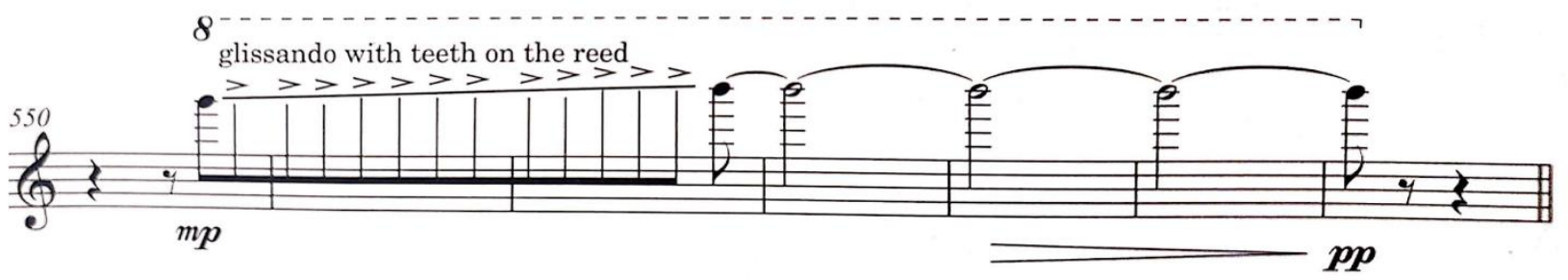

Fonte: LINDBERG, 2013, p. 23a

Como o termo indica, "glissando com dentes na palheta", envolve colocar o dentes inferiores levemente na palheta ao invés do lábio inferior. Isso pode estender o alcance do instrumento até como escrito para um Si 8. As notas realizadas com os dentes na palheta apresentam dificuldades no controle e precisão em sua execução. Para Rehfeldt (1994), isso não quer dizer que elas sejam inutilizáveis, mas é uma habilidade pouco explorada no estudo tradicional do instrumento, e sugere maneiras de como escrever o efeito,

Principalmente, as notas a serem tocadas com os dentes na palheta, são notadas usando um triângulo na cabeça da nota, apontando para cima e geralmente indicando para tocar a nota mais alta possível (de altura indeterminada). Uma instrução verbal é sempre necessária para especificar os dentes na palheta, já que uma cabeça de nota triangular sem nenhuma explicação pode ser interpretada como significando qualquer nota extremamente alta (Rehfeldt, 1994, p. 64, tradução nossa).

Figura 34 - Indicação de glissando segundo Rehfeldt

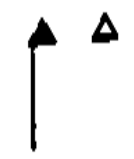

Fonte: $\mathrm{O}$ autor

Para realizar o glissando sugerido na partitura, propomos um estudo, onde é explorado uma movimentação dos dentes em diferentes regiões da palheta. Este estudo colaborou para um mapeamento da área da palheta que melhor responderia ao efeito desejado, e depois de identificar a posição adequada, foi aplicado em melodias simples como "Atirei o pau no gato" 
e "Parabéns para você" com este efeito, o que estimulou a formação de uma memória muscular, que contribuiu para a execução correta da proposta musical do compositor.

\subsubsection{Overtone glissando}

Na cadência escrita do concerto, Lindberg escreve um glissando utilizando o termo overtone, encontramos uma descrição deste efeito em Raasakka (2009):

Em notas graves, o clarinetista pode não apenas selecionar as parciais
individuais alterando a embocadura, como também executar um glissando
multifônico suave. Neste glissando as notas se movem de maneira fácil e em
grupos de mais de uma nota, enquanto a fundamental permanece estável. Um
glissando multifônico é executado mudando a posição da embocadura, sem
mudar o dedilhado, este efeito funciona melhor nas notas mais graves do
instrumento (Raasakka, 2009, p. 174, tradução nossa).

A descrição acima, nos faz refletir sobre um efeito já relatado neste trabalho, o Broken low Tones, agora com a adição dos glissandos.

Figura 35 - Compasso 529

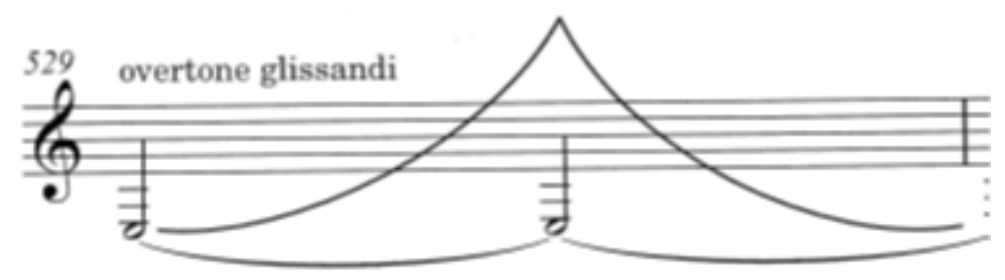

Fonte: LINDBERG, 2013, p. 22

Para realizar este efeito, foi proposto um estudo do movimento da mandíbula, da língua e dos lábios e este movimento favoreceu a realização do som exigido neste trecho. Para o estudo adotamos o seguinte procedimento: para o glissando com movimento ascendente, executamos o broken low tones com a língua na posição da vogal [o], com mandíbula baixa e os lábios relaxados, depois movimentamos a língua no sentido da vogal [i] e esticamos os lábios para a lateral (como em um sorriso). Para o movimento descendente do glissando foi aplicado a mesma técnica só que realizada em sentido contrário. 


\subsection{INTERFERÊNCIAS NO CONTEXTO DE TRABALHO}

Com a classificação das dificuldades, as escolha dos dedilhados e a identificação das maneiras de realizar as técnicas estendidas, buscamos algumas propostas de interferência ao contexto de trabalho que colaborassem com o processo de retenção do conhecimento adquirido. A primeira proposta foi criar um ambiente de trabalho onde a partitura do concerto poderia ser acessada a qualquer momento, para isso, cópias das partituras foram afixadas nas paredes do estúdio do pesquisador. Tanto a disposição dos excertos, quando a ordem de estudo não seguiram critério específico para sua execução, o que contribuiu para uma maior variedade e não repetição do material musical, anotações não foram economizadas bem como a quantidade de interferências do contexto musical.

Este procedimento foi utilizado até a retenção das informações e o desenvolvimento de uma fluência nos trechos de maior dificuldade. Após algumas partes já estarem decoradas, foi estimulado a execução do trecho, assim que montado o instrumento, sem nenhum aquecimento ou escolha de palheta. Notamos neste procedimento, que algumas passagens ainda não estavam interiorizadas pelo pesquisador, era necessário retomar o processo de estudo era retomado com o objetivo de compreender e assimilar a melhor maneira de reproduzir o trecho em questão.

Após a aquisição das competências necessárias nos trechos que apresentavam dificuldades, foi estimulado o estudo em diferentes espaços e salas. Com a possibilidade do acesso aos teatros São Pedro e Sérgio Cardoso - SP, foi explorado o estudo no palco com o objetivo de melhorar a projeção sonora e perceber como o material musical estudado responderia em um ambiente diferente do habitual. Algumas adaptações do equipamento, mais especificamente na resistência da palheta, mostraram-se acertadas, já que com a necessidade de um maior volume sonoro, a palheta utilizada no estúdio de estudo não respondeu da mesma maneira em um espaço maior. Foi necessário uma adequação das palhetas para produzir o mesmo resultado obtido em espaços menores, o que colaborou com uma melhor adaptação aos ensaios com a orquestra.

Alguns hábitos foram alterados pelo pesquisador durante o processo de estudo, mudanças como: inserção de uma alimentação balanceada e saudável, práticas regulares de atividade física, redução do consumo de álcool e maior atenção com as horas do sono. Estas práticas ao longo do processo se mostraram acertadas e alguns resultados foram notado, como a redução da fadiga durante o estudo, maior foco na resolução dos problemas técnicos e uma redução da ansiedade nos meses que antecederam o concerto Maciente (2016). 


\subsection{CADENZA IMPROVISADA}

O concerto possui duas cadenzas, sendo a primeira escrita pelo compositor e a segunda improvisada pelo performer. A cadenza escrita possui um caráter virtuosístico, onde Lindberg explora toda a tessitura da clarineta. Arpejos de grande extensão, glissandos em overtone (broken low tones), trechos com articulações rápidas, escalas cromáticas em semifusas na região aguda e saltos entre nota extremas, constituem o material musical da cadenza escrita.

Criada no período Barroco e transformada ao longo da história da música, a cadenza representa o momento de virtuosismos e exibicionismo do intérprete dentro da obra, segundo Zamacois (1979, p.213), "a cadência representou a renúncia, pelo compositor, de todos os seus privilégios, a favor da técnica do instrumentista, para que brilhasse executando as passagens e acrobacias que considerasse adequadas e melhor demonstrasse o seu virtuosismo". Para o estudo desta cadenza utilizamos as mesmas ferramentas dos trechos anteriores.

A improvisação proposta na segunda cadenza não é algo novo. Menuhin e Davis (1979), relatam que no período barroco o improviso era estimulado nas obras de Haendel e Corelli:

A chegada do solista virtuoso ampliou o papel da improvisação. Na ópera, o
cantor sempre tivera liberdade para embelezar uma ária ou conjunto, mas essa
liberdade chegou mais tarde para os instrumentistas. Mozart é um dos
primeiros verdadeiros mestres do momento que, em um concerto, é chamado
de cadenza, chegando antes do final tutti -que em italiano quer dizer "todos -
, quando a orquestra para, cabendo ao solista improvisar sobre temas e
figurações do movimento precedente. [...]. Usualmente a cadenza era inserida
no primeiro e último movimentos (Menuhin e Davis, 1979, p. 64).

A liberdade da improvisação do intérprete sobre a cadenza foi sendo delimitada ao decorrer da história. Sobre isso Albino (2009), descreve que a improvisação foi sendo substituída por cadenzas escritas pelos compositores:

[...] não demorou muito para que os futuros compositores passassem a escrever suas próprias cadenzas, principalmente quando perceberam nos executantes certo declínio na capacidade de improvisar. Beethoven foi o primeiro a fazer isso no Concerto para piano forte n. 5, em mi bemol maior, op. 73 (1809) - o Imperador. Gradualmente, os compositores foram adotando uma escrita musical extremamente precisa, abolindo qualquer espaço para a improvisação. Tal procedimento seguiu até o serialismo integral no século XX (Albino, 2009, p. 73)

A substituição da improvisação por cadenzas complexas e com uma escrita mais detalhada pelo compositor, acarretou ao intérprete a responsabilidade de executar o texto musical com rigor e fidelidade, Lima (2005) aponta que: 
$\mathrm{Na}$ tradição musical escrita observamos ainda o nascimento de um intérprete musical cada vez mais subjugado à partitura, afastado da prática improvisatória e da liberdade de expressão, costumes bastante freqüentes na tradição oral. Mesmo assim, os novos referenciais não foram capazes de excluir a cumplicidade participativa do intérprete no ato da execução e muito menos afastar as alterações performáticas oriundas de fatores históricoculturais introduzidos na sociedade (Lima, 2005, p. 20)

Apesar da restrição criativa imposta ao intérprete pela escrita detalhada, alguns clarinetistas mantiveram a sua autonomia criativa, escrevendo as suas próprias cadenzas. Carl Barmann (1810-1885) por exemplo, escreveu cadenzas para os concertos de Weber e Mozart, que foram publicadas e são utilizados até hoje como referência. A prática de elaboração de uma cadenza personalizada é algo usual por solistas atuais e estão registradas em gravações e concertos.

Antes do contato com o material impresso da obra, acreditávamos que o performer colaborador tivesse composto a sua própria cadenza e a executasse em todos os concertos, mas nas entrevistas consultadas do compositor, já mencionada nesta pesquisa, é elucidado que Kriikku improvisa em cada performance. Este fato foi constatado após a audição de 3 performances diferentes do intérprete, em que cada performance foi interpretada uma cadenza diferente.

Segundo as informações elencadas, observamos que ao sugerir uma cadenza improvisada, o compositor possibilita ao intérprete um instante para beneficiar-se de sua possibilidades criativas e expande a sua relação com este momento único da performance. Laboissière (2007) nos lembra que:

A música, caracterizada pela flexibilidade, pela instabilidade e pela mutabilidade, é um "território movediço" que coloca em confrontamento uma infinidade de signos produzidos, que, combinados entre si, têm o poder de agregar sentidos, de instaurar devires ou, ainda, induzir idéias e emoções, bem como limitar o espaço em que é sugerida uma fidelidade "absoluta" às idéias do compositor (Laboissière, 2007, p. 185).

As questões que surgiram durante o processo do estudo da improvisação nos levaram a refletir sobre como poderíamos apresentar uma material musical à altura das ideias do compositor e compreender que a improvisação não necessariamente precisaria seguir de maneira absoluta as ideias propostas no concerto. Com a liberdade oferecida ao intérprete e possibilitando uma co-autoria neste trecho do concerto, Lindberg não oferece somente ao intérprete colaborador a possibilidade de compartilhar as suas idéias, mas estende isso a outros 
instrumentistas e considerando a performance como um momento único e não possível de interação, compreendemos a importância de utilizar as percepções e as sensações acumuladas ao longo da performance, e direcioná-las para o momento do improviso. Sobre o envolvimento do intérprete na performance, Laboissière (2007, p. 74) acrescenta que: "o intérprete, no acontecimento musical, envolve-se, coloca-se em relação, mistura-se gera perspectiva de mudança e é afetado, surgindo assim o sentido no processo interpretativo, fruto de um conceito idealista".

O processo de estudo consistiu em estimular a prática da improvisação utilizando o material musical contido no concerto como provocador de novas idéias. Este estudo foi realizado intercalando os diferentes trechos da obra e as improvisações foram registradas em gravações de áudio. A análise do material coletado, colaborou na compreensão de quais possibilidades musicais poderiam enriquecer o improviso. Observamos que a possibilidade de apresentar outros elementos musicais, que fossem diferentes daqueles expostos pela cadenza escrita, tornaria a execução mais interessante e poderia auxiliar numa melhor conexão com a parte seguinte do concerto.

Compreendemos que o estudo da improvisação permite ao músico desenvolver mais regularmente a sua criatividade e que a prática habitual, colabora com o autoconhecimento das possibilidades criativas do instrumentista, aumentando assim sua gama de conhecimento. Albino (2009, p.165) acrescenta que "em muitos casos esse conhecimento não estará em livros, e sim na própria prática" e completa que “[...] a improvisação deverá ser um requisito importante para o desenvolvimento performático do músico, seja ele de que área for”.

O resultado de nosso trabalho para a cadenza improvisada pode ser constatado na gravação do concerto, apresentada como parte deste trabalho. 


\section{A PERFORMANCE DO CONCERTO}

A parte prática deste trabalho é constituída por uma apresentação do Concerto para Clarineta (2002) de Magnus Lindberg, realizada pelo pesquisador deste trabalho. Essa performance realizada no dia 17 de outubro de 2019, no Teatro Amazonas, com a Orquestra Amazonas Filarmônica, sob a regência de Guilherme Mannis.

Link da Performance: https://www.youtube.com/watch?v=gPHl_R1WQJQ

Figura 36 - Flyer de divulgação do concerto

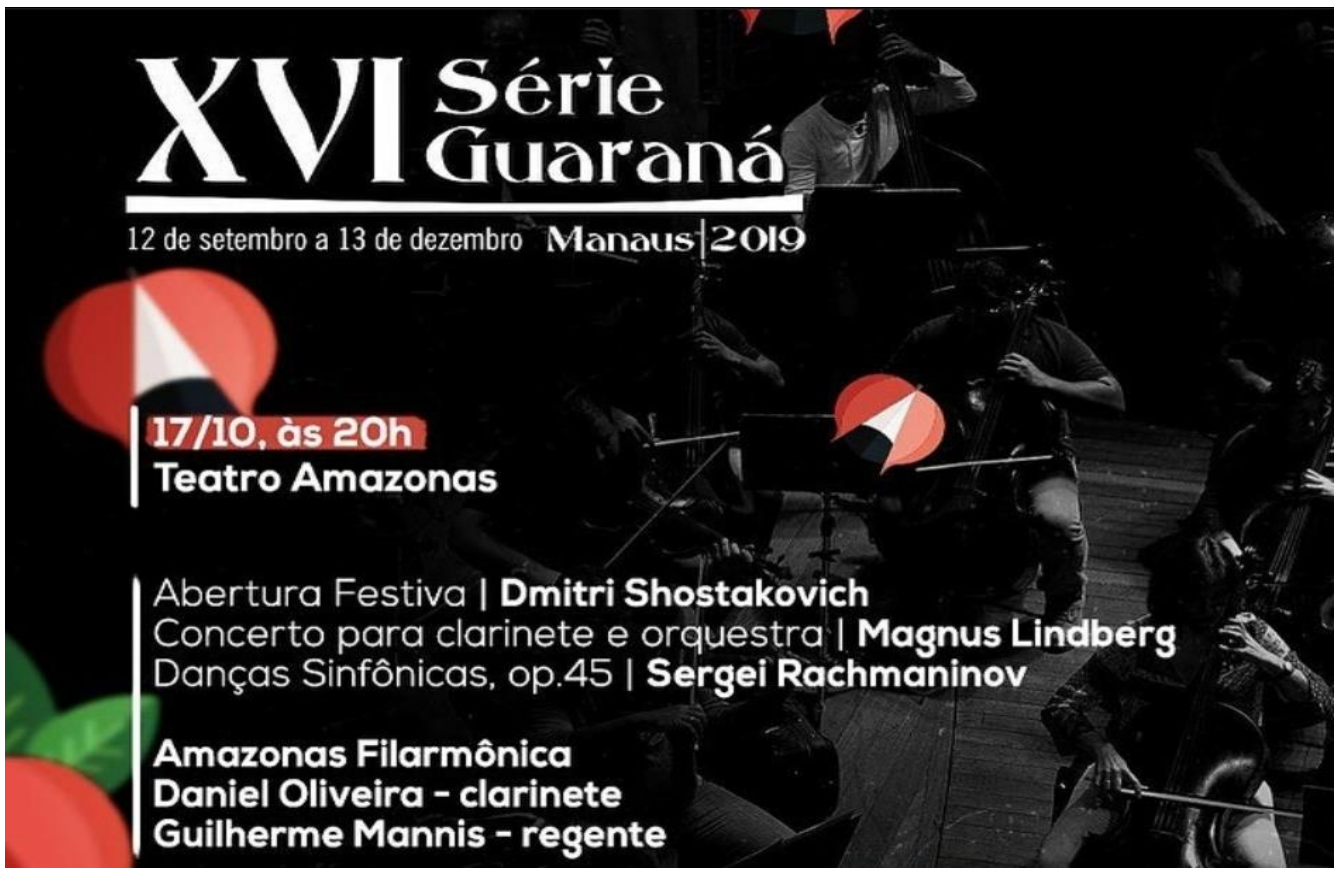

Fonte: Secretaria de Cultura e Economia Criativa do Estado do Amazonas 


\section{CONSIDERAÇÕES FINAIS}

Nesta pesquisa procurou-se identificar as colaborações entre compositores e intérpretes ao longo da história da clarineta e compreender como esta relação se desenvolve nos dias atuais. Observamos que a criação de ambientes que estimulem o diálogo e a troca de conhecimento entre compositores e intérpretes, favorecem a produção de um repertório novo e expandido em suas possibilidades técnicas e estéticas.

Entrar em contato com este repertório, onde todo o processo de composição foi desenvolvido em parceria e não somente com o objetivo de produzir uma peça mais idiomática pode apresentar muitos desafios, já que agrega propostas de sonoridades e técnicas, que para o intérprete colaborador são naturais. Para os intérpretes que desejam entrar em contato com este repertório, o grande desafio será a aquisição destas habilidades, o que poderá ser um enriquecedor processo de pesquisa e crescimento profissional e pessoal.

Durante o processo de aprendizado do Concerto para clarineta, valorizamos cada etapa do desenvolvimento e refletimos sobre as inúmeras maneiras de executar um determinado objeto musical ou técnica estendida. O relato dos caminhos empregados e as observações dos resultados, proporcionaram uma imersão nas múltiplas possibilidades da aquisição das novas técnicas e consideramos que este conhecimento compartilhado possa ser aproveitado não só para o estudo do Concerto mas também para outras obras contemporâneas.

Quando tocamos uma nova obra como o Concerto de Magnus Lindberg, devemos ter em mente que o instrumento que dispomos hoje para a performance é o mesmo acusticamente e ergometricamente para qual foram escritos os concertos de Nielsen (1928), Copland (1950), Françaix (1968) e Corigliano (1977). Assim, fica claro que quem deve se adaptar aos desafios é o intérprete, transformando sua técnica e sua abordagem no estudo, buscando soluções para a execução de sonoridades específicas e estéticas diferentes dos habituais. Neste caminho, é necessário refletir sobre sua formação e as maneiras como se realizam certos procedimentos técnicos, que por vezes podem ser considerados errados, como foi o caso deste intérprete, que mesmo depois de ter executado alguns destes concertos citados anteriormente, precisou aprender a articular o instrumento da maneira "correta", segundo a bibliografia consultada.

Compartilhamos também uma reflexão que este trabalho gerou sobre como seria o caminho de um processo de formação de um novo repertório: alguns intérpretes com habilidades individuais colaboram com compositores na elaboração de novas obras, outros 
intérpretes, com a necessidade de executar este repertório e no processo de adquirir essas habilidades, acabam encontrando outras soluções e adquirem outras habilidades. Desta forma, a maneira de tocar o instrumento vai se transformando.

Com todo esse estudo e aprofundamento das relações entre compositores e intérpretes, observamos a necessidade de desenvolver algo parecido no que diz respeito à vivência desta relação tão rica e desafiadora. Assim, idealizei um projeto cujo objetivo principal seria tornar mais denso o processo de construção de repertório, uma vez que em cada parceria é possível aprimorar a técnica e a percepção sobre performances de obras contemporâneas. O PandeMúsica, que conta com a participação dos clarinetistas Diogo Maia e Batista Jr., constituise de encomendas a compositores brasileiros de peças de 1 minuto de duração, para clarineta ou clarone solo, duos, trios, podendo ter inserção de sons pré gravados, edições, ou mesmo peças com propostas cênicas. Nesse momento de isolamento social, em que uma pandemia assola o planeta, propomos gravar estas obras em nossas casas e publicá-las em redes sociais como Youtube, Facebook e Instagram. Durante este processo contabilizamos 76 obras escritas em colaboração efetiva com os compositores. Após o término deste projeto, as composições serão editadas e disponibilizadas para a comunidade. 


\section{REFERÊNCIAS CONSULTADAS}

AFONSO, Luis Antonio Eugenio. "Dialogue de l'ombre double", de Pierre Boulez: abordagens interpretativas. 2006. 178 p. Tese (Doutorado em Música) - Universidade Estadual de Campinas, Instituto de Artes, Campinas, SP, 2006. Disponível em: http://www.repositorio.unicamp.br/handle/REPOSIP/284323. Acesso em: 27 out. 2017.

ALENCAR, Eunice M. L. Soriano de. Psicologia da criatividade. Porto Alegre: ArtesMédicas, 1986.

BAINES, Anthony. Wood wind instruments and their history. London: Dover, 1991.

BIRSAK, Kurt. The clarinet: a cultural history. Buchloe: Druck und Obermayer, 1994.

BRYMER, Jack. Clarinet. London: Kahn \& Averil, 1990.

CLARINET Concerto - Magnus Lindberg; [Manaus], 2019. 1 vídeo. Publicado pelo canal Daniel Oliveira. Disponível em: https://youtu.be/gPHl_R1WQJQ. Acesso em: 17 out. 2019.

CONE, Edward T. The pianist a as critic. In: The practice of performance: studies in musical interpretations. London: Cambridge University, 1995.

DOMENICI, Catarina Leite. It takes two to tango: a prática colaborativa na música contemporânea. Revista do Conservatório de Música da UFPel, Pelotas, n. 6, p. 1-14, 2013.

ERICSSON, K. Anders; KRAMPE, Ralf; TESCH-ROMER, Clemens. The role of deliberate practice in the acquisition of expert performance. Psychological Review, v. 100, n. 3, p. 363406, 1993. DOI:_10.1037//0033-295X.100.3.363. Disponível em: https://www.researchgate.net/publication/224827585_The_Role_of_Deliberate_Practice_in the_Acquisition_of_Expert_Performance. Acesso em : 2 jan. 2020.

HYLLEGARD, Randy; BORIES, Tamara L.. Deliberate practice theory: relevance, effort, and inherent enjoyment of music practice. Perceptual and Motor Skills, v. 107, n. 2, p. 439448 2008. DOI:_https://doi.org/10.2466/pms.107.2.439-448. Disponível em: https://journals.sagepub.com/doi/10.2466/pms.107.2.439-

448\#articleCitationDownloadContainer. Acesso em: 2 jan. 2020.

GARBOSA, Guilherme Sampaio. Concerto (1988) para clarineta de Ernst Mahle: um estudo comparativo de interpretações. 2002. Tese (Doutorado em Música) - Universidade Federal da Bahia, Escola de Música, Salvador, BA, 2002.

GIBSON, O. Lee. Clarinet acoustics. Bloomington: Indiana University, 1991. 
HAYDEN, Sam; WINDSOR, Luke. Collaboration and the composer: case studies from the end of the 20th century. Tempo, Cambridge, v. 61, n. 240, p. 28-39, 2007.

HELENO, Marcelo. Desenhos gráficos de clarinetes, 2005. 15 ilustrações.

HOEPRICH, Eric. The clarinet. London, Yale University, 2008.

HOSFIELD, Patrick. Music at The Mission: night ferry. Cabrillo Music, $2017 . \quad$ Disponível em: http://www.cabrillomusic.org/index.php?option=com_content $\&$ id=719/?s=2 013. Acesso em: 2 jun. 2017.

JOHNSTON, P. The practice revolution. Austrália: PracticeSpot, 2002.

JOHN, Rink. Analysis and (or?) performance. In: Rink, J. (ed). Musical performance: a guide to understanding. Tradução de Zélia Chueke. Cambridge: Cambridge University, 2002, p. 35-58.

JOHN-STEINER, Vera. Creative collaboration. New York: Oxford University, 2000.

KAGEYAMA, N. How many hours a day should you practice? Bulletproofmusician, 2020. Disponível em:

http://www.bulletproofmusician.com/how-many-hours-a-day-should-youpractice/. Acesso em: 2 jan. 2020.

KARI Kriikku, clarinet. ONDINE. Disponível em: https://www.ondine.net/index.php?lid=en\&cid=3.2\&oid=527. Acesso em: 19 ago. 2018.

KROLL, O., Morris, H.; BAINES, A. The clarinet: Rev., and with a repertory, by Diethard Riehm. London: B.T. Batsford, 1968.

LABOISSIÈRE, Marília. Interpretação musical: a dimensão recriadora da "comunicação" poética. São Paulo, Annablume, 2007. 195 p. Originalmente apresentado como tese de doutorado, Pontifícia Universidade Católica de São Paulo, 2002.

LAWSON, Colin. The Cambridge Companion to the clarinet. Cambridge: Cambridge University, 1995.

LAWSON, Colin. The early clarinet a practical guide. Cambridge, UK: Cambridge University, 2000.

THE LEGENDARY TOIMII Ensemble. Karttunen, 2019. Disponível em: http://www.karttunen.org/home.html/Toimii.html. Acesso em: 2 jun. 2019.

LIMA, Sonia Albano de. O virtual e o Real da Interpretação musical. In: (org.).

Uma metodologia de interpretação musical. São Paulo: Musa, 2005.

LINDBERG, Magnus. Clarinet concert. [London], Boosey \& Hawkes, 2013. 1 partitura [31 p.]. Clarineta. 
LINDBERG, Magnus. [São Paulo]. 1 vídeo. 2012. Ensaio Osesp - Orquestra interpreta "Concerto para clarinete de Magnus Lindberg. [Entrevista cedida à] Arthur Nestrovski. Publicado pelo canal Osesp. Disponível em: https://www.youtube.com/watch?v=HW6aOevetuM. Acesso em: 19 ago. 2018.

LINDBERG, Magnus. [S 1.: s. n.], 2018. 1 vídeo. Interview with Magnus Lindberg. Publicado pelo canal Metropolitana vídeos. Disponível em: https://www.youtube.com/watch?v=-9k1WImYDY. Acesso em: 19 ago. 2018.

LORENZI, Antoine; TRIGUEIROS-CUNHA, Nuno. Psicoacústica. Voyage au centre de l'audition, 2018. Disponível em: http://www.cochlea.eu/po/som/psicoacustica. Acesso em: 9 fev. 2018.

MACIENTE, Meryelle Nogueira. ZANI NETTO, Amílcar (orient). Estratégias de enfrentamento para a ansiedade de performance musical (APM): um olhar sobre músicos profissionais de orquestras paulistas. São Paulo, 2016. 327 p.

MAGNUS Lindberg Clarinet Concerto. Kari Kriikku Clarinettist, 2019. Disponível em: http://www.karikriikku.com/?page_id=287. Acesso em: 2 jun. 2019.

MENUHIN, Yehudi; DAVIS, Curt W. A música do homem. São Paulo: Martins Fontes, 1981.

MENEZES, Fabiano. A escrita idiomática em obras para trompa de Blauth, Lacerda, Mendes, Ficarelli. 2010. Dissertação (Mestrado em Música) - Programa de Pós-Graduação em Música, Centro de Letras e Artes, Universidade Federal do Estado do Rio de Janeiro, Rio de Janeiro, RJ, 2010.

MYERS, Arnold. Catalogue of the Edinburgh University Collection of Historic Musical Instruments. Edinburg: Edinburgh University Collection of Musical Instruments, 2007.

NIELSEN, S.G. Self-regulating learning strategies instrumental music practice.

Music Education Research, v. 3 n. 2, p. 155-67, 2001.

PINO, David. The clarinet and clarinet playing. Nova Iorque: C. Scribners`s Sons, 1980.

PINTO, Nuno Fernandes. A influência dos clarinetistas no desenvolvimento do clarinete e do seu repertório. 2006. Dissertação (Mestrado em Música) - Universidade de Aveiro, Departamento de Comunicação e Artes, Aveiro, 2006.

RAASAKKA, Mikko. Exploring the clarinet: a guide to clarinet technique and finnish clarinet music. Helsinki: Fennica Gehrman, 2010.

RAY, Sonia. Colaboração Compositor-Performance no Século XXI: uma ideia de trajetória e algumas perspectivas. In: CONGRESSO DA ASSOCIAÇÃO NACIONAL DE PESQUISA E PÓS-GRADUAÇÃO EM MÚSICA, 20, 2010, Florianópolis. Anais do XX Congresso da ANPPOM. Florianópolis: Universidade do Estado de Santa Catarina, 2010, p. 1310-1314.

REHFELDT, Phillip. New directions for clarinet. Revised Edition. Lanham: Scarecrow, 2003. 
RENDALL, F. Geoffrey. History and construction. Nova Iorque: Norton, 1971.

RICE, Albert R. The baroque clarinet. Oxford: Clarendon, 1992.

RIPP, David. Pesquisa-ação: uma introdução metodológica. Educ. Pesqui., São Paulo, v. 31, n. 3, p. 443-466, dez. 2005. DOI: https://doi.org/10.1590/S1517-97022005000300009 - Disponível em: http://www.scielo.br/scielo.php?script=sci_arttext\&pid=S151797022005000300009\&lng=en\&nrm=iso. Acesso em: 2 jan. 2020.

WESTON, Pamela. Clarinet virtuosi of the past. York: Emerson, 1971.

WESTON, Pamela. The clarinettist's companion. Northants: Fentone Music, 1976.

WESTON, Pamela. Playes and composers. In: LAWSON, Colin. The Cambridge Companion to the clarinet. Cambridge: Cambridge University, 1995, p. 92-106.

WILLIAMON, A. Musical excellence: strategies and techniques to enhance performance. Oxford: Oxford University, 2004.

ZAMACOIS, Joaquín. Curso de formas musicales. Barcelona: Labor, 1979. 


\section{APÊNDICE A - TABELA DE COLABORAÇÃO COMPOSITOR / INTÉRPRETE / OBRAS}

\begin{tabular}{|c|c|c|}
\hline COMPOSITOR & CLARINETISTA & OBRAS \\
\hline $\begin{array}{l}\text { Johann Melchior (1696- } \\
\text { 1765) }\end{array}$ & $\begin{array}{l}\text { Johann Reusch Molter (1710- } \\
\text { 1787) }\end{array}$ & 6 concertos \\
\hline $\begin{array}{l}\text { Carl Stamitz (1745- } \\
1801)\end{array}$ & Joseph Beer (1744-1812) & $\begin{array}{l}\text { Dos } 11 \text { concertos seis foram escritos para o } \\
\text { clarinetista Beer }\end{array}$ \\
\hline \multirow[t]{2}{*}{$\begin{array}{l}\text { W. A. Mozart (1756- } \\
\text { 1791) }\end{array}$} & Anton Stadler (1753-1812) & $\begin{array}{l}\text { Concerto para clarineta e orquestra em Lá maior } \\
\text { K. } 662 \\
\text { Quinteto para clarineta e cordas, K. } 581 \text { e Trio } \\
\text { para clarineta, viola e piano, K. } 498 .\end{array}$ \\
\hline & Joseph Bahr (1770-1819) & $\begin{array}{l}\text { Quinteto, op. } 16 \text { para piano e sopros; Sexteto, } \\
\text { op. } 71 \text {; Septeto, op. } 20 \text {; Trio, op. } 11 .\end{array}$ \\
\hline \multirow[t]{2}{*}{ L. Spohr (1784-1859) } & $\begin{array}{l}\text { Joseph Friedlowsky } \\
(1777-1859)\end{array}$ & Octeto, op. 32. \\
\hline & $\begin{array}{l}\text { Simon Hermstedt } \\
(1778-1846)\end{array}$ & $\begin{array}{l}\text { Concerto, op. 26, n.1; Concerto, op. 57, n. } 2 \text {; } \\
\text { Concerto, WoO. 19, no. } 3 \text { e Concerto, WoO. } 20 \text {, } \\
\text { n. } 4 .\end{array}$ \\
\hline $\begin{array}{l}\text { C. M. von Weber } \\
(1786-1826)\end{array}$ & $\begin{array}{l}\text { Heinrich Baermann } \\
(1784-1847)\end{array}$ & $\begin{array}{l}\text { Concertino, op. 26; Concerto, op. } 73 \text {, n. 1; } \\
\text { Concerto, op. } 74 \text {, n. 2; Quinteto para clarinete e } \\
\text { cordas, op. } 34 \text { e Gran duo concertante }\end{array}$ \\
\hline $\begin{array}{l}\text { Gioachino Rossini } \\
(1792-1868)\end{array}$ & Valentin de Lapelouze & $\begin{array}{l}\text { Introdução, tema e variação e Fantasia para } \\
\text { clarineta e piano. }\end{array}$ \\
\hline $\begin{array}{l}\text { Johannes Brahms } \\
(1833-1897)\end{array}$ & $\begin{array}{l}\text { Richard Muhlfeld } \\
(1859-1907)\end{array}$ & $\begin{array}{l}\text { Trio para clarineta, Violoncelo e piano, op. } 114 \text {; } \\
\text { Quinteto para clarinete e cordas, op. } 115 ; 2 \\
\text { Sonatas para clarinete e piano, op. } 120 \text { e op. } 12\end{array}$ \\
\hline
\end{tabular}




\begin{tabular}{|c|c|c|}
\hline $\begin{array}{l}\text { Carl Nielsen } \\
(1865-1931)\end{array}$ & Aage Oxenvad (1884-1944) & $\begin{array}{l}\text { Quinteto de sopros; Serenata in vano para } \\
\text { trompa, clarineta, fagote, violoncelo e } \\
\text { contrabaixo e concerto, op. } 57\end{array}$ \\
\hline $\begin{array}{l}\text { Bela Bartók } \\
(1881-1945)\end{array}$ & $\begin{array}{l}\text { Benny Goodman } \\
(1909-1986)\end{array}$ & Contrastes para violino, clarinete e piano \\
\hline $\begin{array}{l}\text { Igor Stravisnky (1882- } \\
\text { 1971) }\end{array}$ & Werner Reinhart (1884-1951) & $\begin{array}{l}3 \text { peças solo e a versão para clarineta, violino e } \\
\text { piano da "História do Soldado" }\end{array}$ \\
\hline $\begin{array}{l}\text { Igor Stravinsky } \\
(1882-1971)\end{array}$ & $\begin{array}{l}\text { Woody Herman } \\
(1913-1987)\end{array}$ & Ebony concerto \\
\hline $\begin{array}{l}\text { Arthur Honegger (1892- } \\
1955)\end{array}$ & Werner Reinhart (1884-1951 & Sonatina \\
\hline $\begin{array}{l}\text { Darius Milhaud } \\
(1892-1974)\end{array}$ & $\begin{array}{l}\text { Louis Cahuzac } \\
(1880-1960)\end{array}$ & Duo concertante e sonatina \\
\hline $\begin{array}{l}\text { Paul Hindemith } \\
(1895-1963)\end{array}$ & Werner Reinhart (1884-1951) & Quinteto \\
\hline $\begin{array}{l}\text { Francisco Mignone } \\
(1897-1986)\end{array}$ & José Botelho (1931-) & Concertino \\
\hline $\begin{array}{l}\text { Gerald Finzi } \\
(1901-1956)\end{array}$ & $\begin{array}{l}\text { Frederick Thurston } \\
(1901-1953)\end{array}$ & Concerto, op. 31 \\
\hline $\begin{array}{l}\text { Malcolm Arnold } \\
(1921-2006)\end{array}$ & & Concerto n. 1, op. 20 \\
\hline $\begin{array}{l}\text { Aaron Copland } \\
(1900-1990)\end{array}$ & $\begin{array}{l}\text { Benny Goodman } \\
(1909-1986)\end{array}$ & Concerto \\
\hline $\begin{array}{l}\text { Morton Gould } \\
(1913-1996)\end{array}$ & $\begin{array}{l}\text { Benny Goodman } \\
(1909-1986)\end{array}$ & Derivations; Benny’s gig \\
\hline $\begin{array}{l}\text { Isang Yun } \\
(1917-1995)\end{array}$ & $\begin{array}{l}\text { Eduard Brunner } \\
(1939-2017)\end{array}$ & Concerto \\
\hline $\begin{array}{l}\text { Isang Yun } \\
(1917-1995)\end{array}$ & $\begin{array}{l}\text { Harry Sparnaay } \\
(1944-2017)\end{array}$ & Monólogo para clarone solo \\
\hline
\end{tabular}




\begin{tabular}{|c|c|c|}
\hline $\begin{array}{l}\text { Claudio Santoro (1919- } \\
\text { 1989) }\end{array}$ & $\begin{array}{l}\text { Luiz Gonzaga Carneiro (1928- } \\
\text { 2007) }\end{array}$ & 3 peças solo; Fantasia Sul América \\
\hline $\begin{array}{l}\text { Malcolm Arnold } \\
(1921-2006)\end{array}$ & $\begin{array}{l}\text { Benny Goodman } \\
(1909-1986)\end{array}$ & Concerto n. 2 \\
\hline \multirow[t]{2}{*}{$\begin{array}{l}\text { Pierre Boulez } \\
(1925-2016)\end{array}$} & $\begin{array}{l}\text { Hans Deinzer } \\
(1934-\end{array}$ & Domaines \\
\hline & Alains Damiens (1950- & Dialogue de l'ombre Double \\
\hline $\begin{array}{l}\text { Karlheinz Stockhausen } \\
(1928-2007)\end{array}$ & $\begin{array}{l}\text { Susanne Stephens } \\
(1946-)\end{array}$ & $\begin{array}{l}\text { Harlekin; Der kleine Harlekin; Amour; In } \\
\text { freundschaft }\end{array}$ \\
\hline $\begin{array}{l}\text { Robert Muczynski } \\
(1929-2010)\end{array}$ & $\begin{array}{l}\text { Mitchel Lurie } \\
(1922-2008)\end{array}$ & Time pieces \\
\hline $\begin{array}{l}\text { Toru Takemitsu } \\
(1930-1996)\end{array}$ & $\begin{array}{l}\text { Richard Stoltzmann } \\
(1942-)\end{array}$ & Waves concerto \\
\hline John Corigliano (1938 -) & Stanley Drucker (1929 -) & Concerto \\
\hline
\end{tabular}


APÊNDICE B - PLANO DE TRABALHO

\begin{tabular}{|c|c|c|c|}
\hline Período & Tarefa & Procedimento & Resultado \\
\hline $\begin{array}{l}\text { agosto, } \\
\text { setembro e } \\
\text { outubro - } \\
2018\end{array}$ & $\begin{array}{lr}\text { Leitura do concerto e } \\
\text { classificação das principais } \\
\text { dificuldades } & \text { e } \\
\text { competências } & \text { necessárias } \\
\text { para a } & \text { execução; } \\
\text { desenvolver uma rotina } \\
\text { diária. }\end{array}$ & $\begin{array}{l}\text { Fazer cópias de } \\
\text { partituras, utilizar cores } \\
\text { para classificar as } \\
\text { dificuldades. } \\
\text { Definir métodos de } \\
\text { técnicas básicas. }\end{array}$ & $\begin{array}{l}3 \text { cópias, todas classificadas. } \\
\text { Rotina de } 1 \text { h e } 30 \text { min. de notas } \\
\text { longas, afinação e vocalização de } \\
\text { arpejos. }\end{array}$ \\
\hline $\begin{array}{l}\text { novembro, } \\
\text { dezembro de } \\
2018 \text { e } \\
\text { janeiro de } \\
2019\end{array}$ & $\begin{array}{l}\text { Pesquisa de métodos, } \\
\text { técnicas, gravações } \mathrm{e} \\
\text { material escrito sobre o } \\
\text { concerto ou sobre o } \\
\text { relacionamento } \\
\text { intérprete do } \\
\text { compositor; Rotina de } \\
\text { alimentação, } \\
\text { atividade sono, } \\
\text { meditação. }\end{array}$ & $\begin{array}{l}\text { Audição crítica da } \\
\text { gravação da performance } \\
\text { do Intérprete colaborador. } \\
\text { Leitura de trabalhos sobre } \\
\text { a análise musical do } \\
\text { concerto. Observação de } \\
\text { outras obras escritas } \\
\text { como resultado da } \\
\text { colaboração. } \\
\text { Criar bons hábitos e } \\
\text { dormir. }\end{array}$ & $\begin{array}{l}\text { Compreensão dos principais pontos } \\
\text { onde ocorreu uma colaboração } \\
\text { efetiva, } \\
\text { Compreensão harmônica e } \\
\text { fraseológica da obra }\end{array}$ \\
\hline $\begin{array}{l}\text { fevereiro } \\
2019\end{array}$ & Avaliação dos resultados. & $\begin{array}{l}\text { Consulta às anotações } \\
\text { diárias. }\end{array}$ & Rever os andamentos. \\
\hline $\begin{array}{l}\text { fevereiro, } \\
\text { março e } \\
\text { abril de } \\
2019\end{array}$ & $\begin{array}{l}\text { Aplicação do material } \\
\text { selecionado e estudo das } \\
\text { principais dificuldades, } \\
\text { empregando o método } \\
\text { (CIE); estabelecer a rotina } \\
\text { proposta. }\end{array}$ & $\begin{array}{l}\text { Colar as partituras em } \\
\text { diferentes ordens no } \\
\text { estúdio do pesquisador. } \\
\text { Realizar variadas } \\
\text { interferências no contexto } \\
\text { musical. Estudar outras } \\
\text { abordagens para } \\
\text { articulação. } \\
\text { Correr e comer melhor. }\end{array}$ & $\begin{array}{l}\text { Começamos a decorar alguns trechos } \\
\text { complicados. Melhora no sono e na } \\
\text { ansiedade. }\end{array}$ \\
\hline $\begin{array}{l}\text { maio, junho } \\
\text { e julho } 2019\end{array}$ & $\begin{array}{l}\text { Avaliação dos trechos já } \\
\text { estudados, manter rotinas } \\
\text { e estudos de improvisação } \\
\text { e articulação. }\end{array}$ & $\begin{array}{l}\text { Alguns trechos com } \\
\text { problemas, precisa voltar } \\
\text { para o processo de } \\
\text { interferência e retenção. } \\
\text { Método de articulação. }\end{array}$ & $\begin{array}{l}\text { Articulação preocupa, é muito } \\
\text { rápido. Alguns trechos inseguros, } \\
\text { ansiedade e medo de falhar. Cadenza } \\
\text { sem conexão entre ela e } \\
\text { desconstruída. }\end{array}$ \\
\hline $\begin{array}{l}\text { agosto de } \\
2019\end{array}$ & $\begin{array}{l}\text { Estudar em outros } \\
\text { ambientes, selecionar } \\
\text { palhetas, começar a tocar } \\
\text { o concerto todo, cadenza e } \\
\text { aumentar o tempo de } \\
\text { meditação. }\end{array}$ & $\begin{array}{l}\text { Estudo no Teatro Sérgio } \\
\text { Cardoso, tocar grandes } \\
\text { sessões sem errar. Gravar } \\
\text { a cadenza. Sentir o corpo } \\
\text { e a respiração }\end{array}$ & $\begin{array}{l}\text { Muito grande a sala, nenhuma } \\
\text { palheta funcionou. Cadenza ainda } \\
\text { com medo, (deu branco) quando } \\
\text { precisou gravar. } \\
\text { Corpo cansado com a necessidade de } \\
\text { emitir mais som }\end{array}$ \\
\hline $\begin{array}{l}\text { setembro de } \\
2019\end{array}$ & $\begin{array}{l}\text { Não estudar mais em } \\
\text { ambientes pequenos, } \\
\text { Preparar muitas palhetas, } \\
\text { relaxar e tocar o concerto } \\
\text { inteiro sem parar. }\end{array}$ & $\begin{array}{l}\text { Estudo no Teatro Sérgio } \\
\text { Cardoso e no São Pedro } \\
\text { (tamanho igual ao da } \\
\text { performance) preparo de } \\
30 \text { palhetas que } \\
\text { funcionam, entre palhetas }\end{array}$ & $\begin{array}{l}\text { Trechos fluente, a articulação está } \\
\text { quase, melhora na qualidade do som } \\
\text { e segurança em tocar em ambientes } \\
\text { maiores, palhetas em processo, } \\
\text { algumas morrem, o concerto exige }\end{array}$ \\
\hline
\end{tabular}




\begin{tabular}{|c|c|c|c|}
\hline & & $\begin{array}{l}\text { para ambiente seco e } \\
\text { outras para ambiente com } \\
\text { reverberação. }\end{array}$ & $\begin{array}{l}\text { muito (super agudos, articulações e } \\
\text { overdrive. }\end{array}$ \\
\hline $\begin{array}{l}\text { Dias } 1 \text { a } 6 \text { de } \\
\text { outubro de } \\
2019\end{array}$ & $\begin{array}{l}\text { Tocar o concerto quantas } \\
\text { vezes for possível, tocar } \\
\text { para amigos e colegas, } \\
\text { melhorar as palhetas. } \\
\text { Intensificar a meditação e } \\
\text { o sono. }\end{array}$ & $\begin{array}{l}\text { Estudo somente no palco } \\
\text { do São Pedro, sempre } \\
\text { tocando inteiro! Palhetas, } \\
\text { preparar mais. Tentar } \\
\text { dormir mais - ansiedade. }\end{array}$ & $\begin{array}{l}\text { Melhor controle do som no ambiente } \\
\text { maior, poucas coisas inseguras }\end{array}$ \\
\hline $\begin{array}{l}\text { Dias } 7 \text { a } 12 \\
\text { de outubro } \\
\text { de } 2019\end{array}$ & $\begin{array}{l}\text { Simulados, reduzir tempo } \\
\text { de estudo e controlar } \\
\text { ansiedade. Palhetas. }\end{array}$ & $\begin{array}{l}\text { Tocar somente o concerto } \\
\text { muitas vezes, quando } \\
\text { cansar pare. Toque com } \\
\text { palhetas ruins, toque } \\
\text { deitado no chão, suba } \\
\text { escadas e toque, toque } \\
\text { assistindo vídeo no } \\
\text { youtube sobre qualquer } \\
\text { coisa. } \\
\text { Medite - respirar fundo. }\end{array}$ & $\begin{array}{l}\text { As passagens musicais estão } \\
\text { assimiladas, precisa relaxar. Estou } \\
\text { cansado. }\end{array}$ \\
\hline $\begin{array}{l}13 \text { de } \\
\text { outubro de } \\
2019\end{array}$ & Descanso. & Descanso. & Descanso. \\
\hline $\begin{array}{l}14 \text { de } \\
\text { outubro de } \\
\text { outubro/ } \\
\text { Viagem para } \\
\text { Manaus }\end{array}$ & $\begin{array}{l}\text { Estudo no Theatro São } \\
\text { Pedro parte da manhã - } \\
\text { Tocar } 3 \text { vezes o concerto } \\
\text { inteiro. }\end{array}$ & $\begin{array}{l}\text { Sem errar e sentindo o } \\
\text { corpo, imaginando que } \\
\text { está em Manaus. }\end{array}$ & Positivo, tudo pronto. \\
\hline $\begin{array}{l}15 \text { de } \\
\text { outubro de } \\
2019- \\
\text { Manaus }\end{array}$ & $\begin{array}{l}\text { Chegar cedo no Teatro - } \\
\text { tocar notas longas no } \\
\text { palco - palhetas/ primeira } \\
\text { leitura/ estudo na parte da } \\
\text { tarde. }\end{array}$ & $\begin{array}{l}\text { Relaxar, sentir a acústica, } \\
\text { sentir a palhetas/ nervoso } \\
\text { para o ensaio, a formação } \\
\text { do concerto exige uma } \\
\text { orquestra enorme. }\end{array}$ & $\begin{array}{l}\text { Algumas coisas não tão boas! } \\
\text { Nervoso por conta dos colegas, O } \\
\text { Maestro ajudou muito, sempre } \\
\text { fazendo música juntos. Muitos } \\
\text { comentários: "esse concerto é } \\
\text { impossível", "como alguém } \\
\text { consegue tocar isso", "nunca vi } \\
\text { alguém tocando assim". A orquestra } \\
\text { gostou do concerto, não é um } \\
\text { acompanhamento é música para } \\
\text { todos. }\end{array}$ \\
\hline $\begin{array}{l}16 \text { de } \\
\text { outubro }\end{array}$ & $\begin{array}{l}\text { Chegar cedo, tocar notas } \\
\text { longas no palco - ficar } \\
\text { tranquilo/ estudar a tarde. }\end{array}$ & $\begin{array}{l}\text { Só tocar, / estudar } \\
\text { algumas passagens sem } \\
\text { culpa ou compromisso, } \\
\text { tocar o concerto um tom } \\
\text { acima. }\end{array}$ & $\begin{array}{l}\text { Muito melhor, tudo caminhando, } \\
\text { orquestra entendendo melhor a sua } \\
\text { função de solista também. }\end{array}$ \\
\hline $\begin{array}{l}17 \text { de } \\
\text { outubro de } \\
2019 \text { - Parte } \\
\text { da manhã }\end{array}$ & $\begin{array}{l}\text { Ensaio Geral - tocar duas } \\
\text { vezes. }\end{array}$ & $\begin{array}{l}\text { Sem preocupação esse é } \\
\text { o momento de errar. }\end{array}$ & $\begin{array}{l}\text { Algumas coisas se desencontraram, } \\
\text { mas soubemos resolver. Apesar } \\
\text { disso estamos confiantes. Descansar. }\end{array}$ \\
\hline $\begin{array}{l}17 \text { de } \\
\text { outubro de } \\
2019 \text { - Parte } \\
\text { da noite }\end{array}$ & Concerto. & Concerto. & Concerto. \\
\hline
\end{tabular}




\section{ANEXOS - PARTITURA DO CONCERTO PARA CLARINETA DE MAGNUS LINDBERG}

IMPORTANT NOTICE: The unauthorised copying of the whole or any part of this publication is illegal

\section{Dedicated to Kari Kriikku \\ CLARINET CONCERTO}
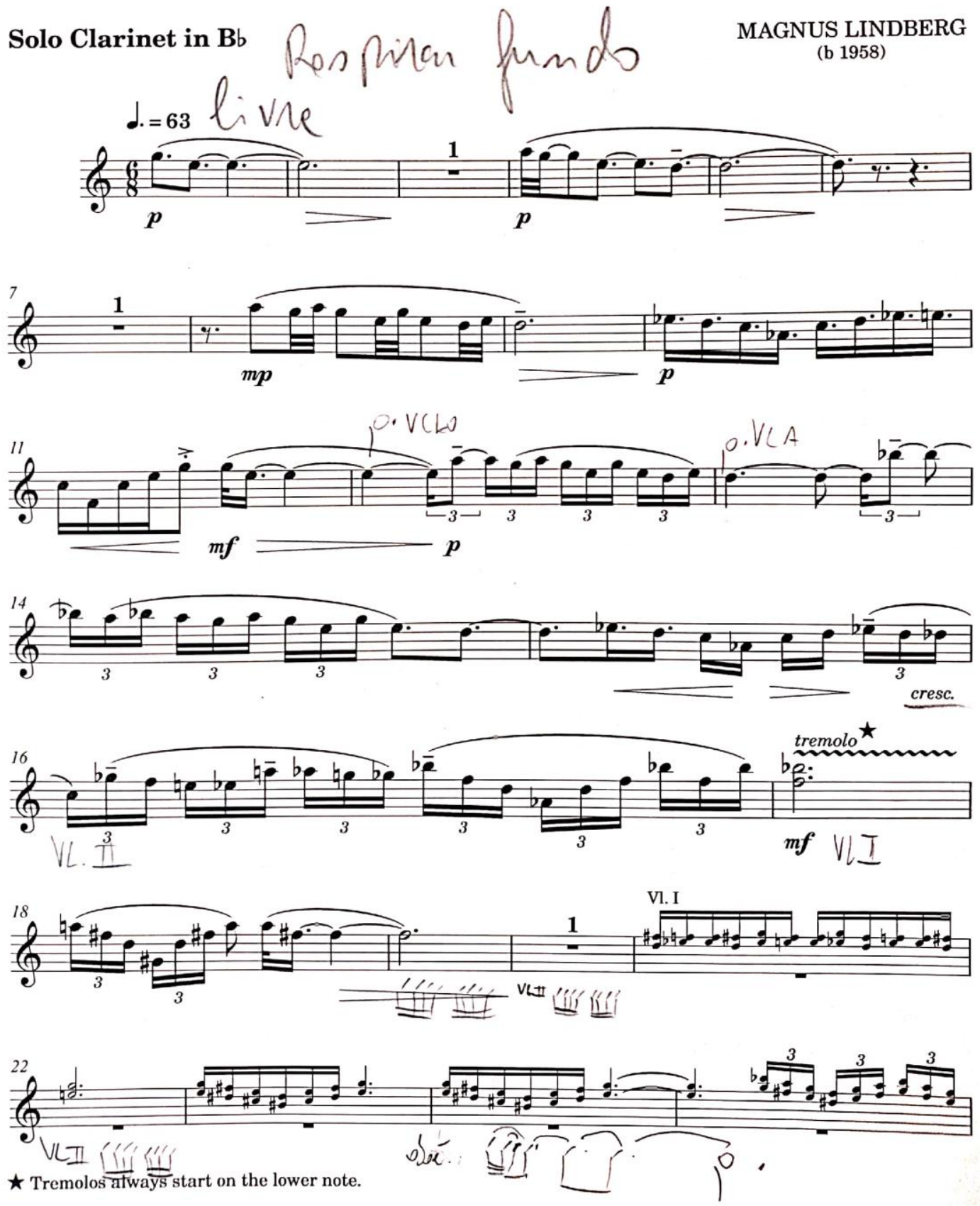

(1) Copyright 2002, 2013 by Boosey \& Hawkes Music Publishers Ltd 
2
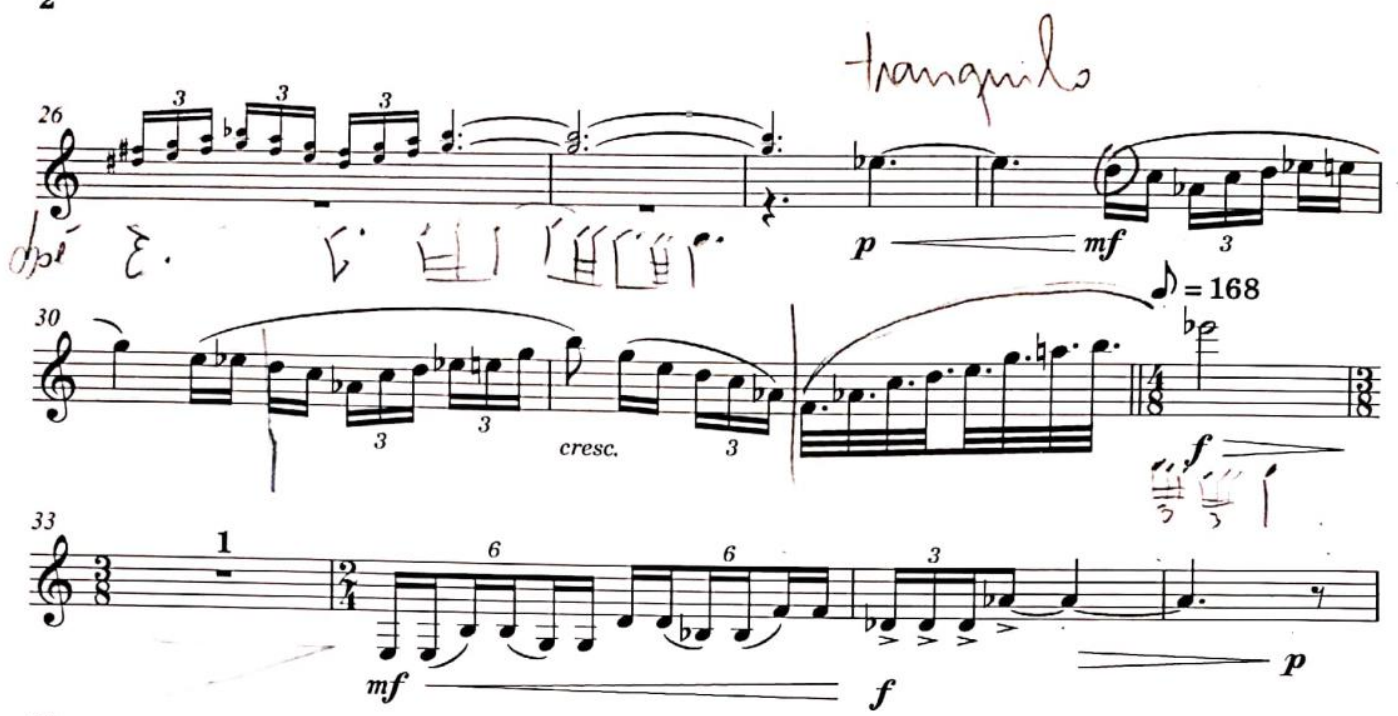

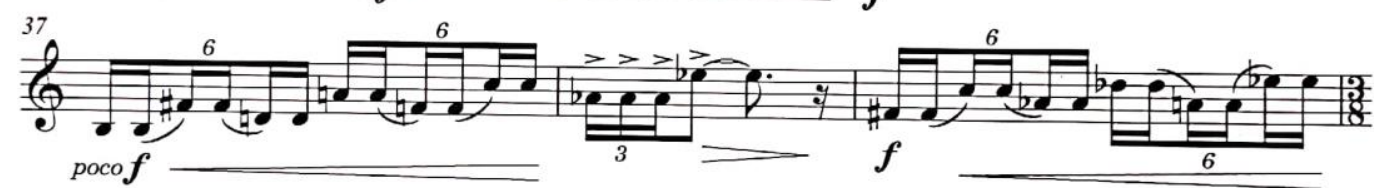

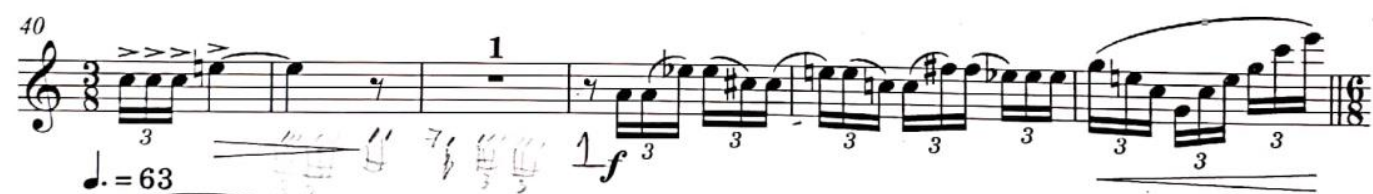

moltof $=26$
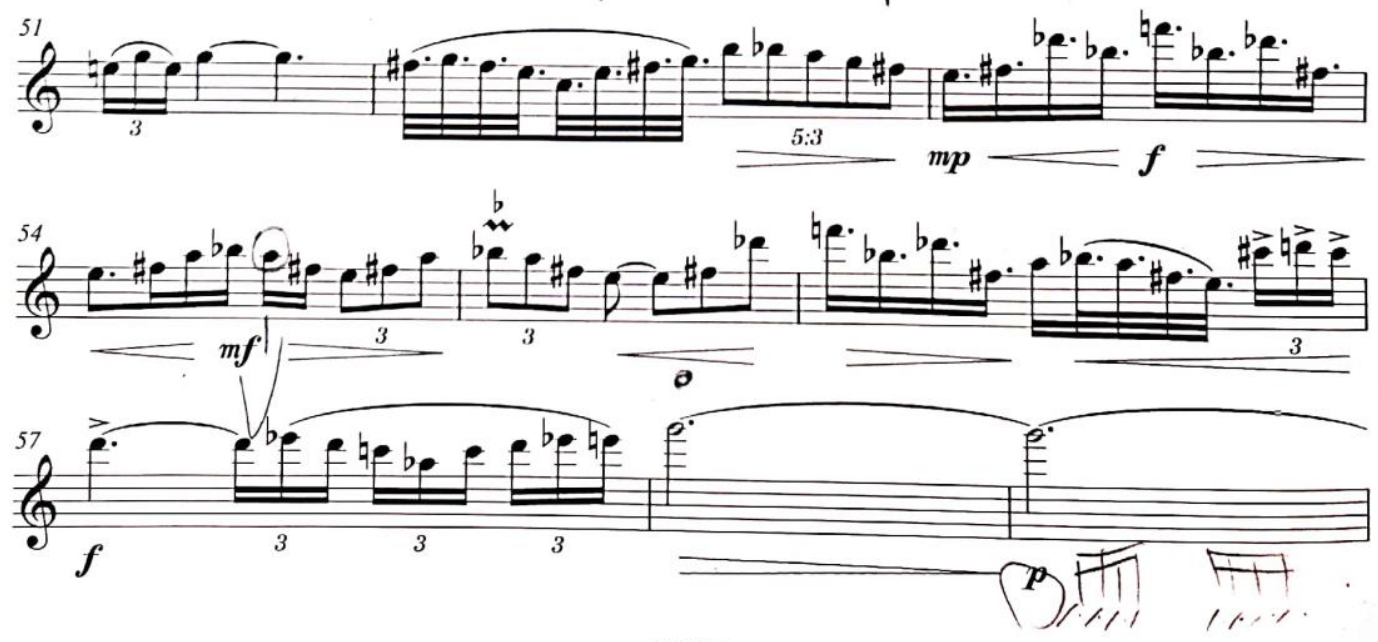

Fonte: LINDBERG, 2013 


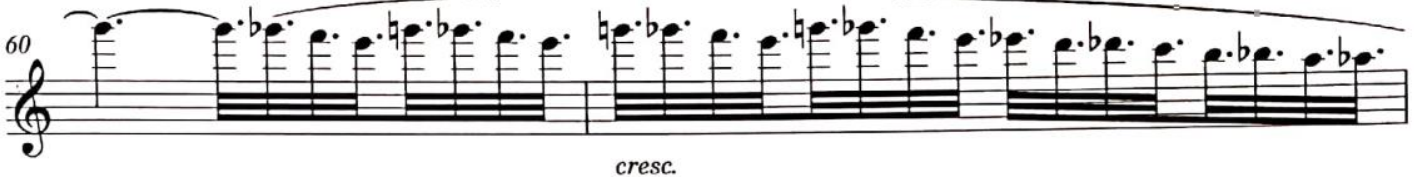

62) be.

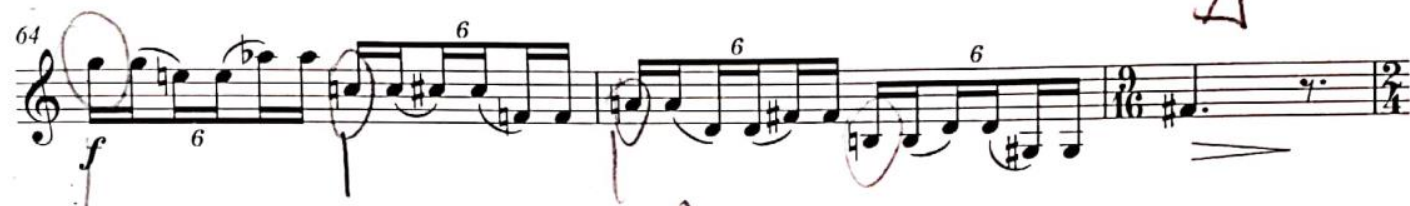

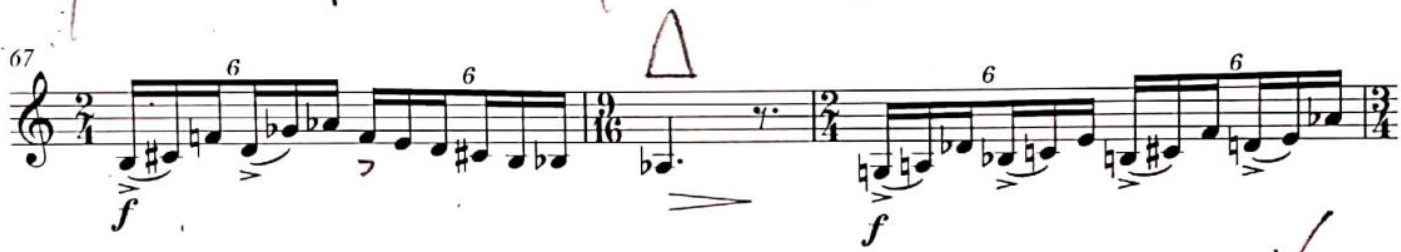
(a)

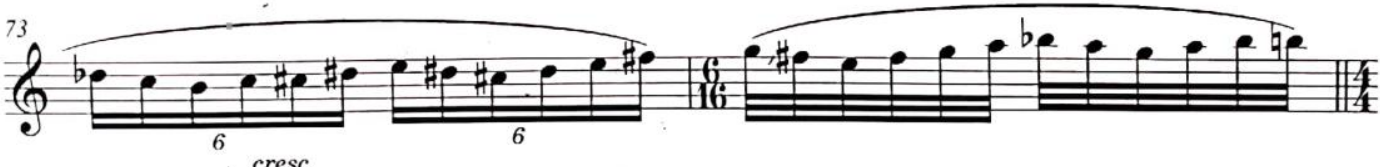

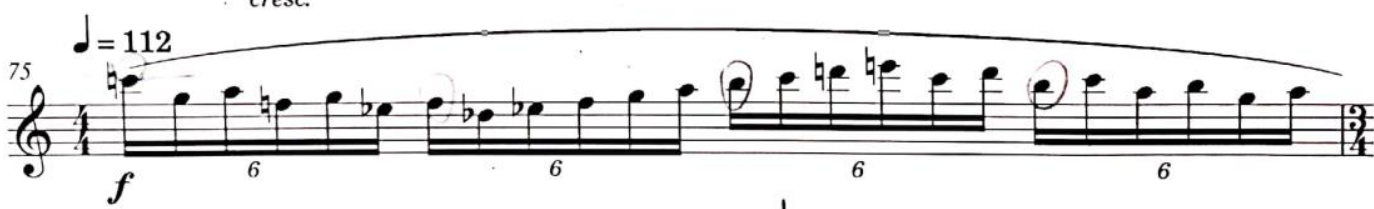

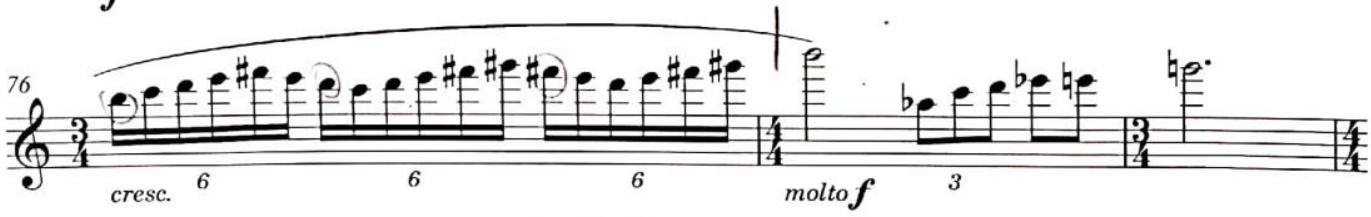

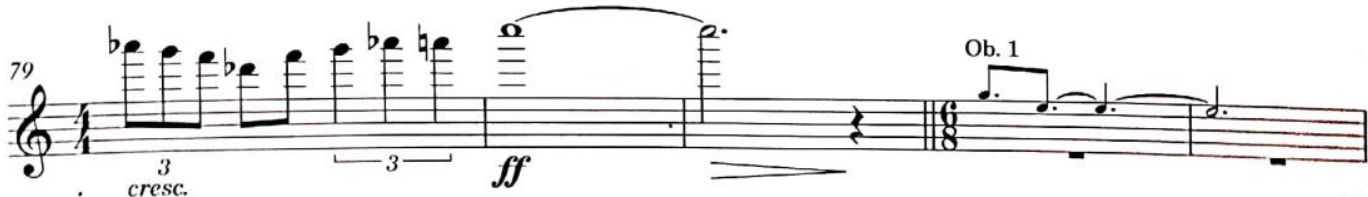
13348 
4
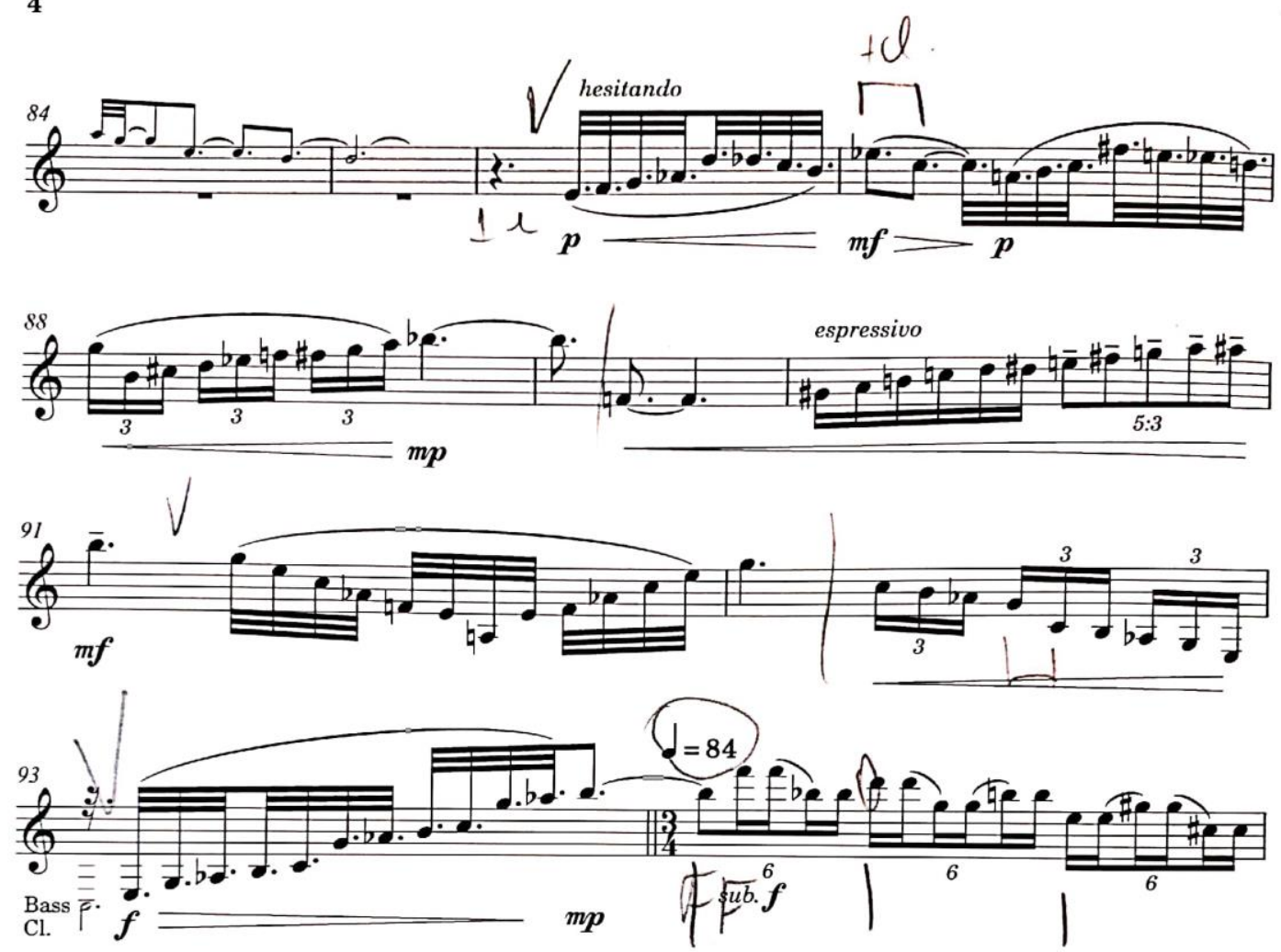

$\frac{25}{{ }_{\text {meno }} \mathrm{f}}$

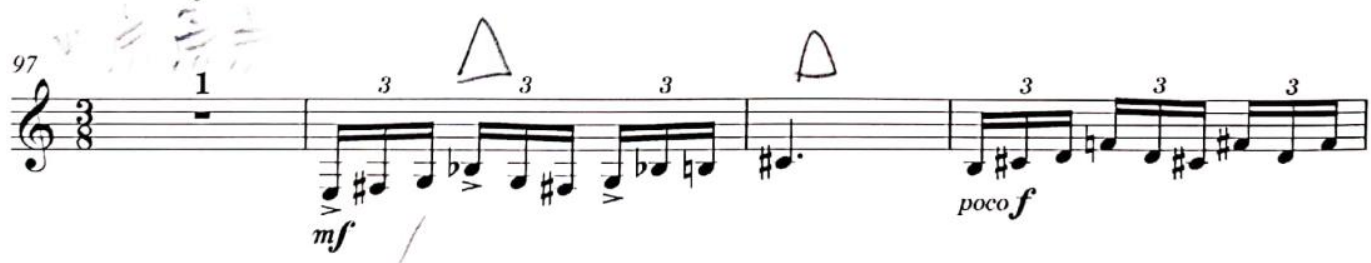

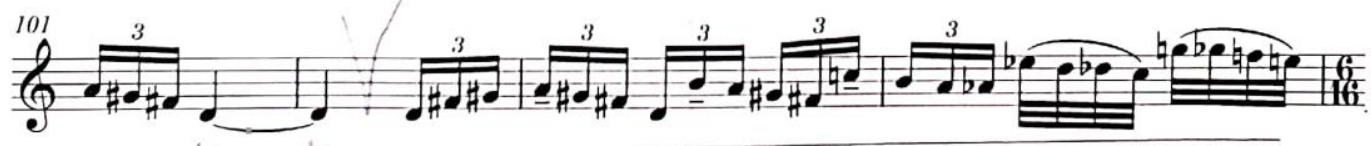
(a) 1605 13348 

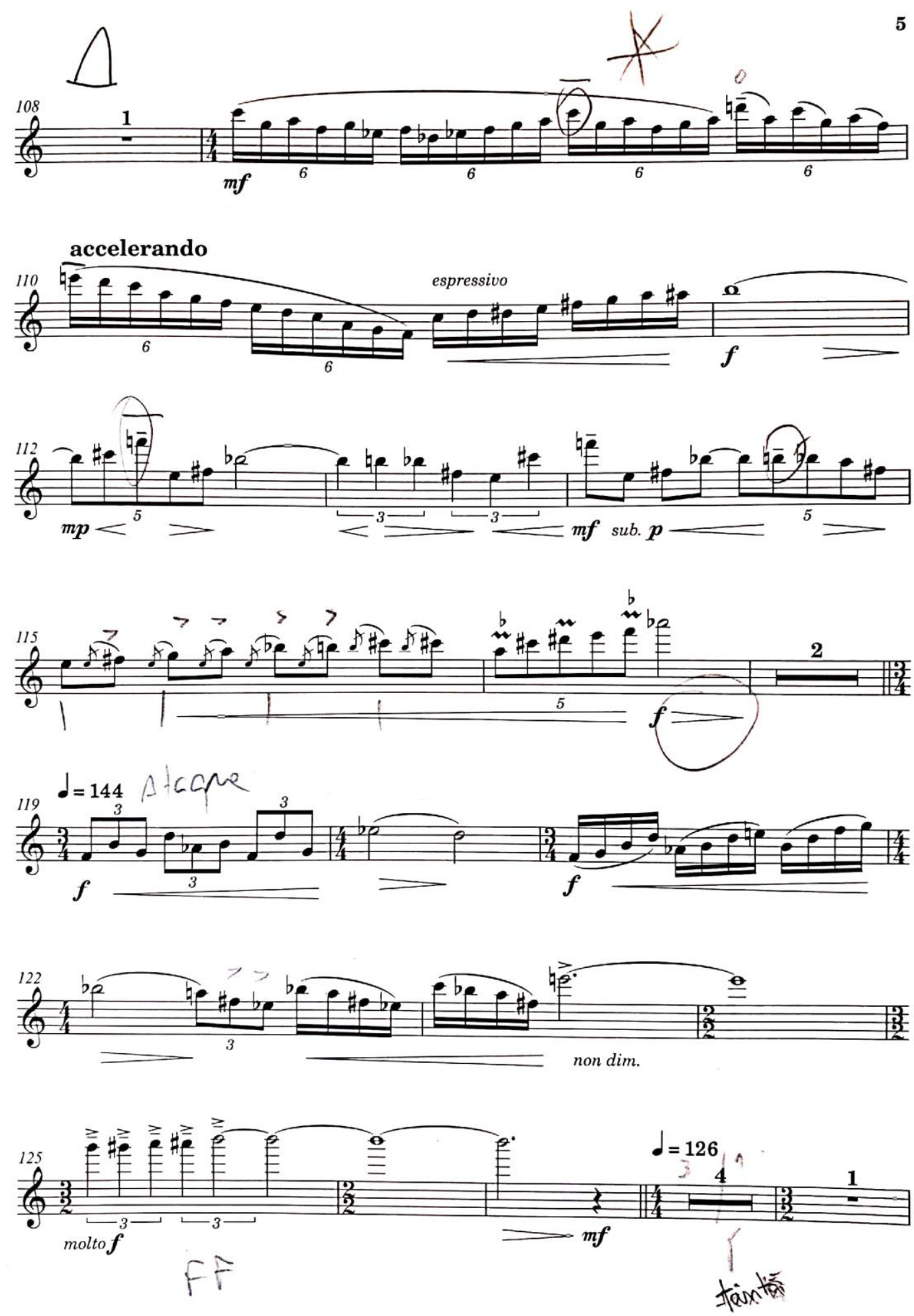

13348

Fonte: LINDBERG, 2013 
6

6 Wunphina Findods

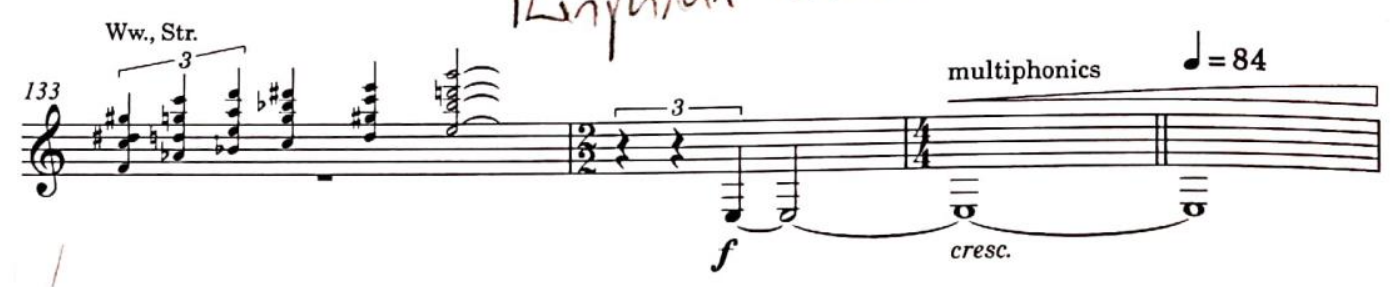

'Horn'-effect

with fingering
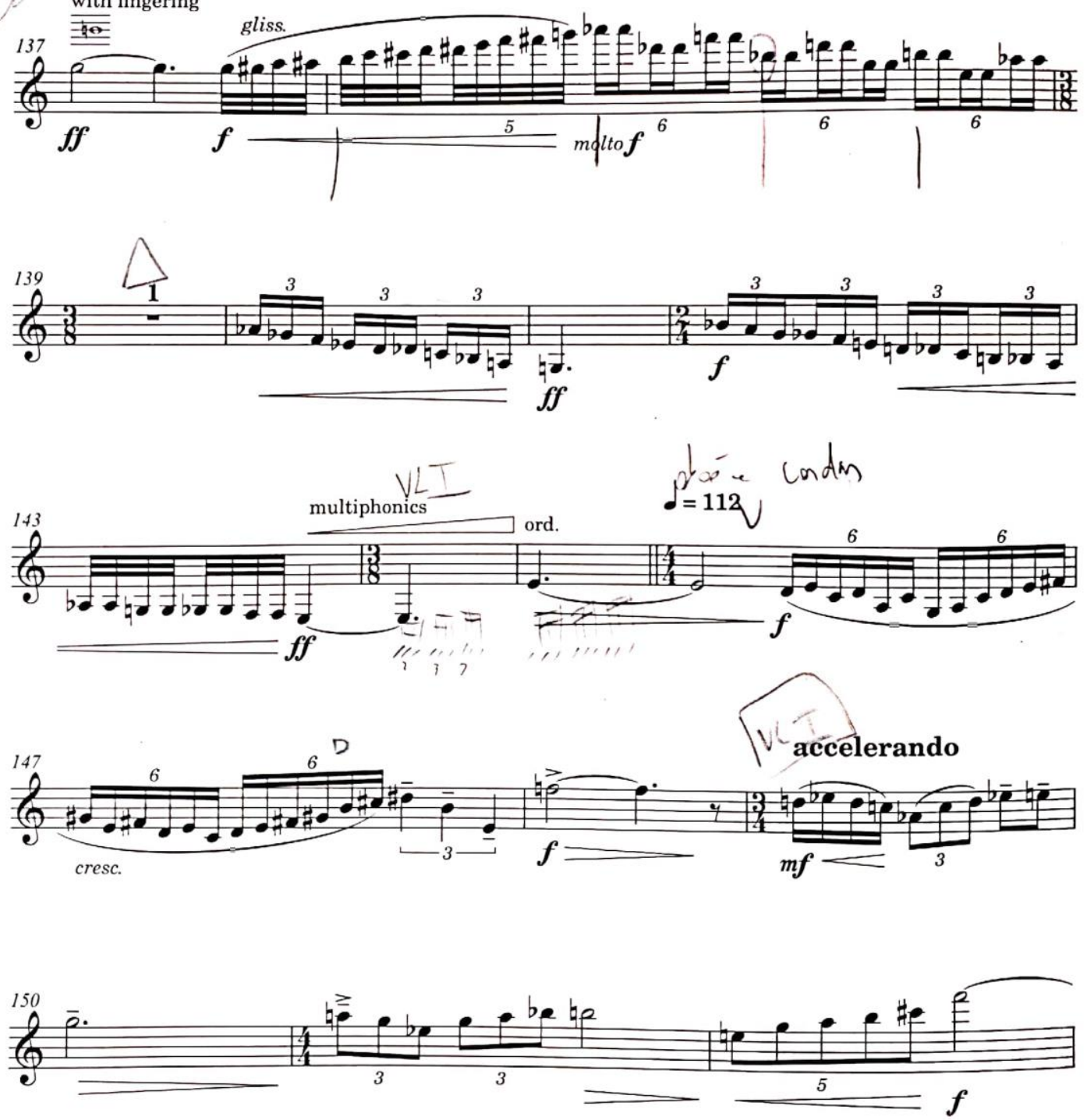

Fonte: LINDBERG, 2013 
77
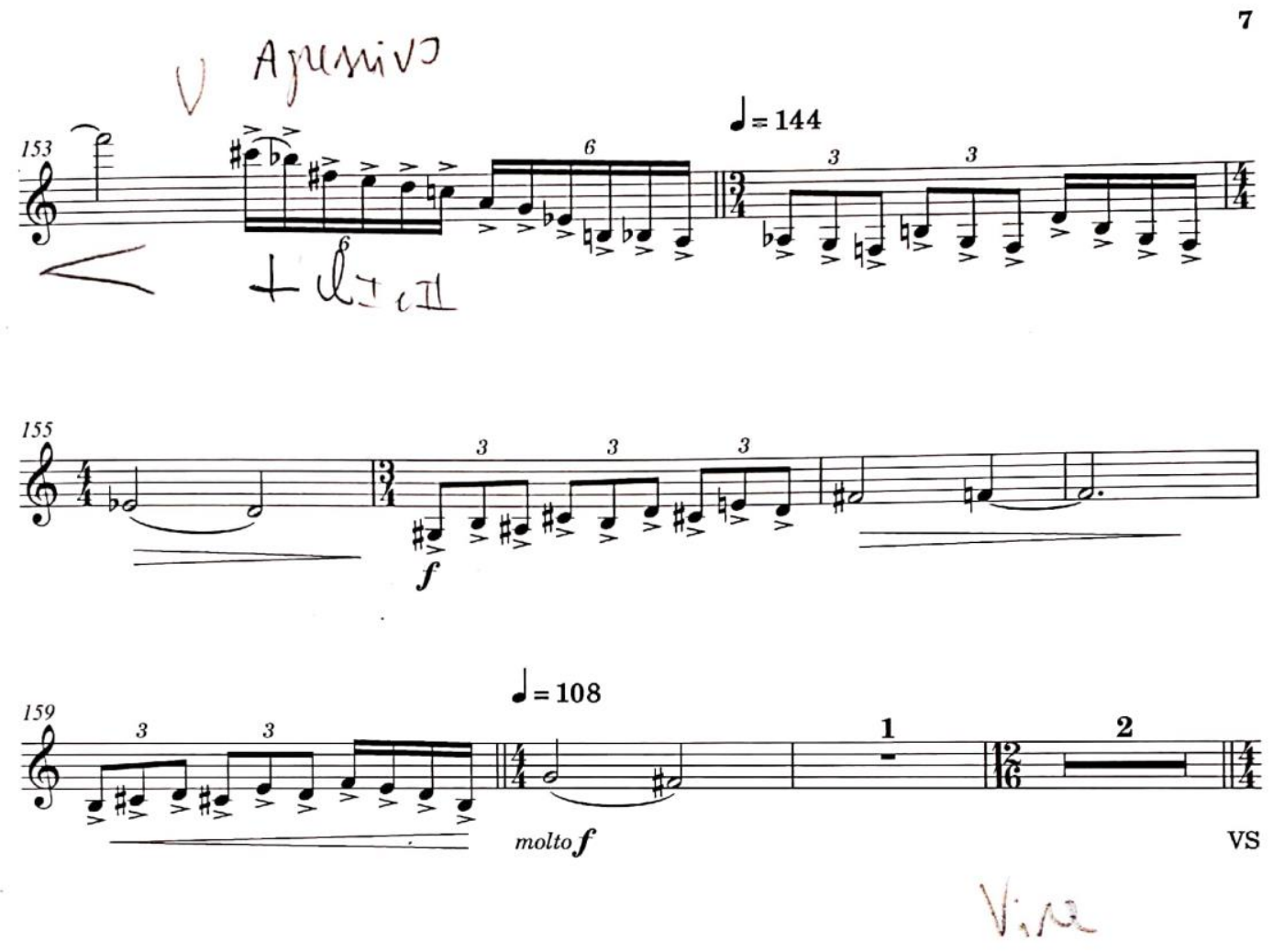

13348

Fonte: LINDBERG, 2013 

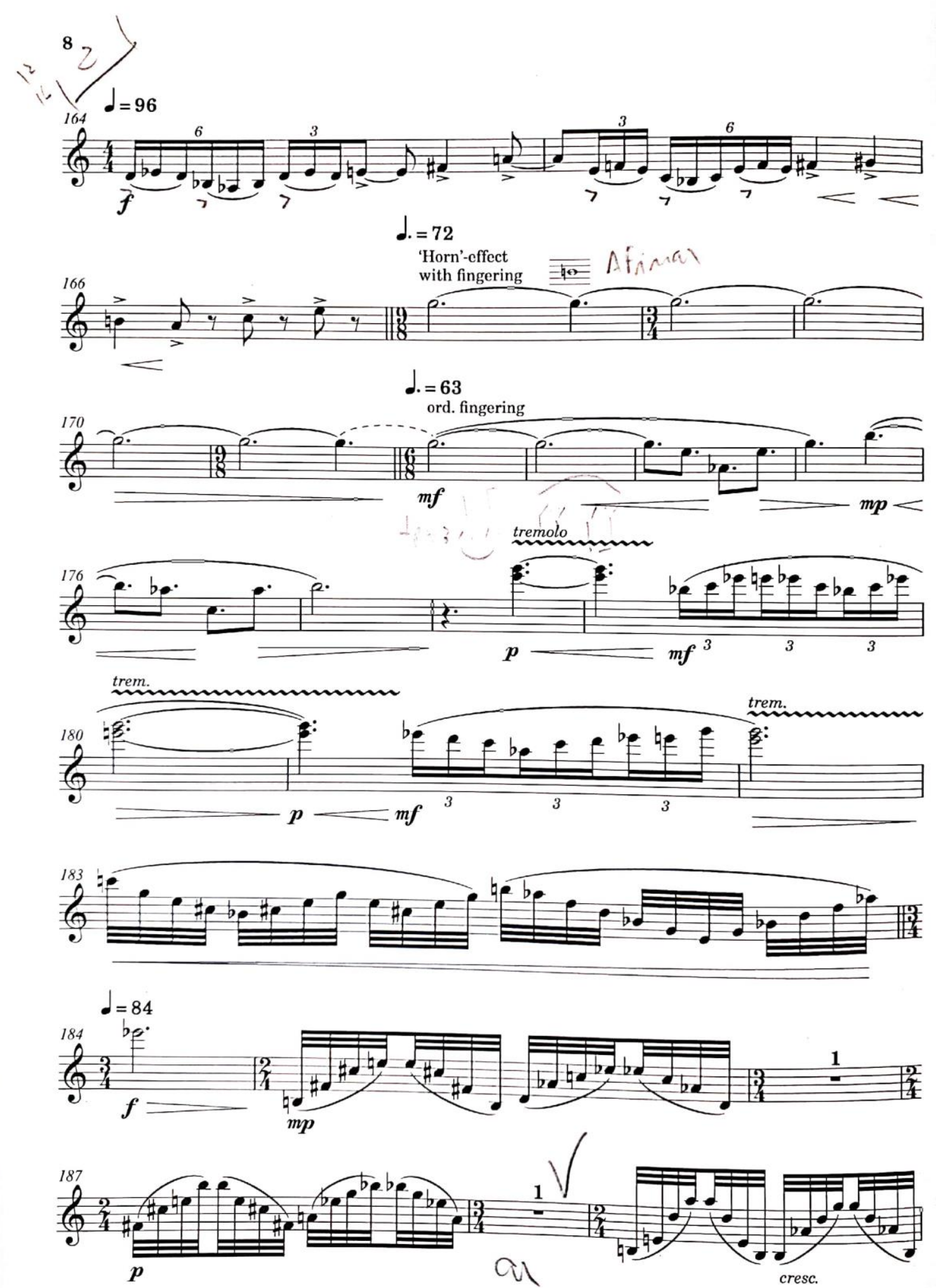

Fonte: LINDBERG, 2013 

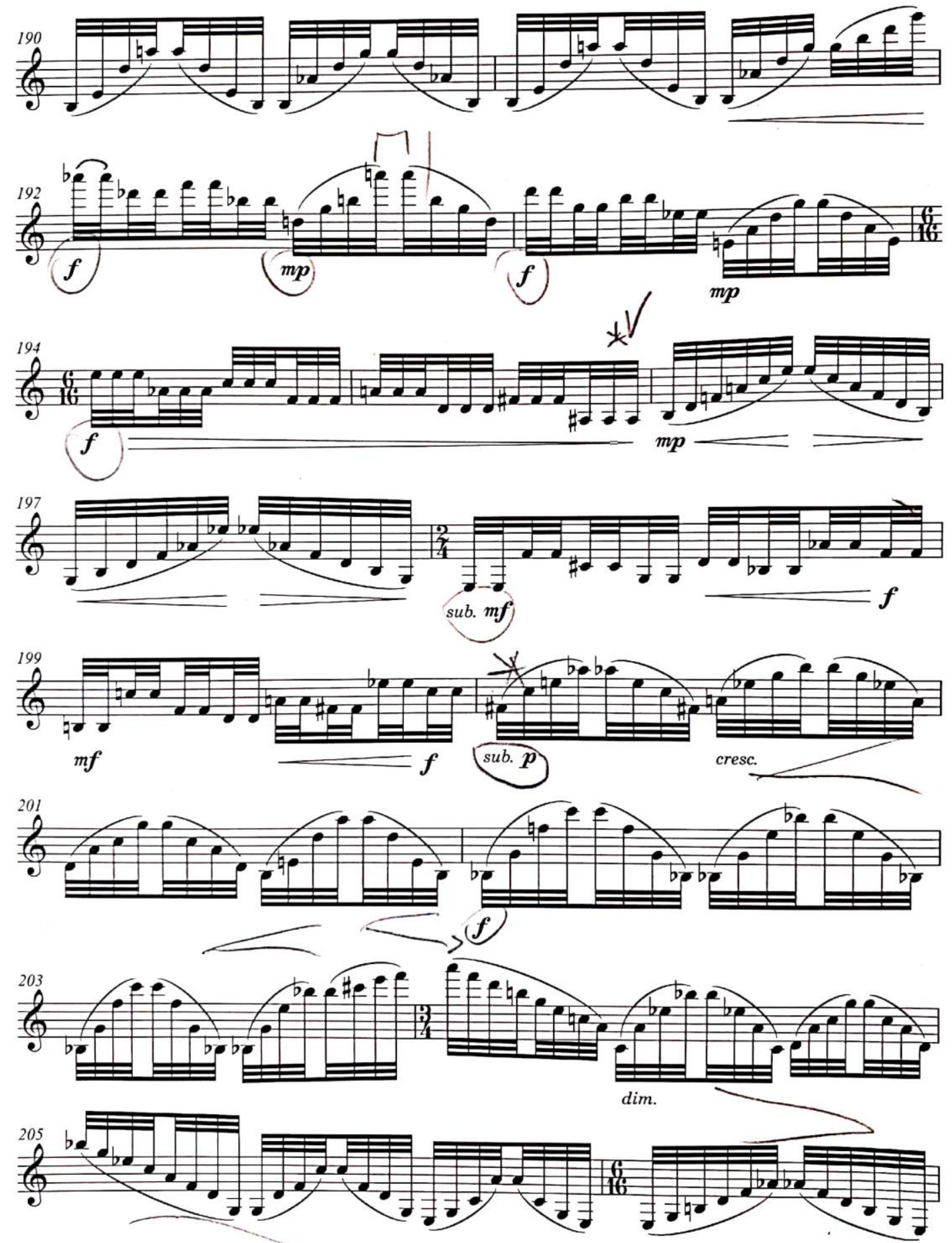

Fonte: LINDBERG, 2013 

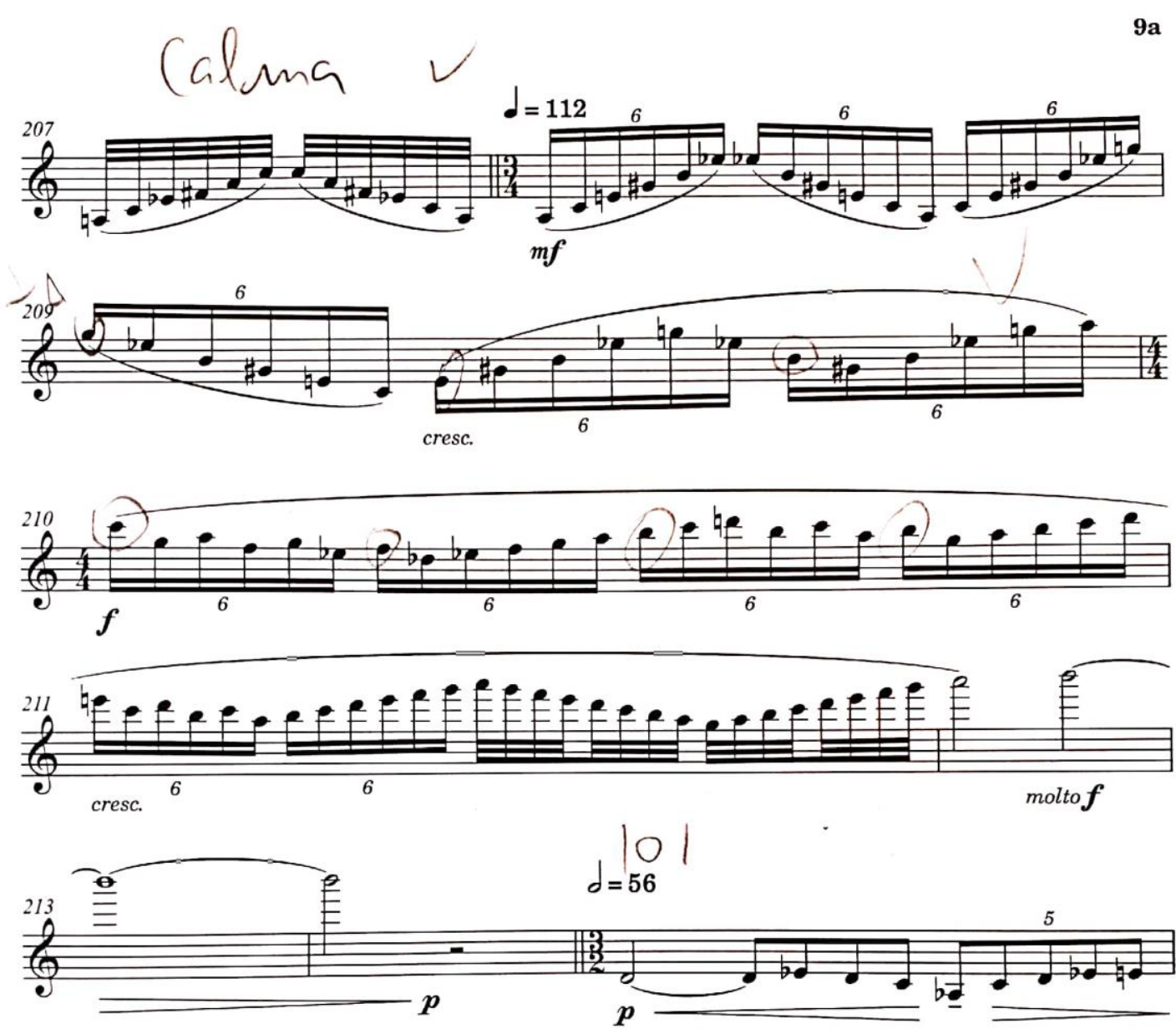

$\left.\right|_{=56}$
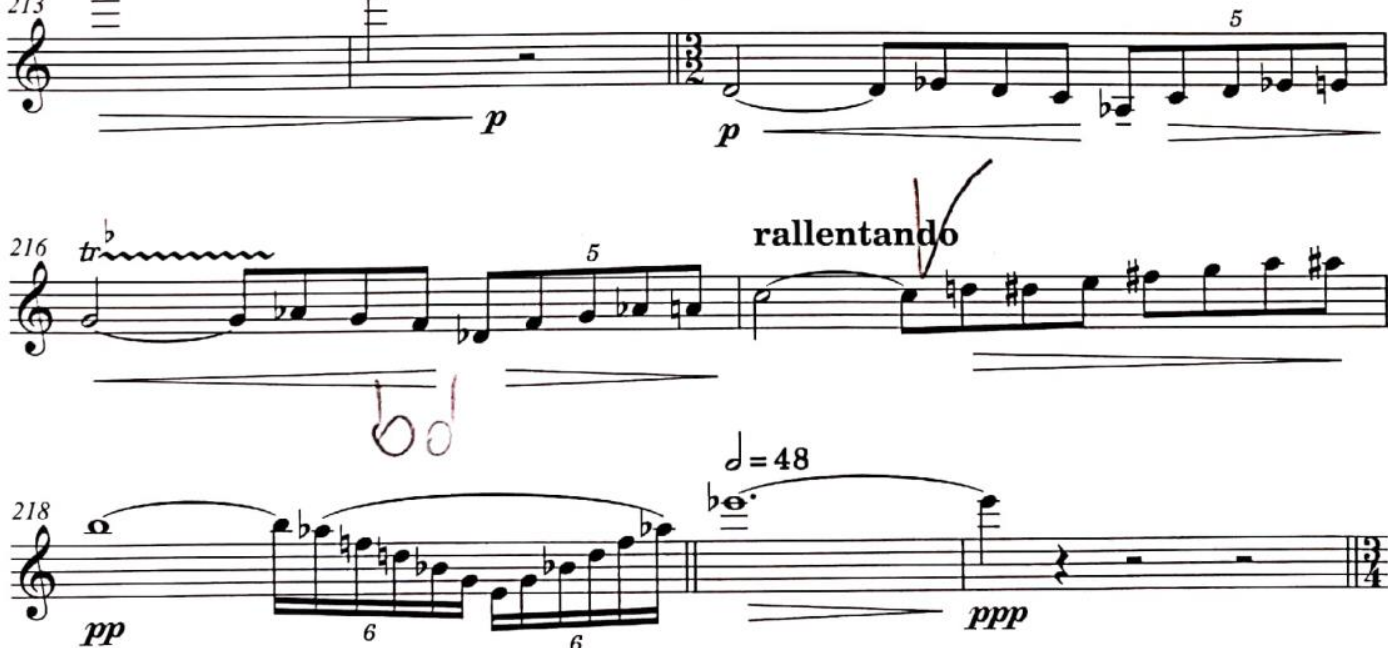

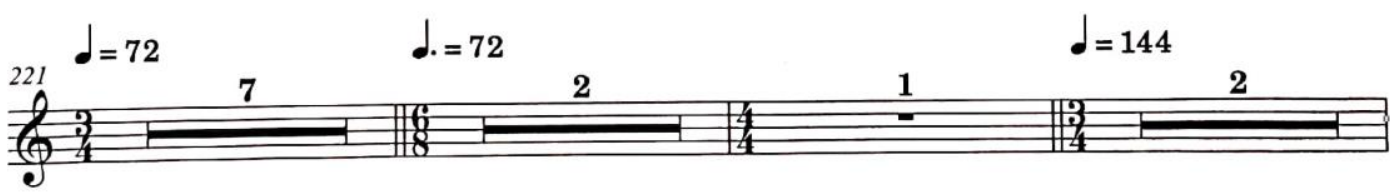



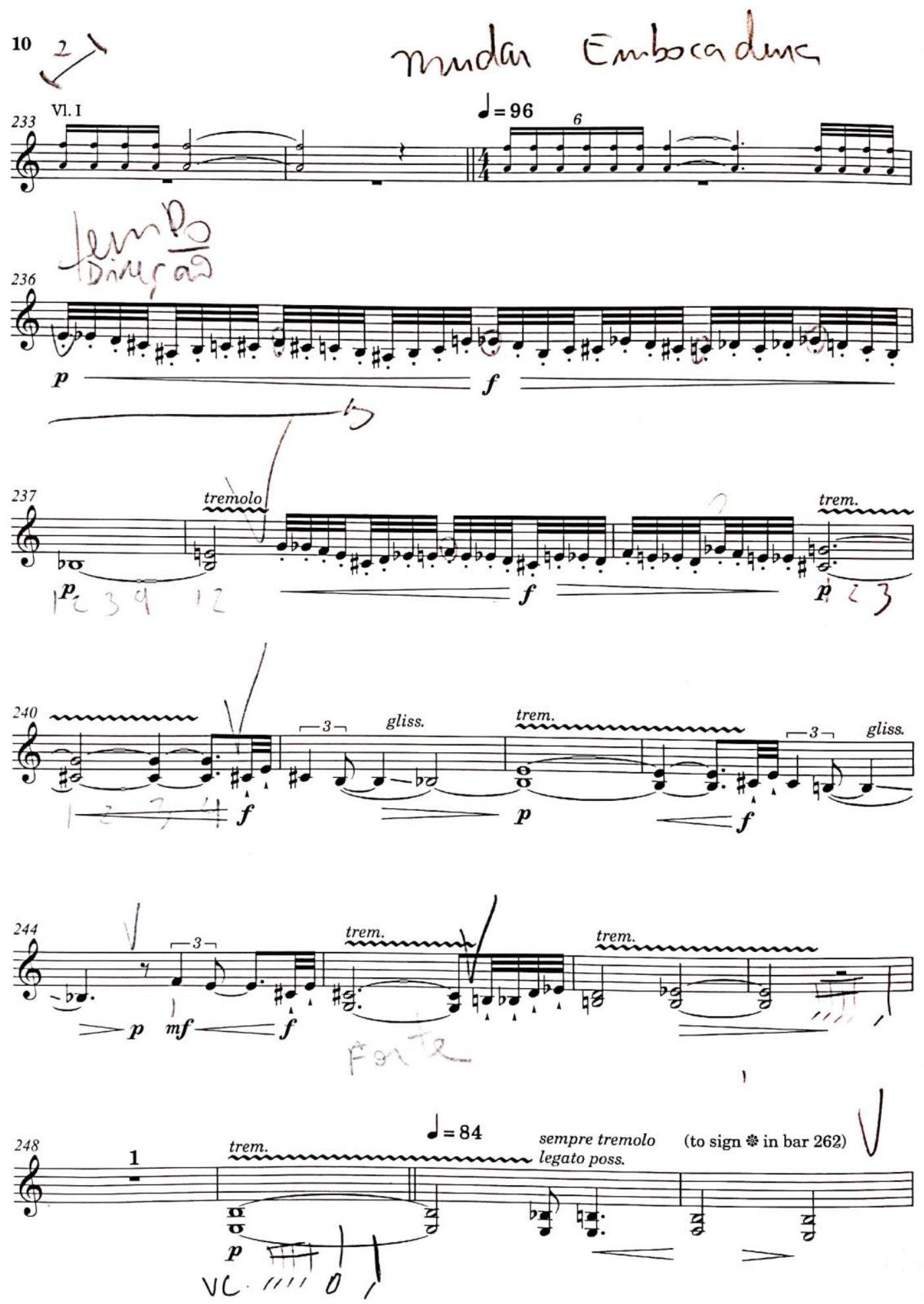

Fonte: LINDBERG, 2013 
trimado Rápido Gesto
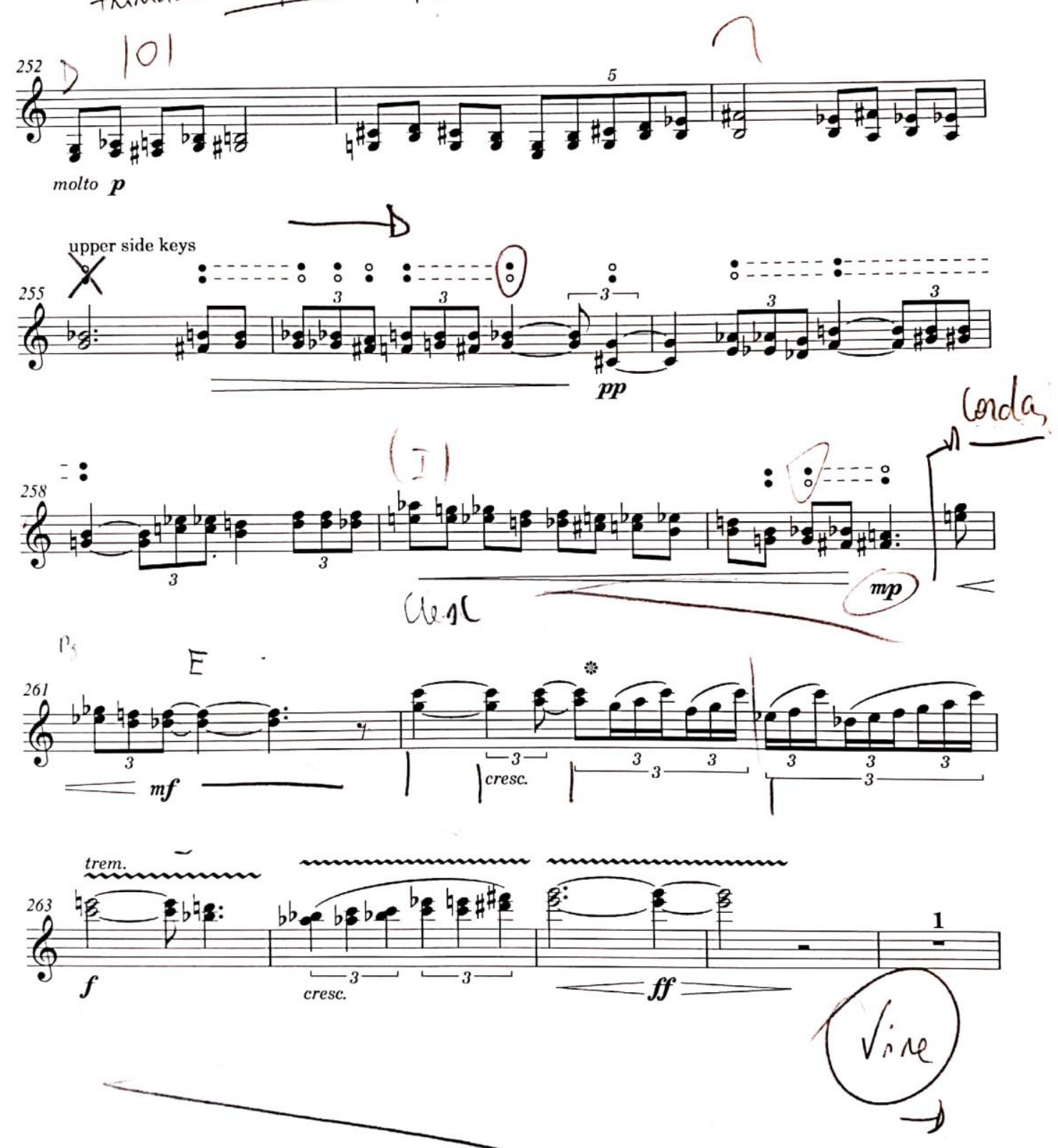

Fonte: LINDBERG, 2013 
(9.2)
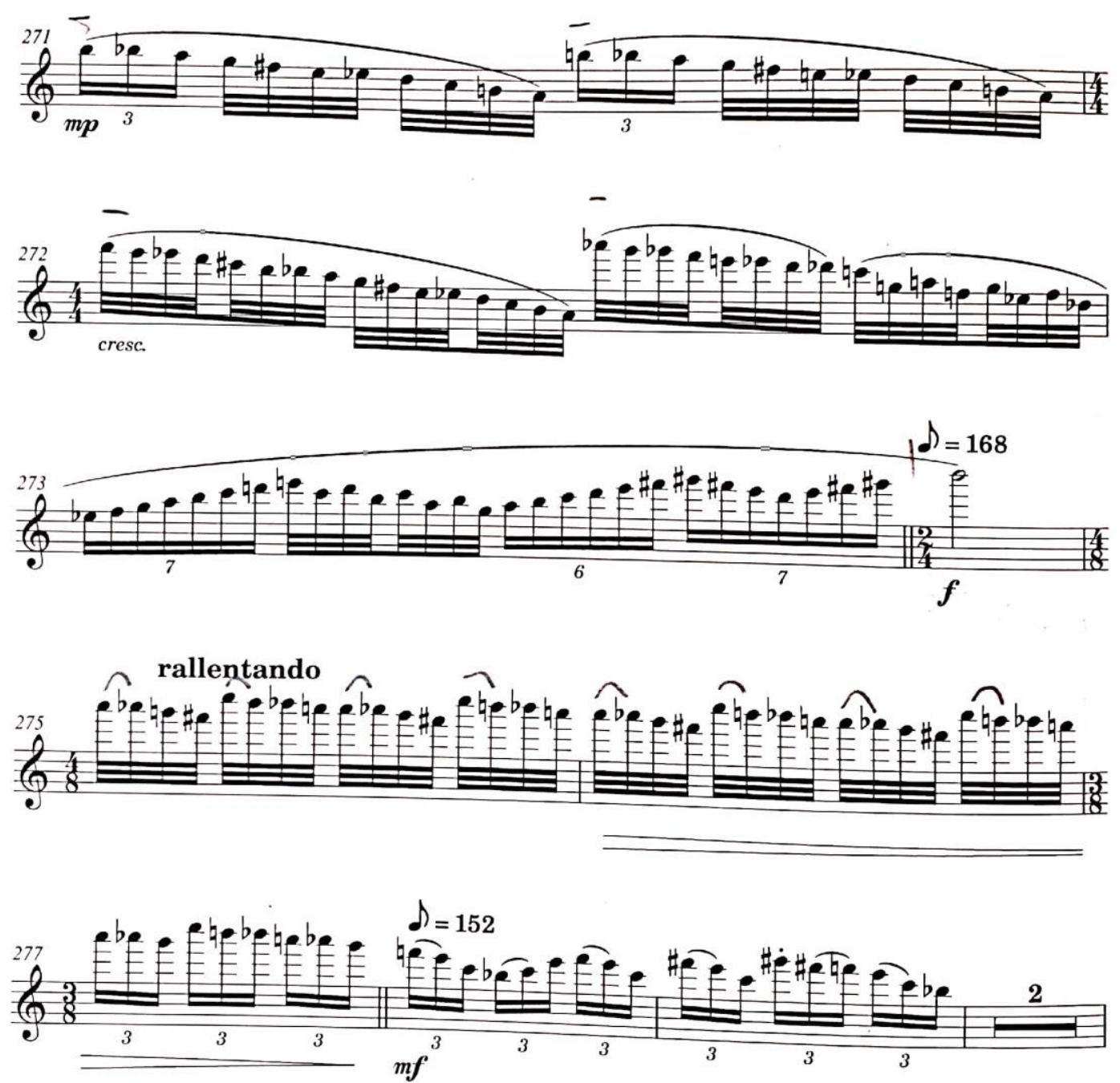

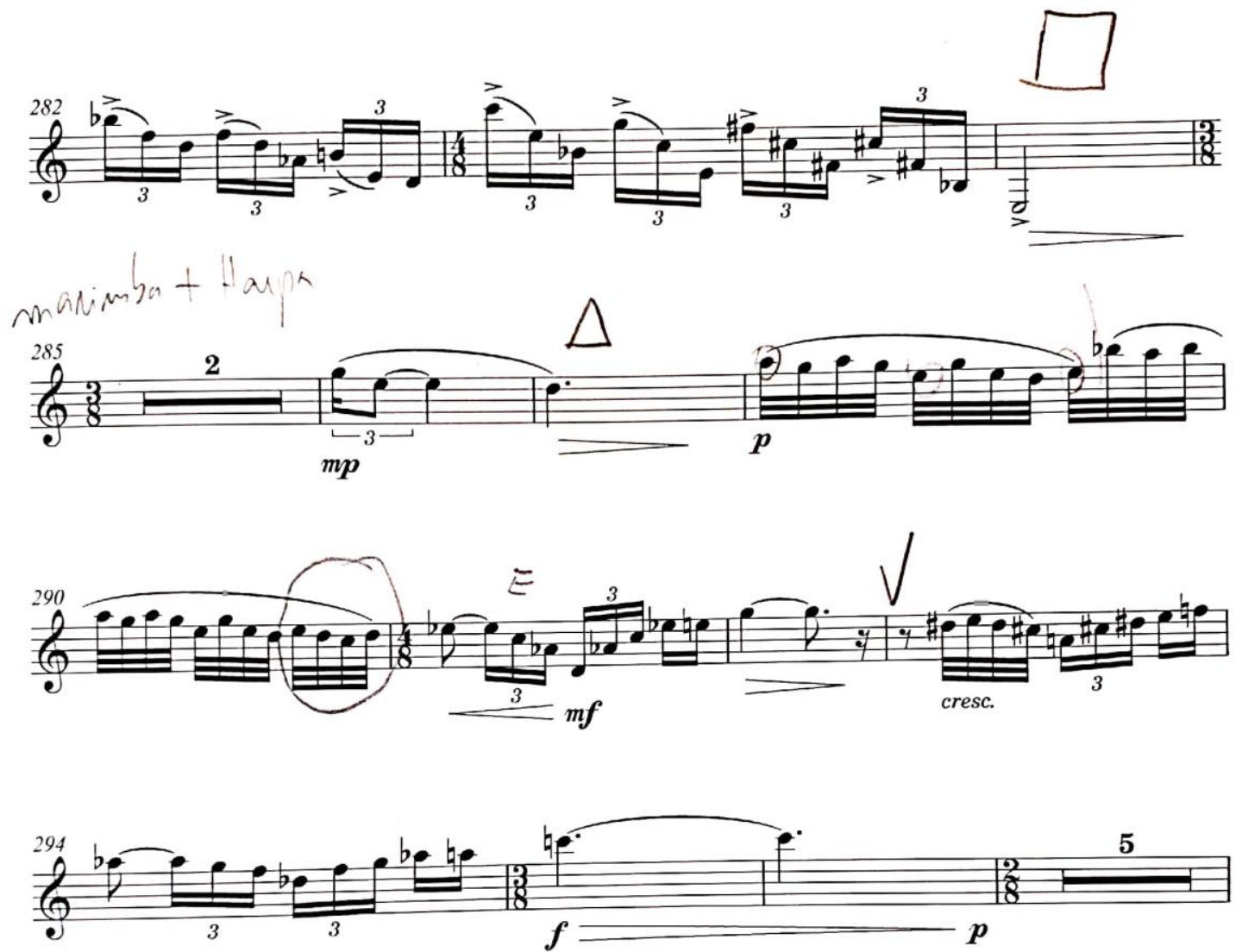

Fonte: LINDBERG, 2013 
14

3 Vl, Vla (pizz.)

rallentando

Q

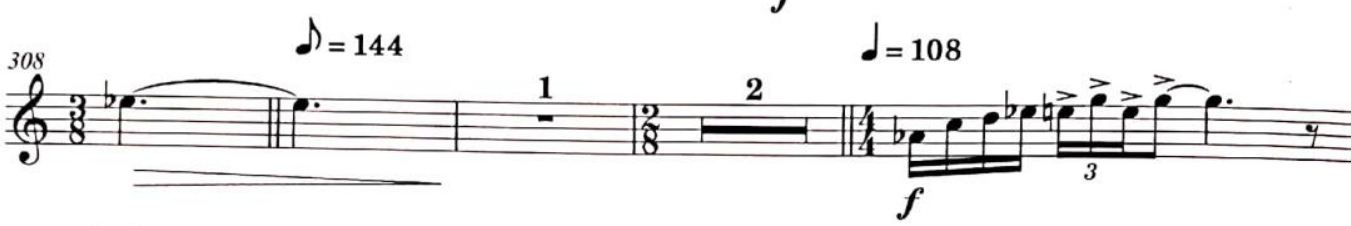

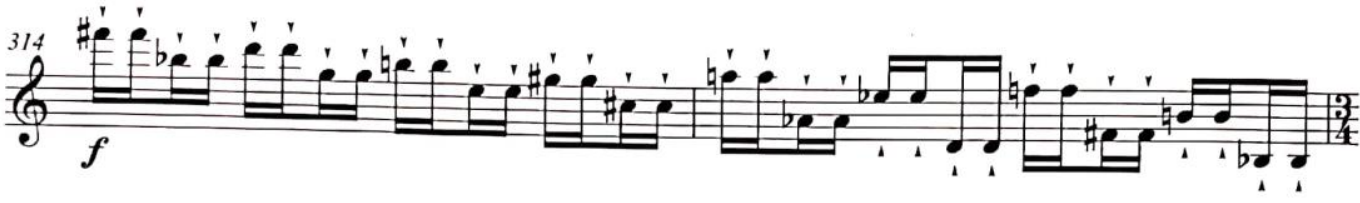
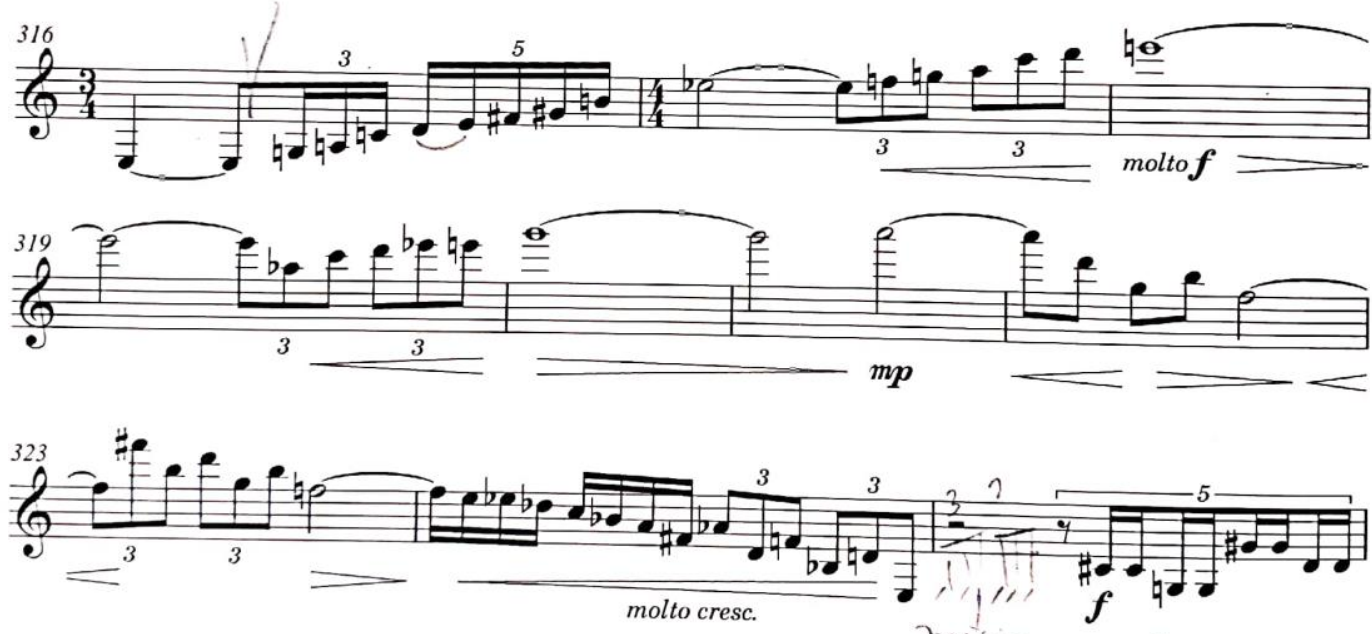

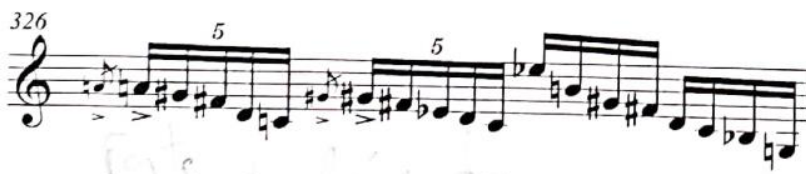

330 d $=128$

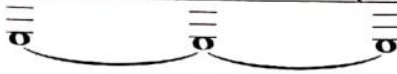

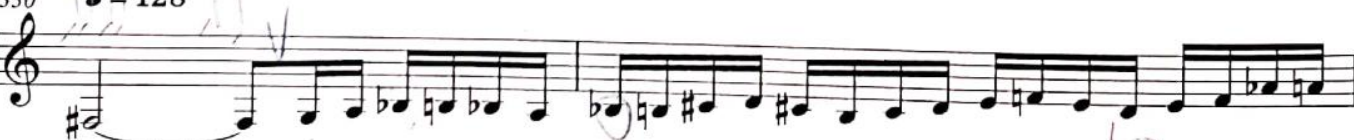
$1 \frac{1}{1} \boldsymbol{f}$
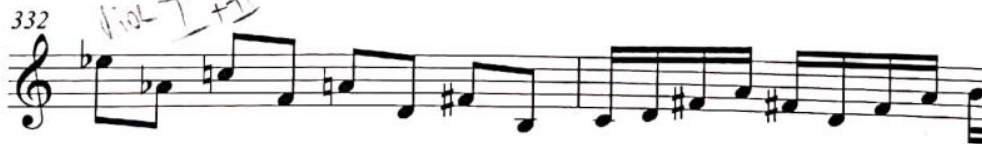

13348

1

Fonte: LINDBERG, 2013 

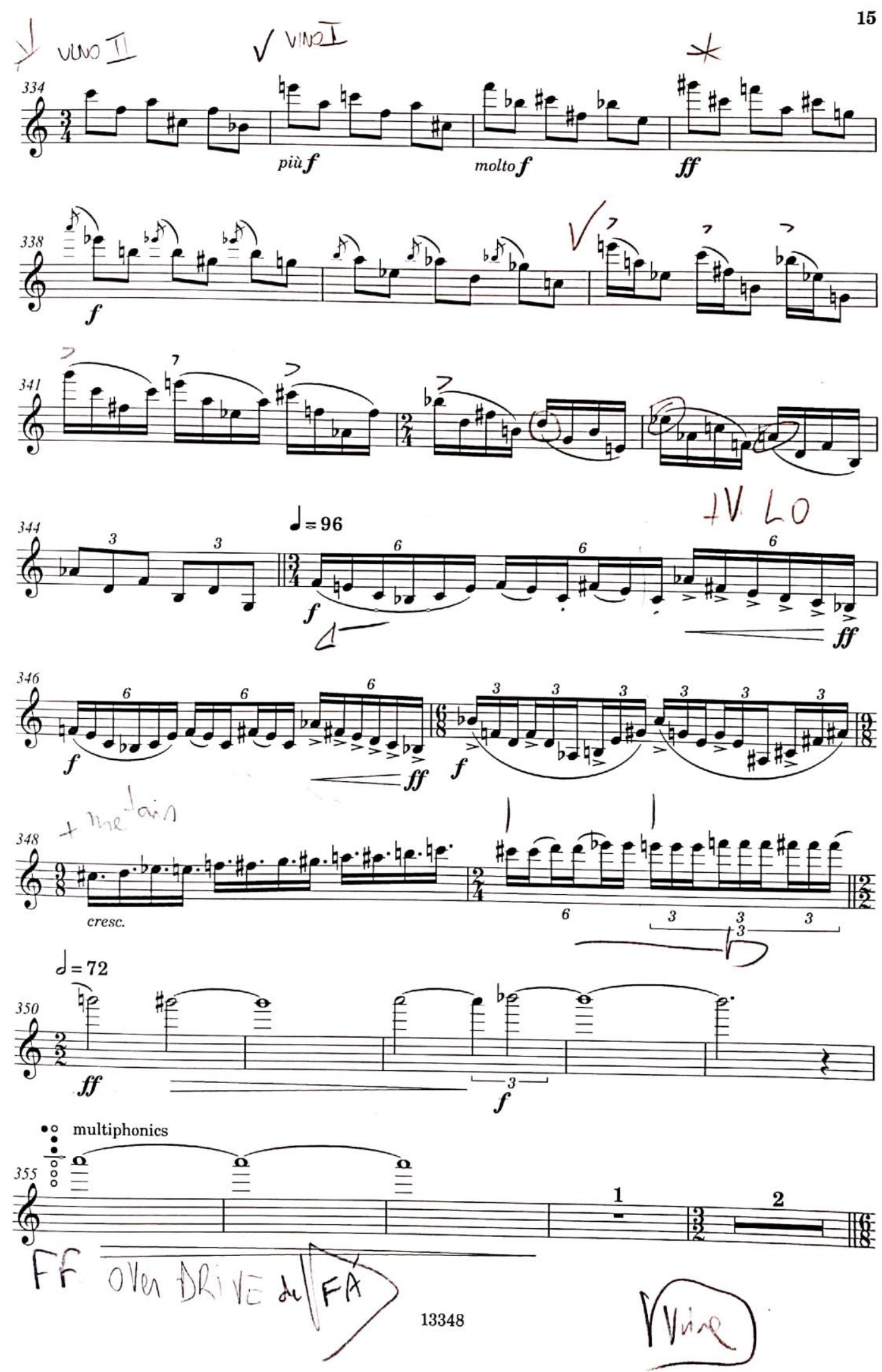

Fonte: LINDBERG, 2013 


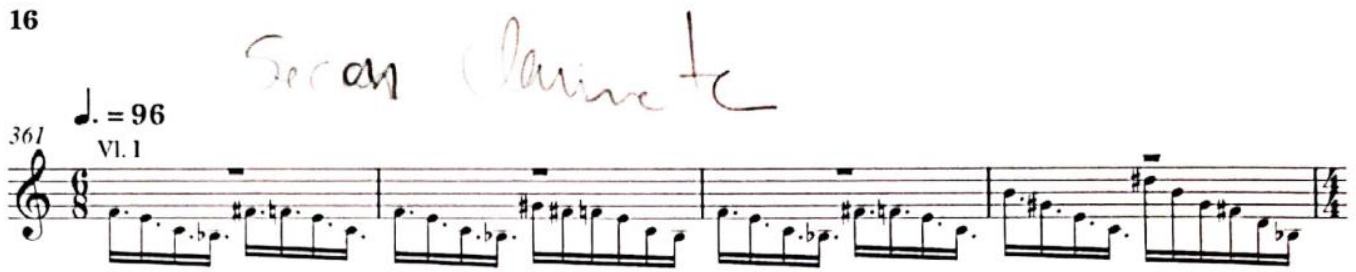
(a) 144)
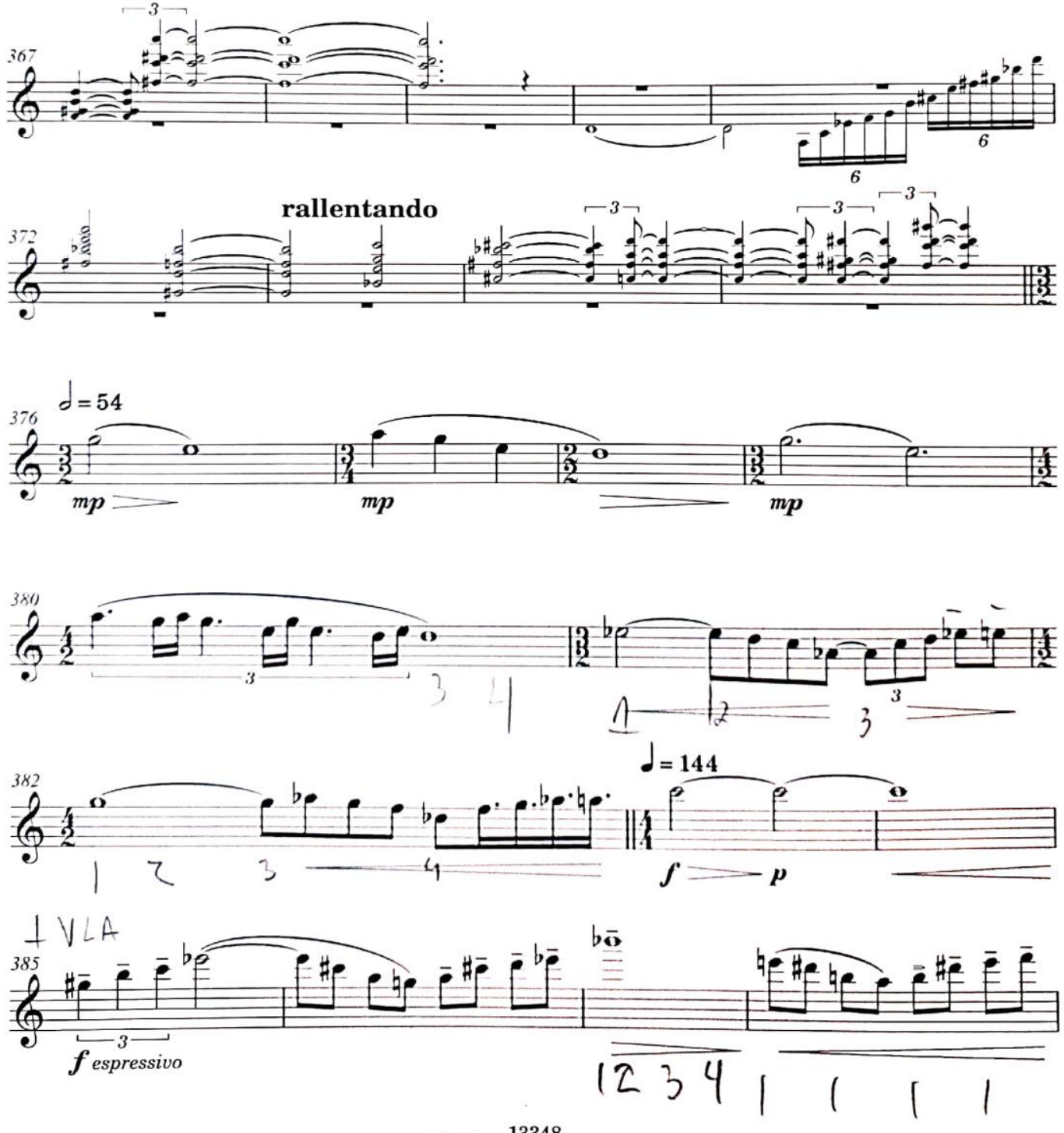

Fonte: LINDBERG, 2013 

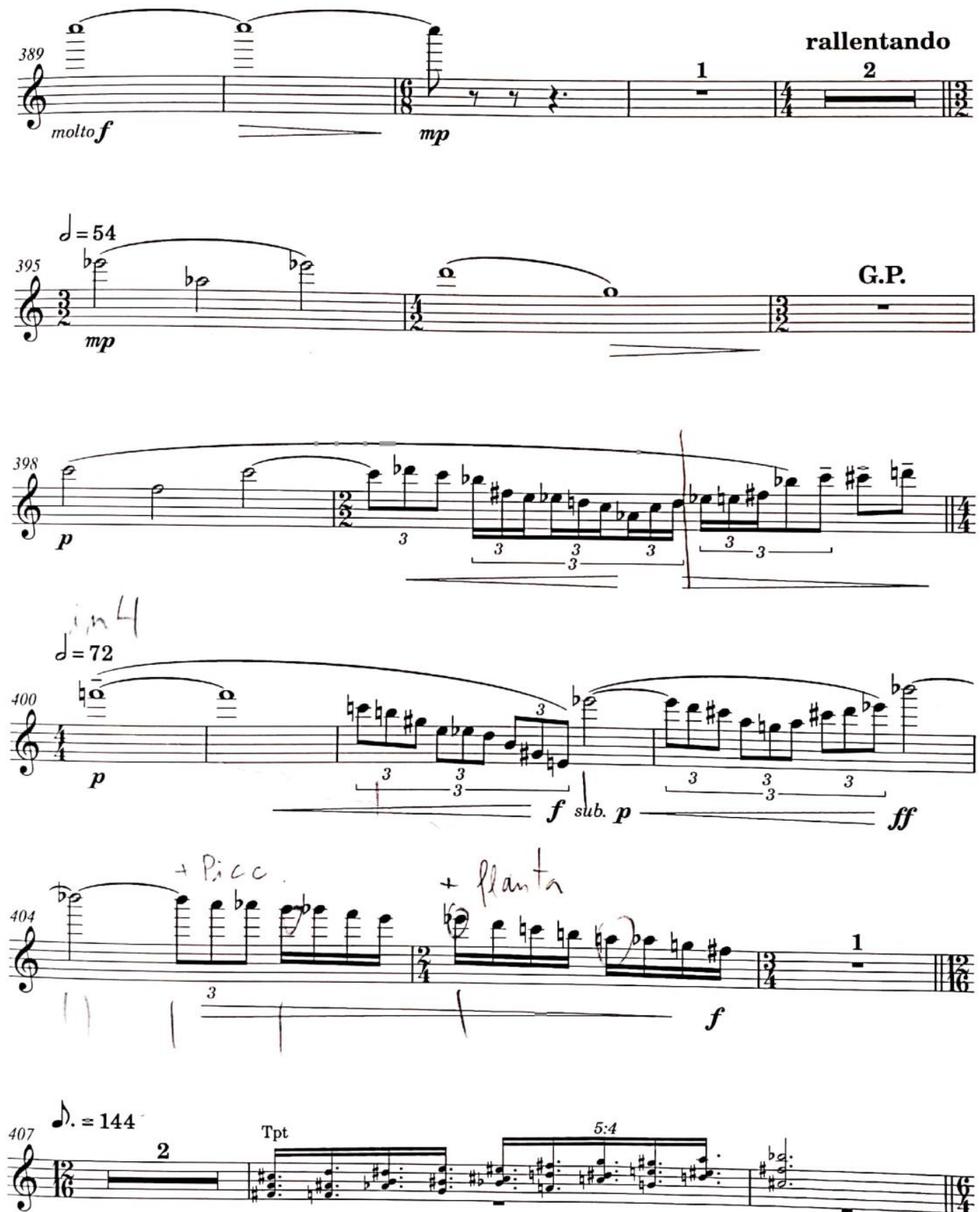

vs 
18
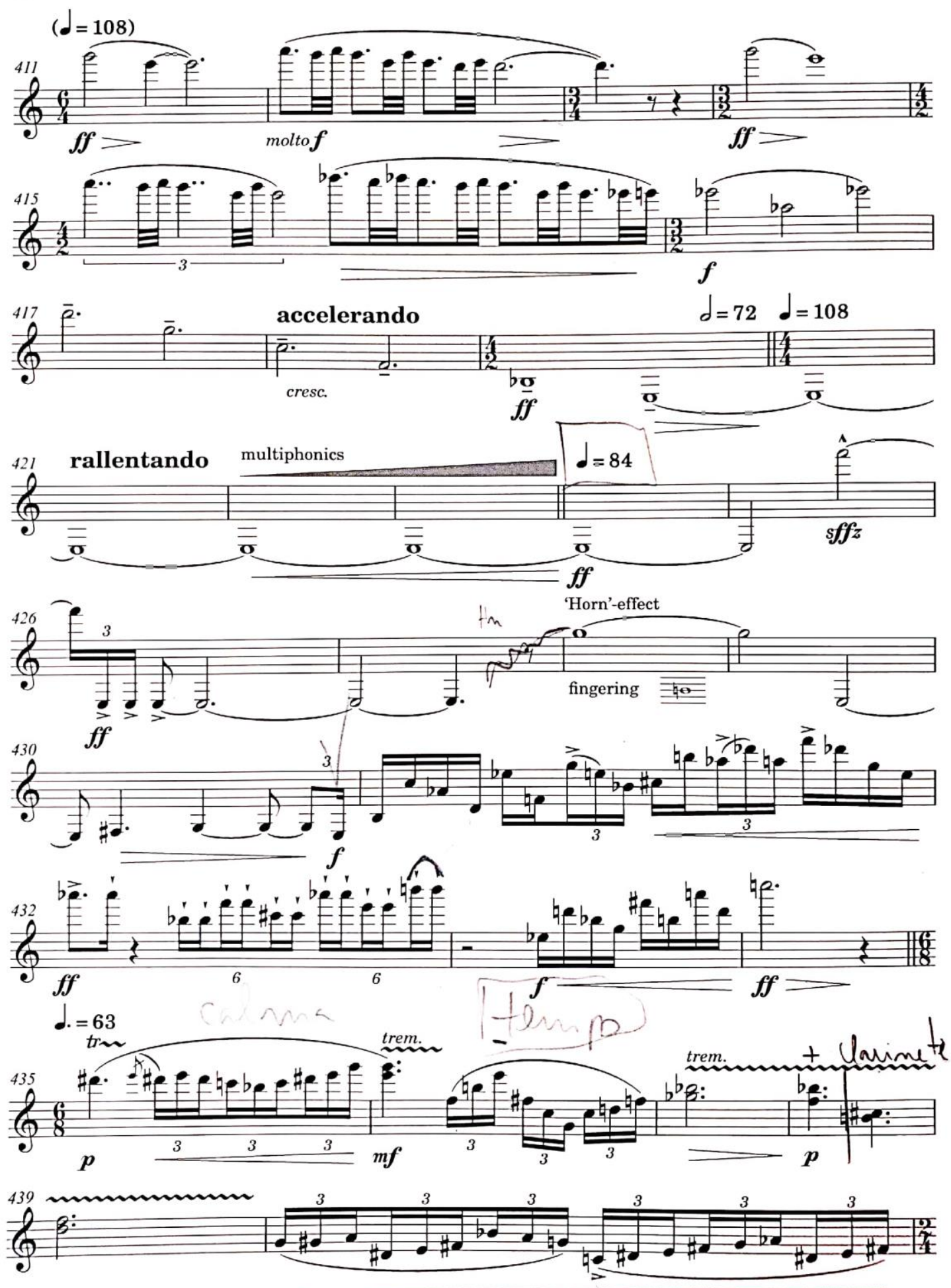

13348

Fonte: LINDBERG, 2013 

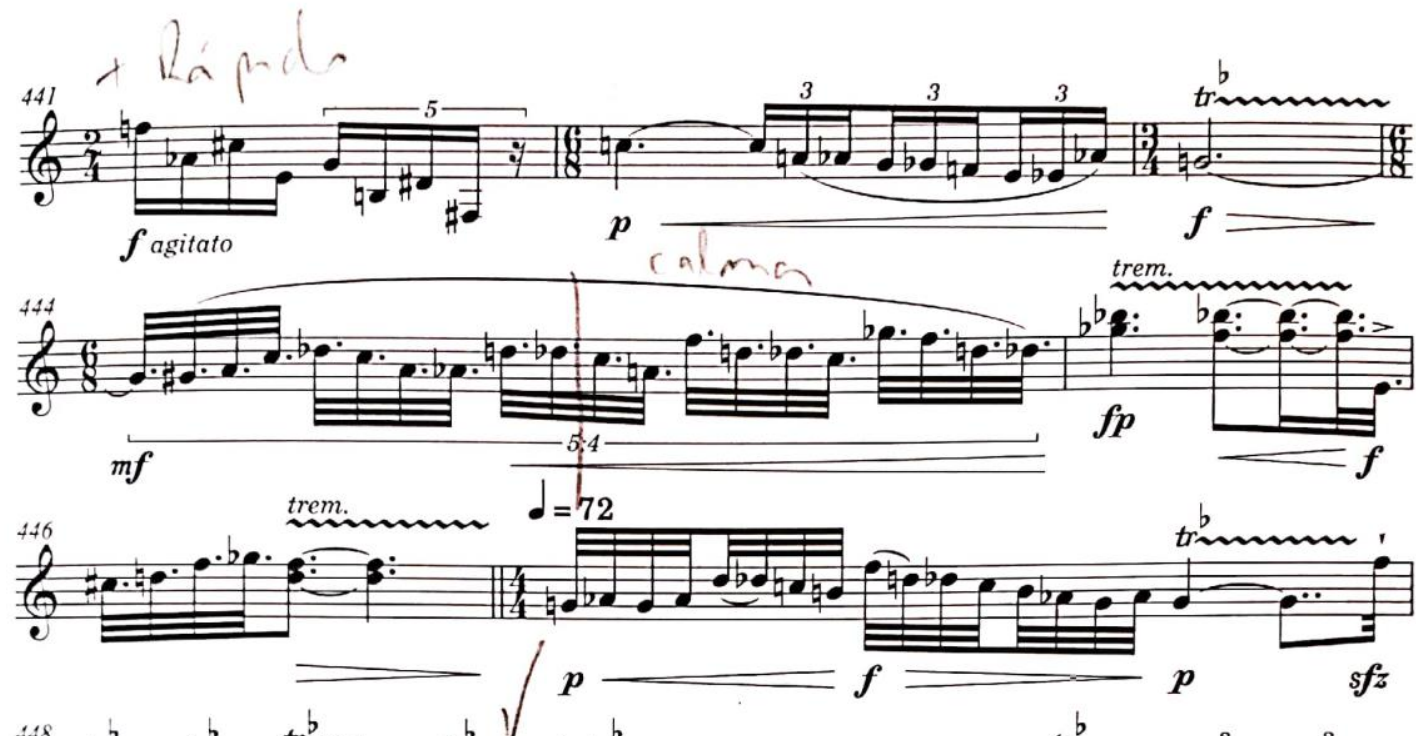

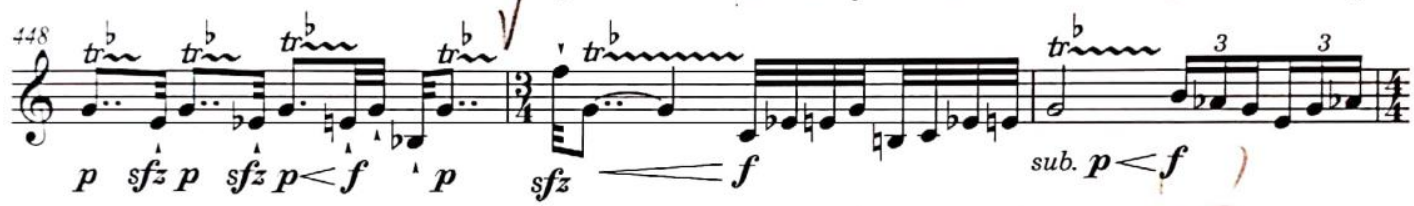
pp Prp

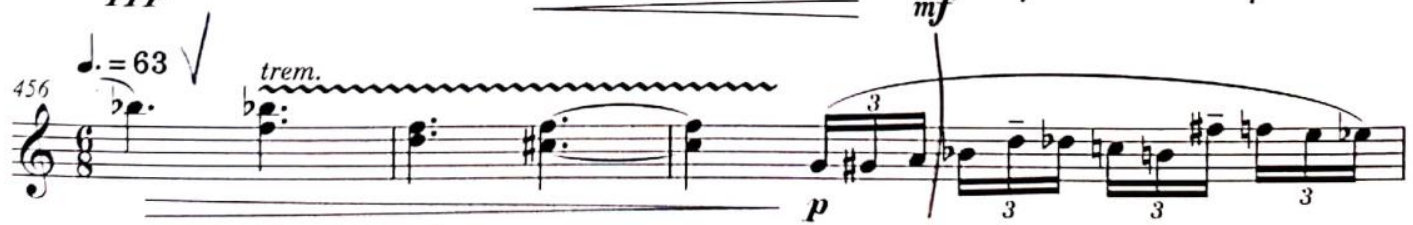
(a) $2_{1}^{2_{3}^{3}}$ 

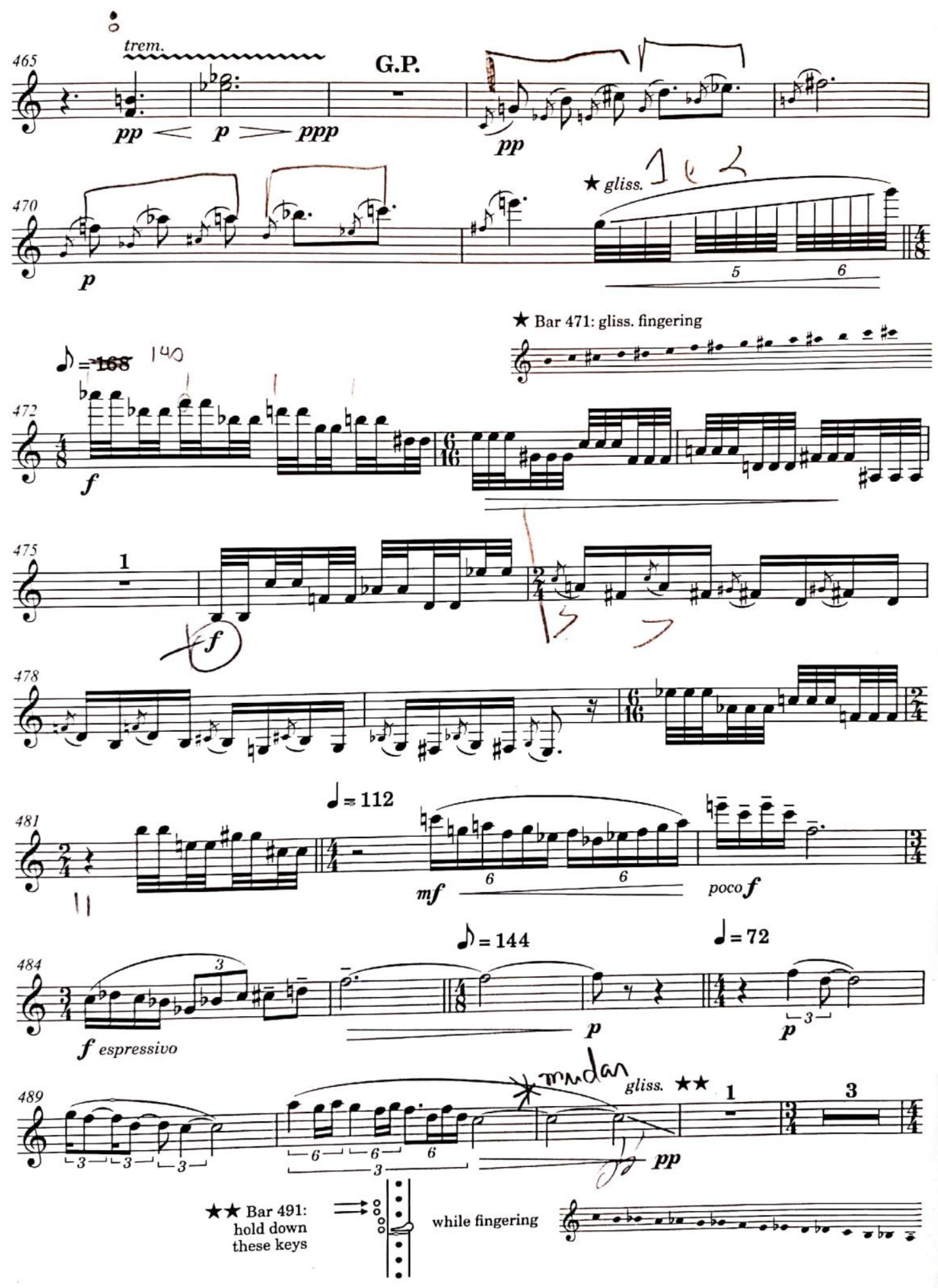

13348

Fonte: LINDBERG, 2013 
20
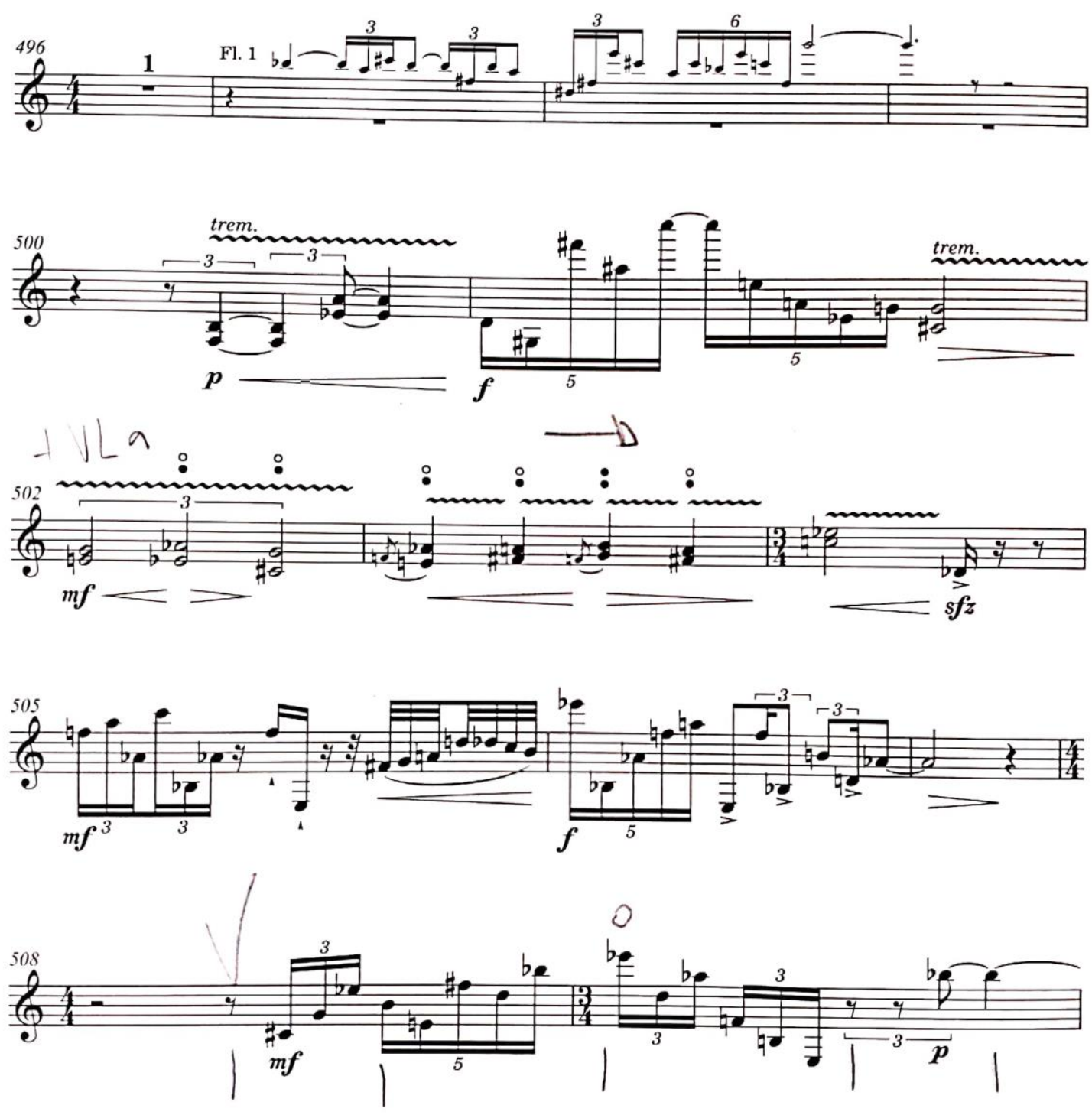

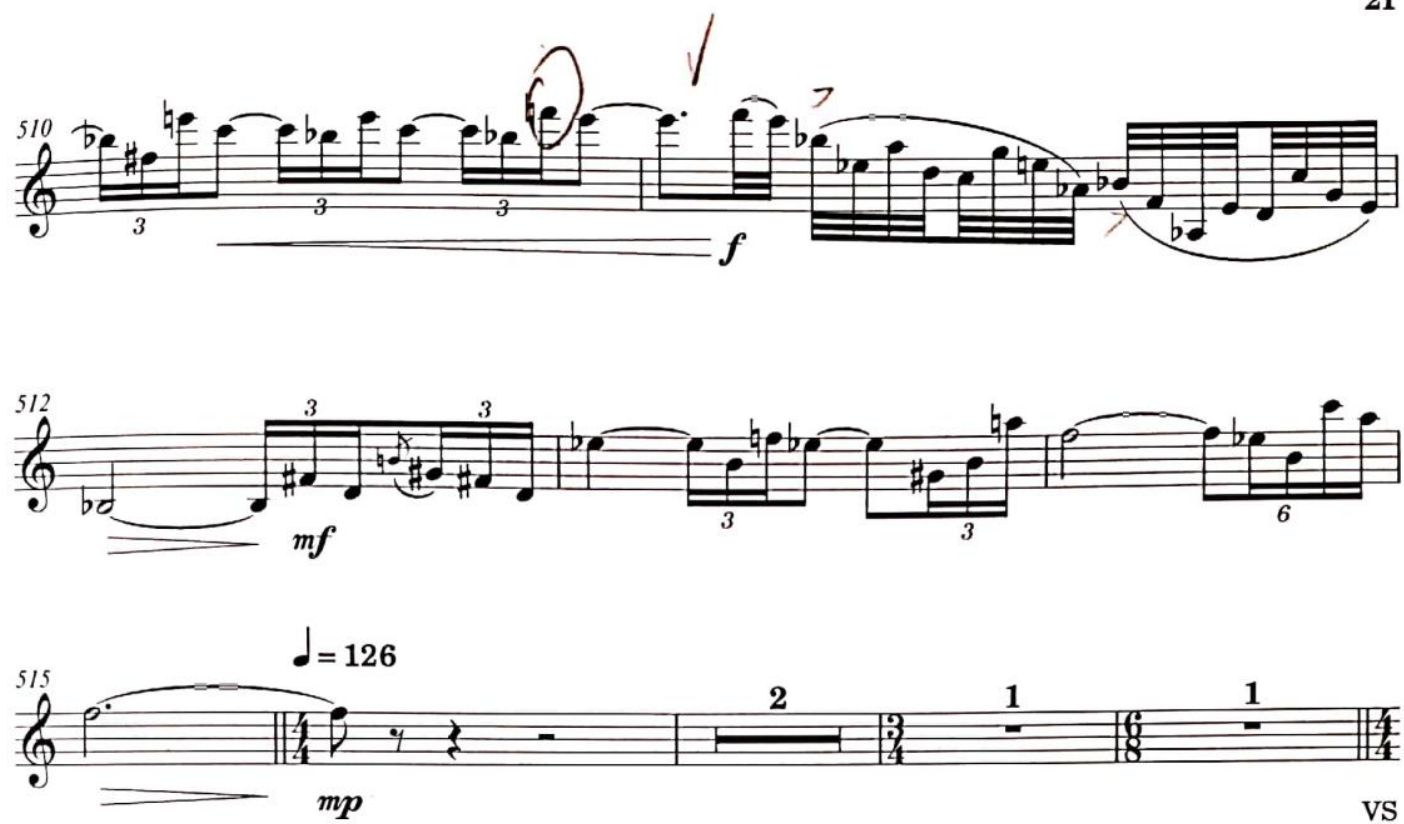

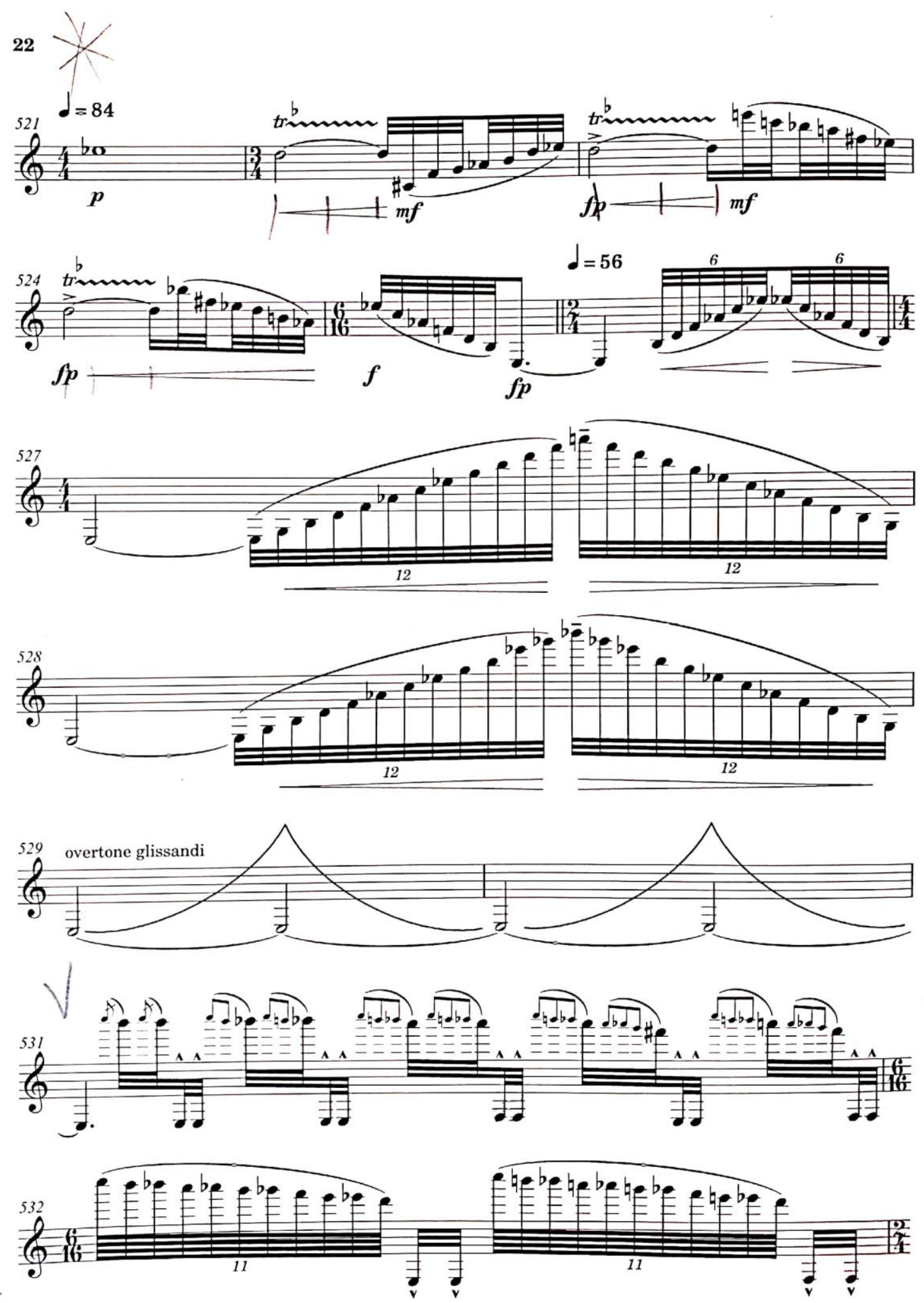

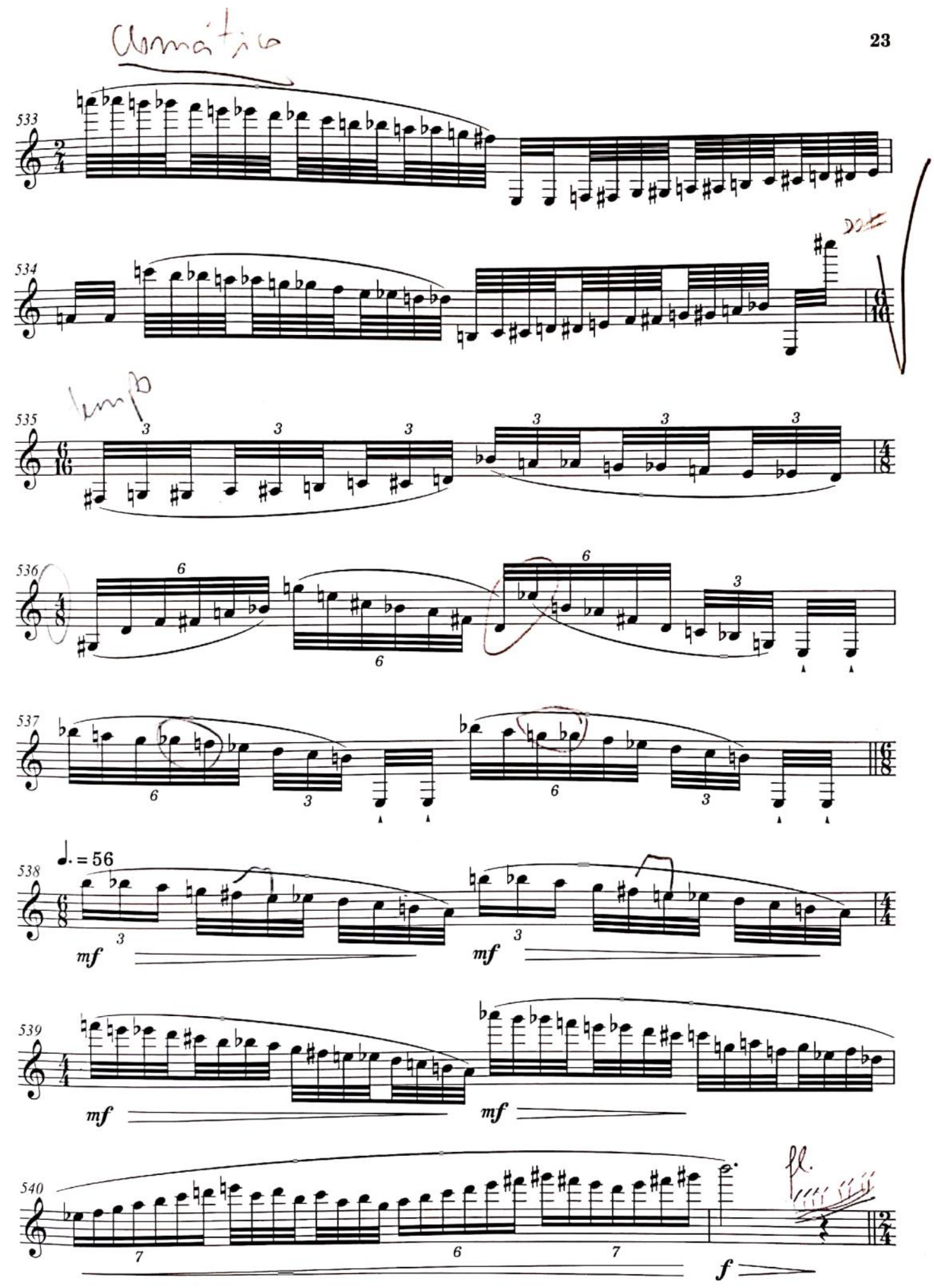

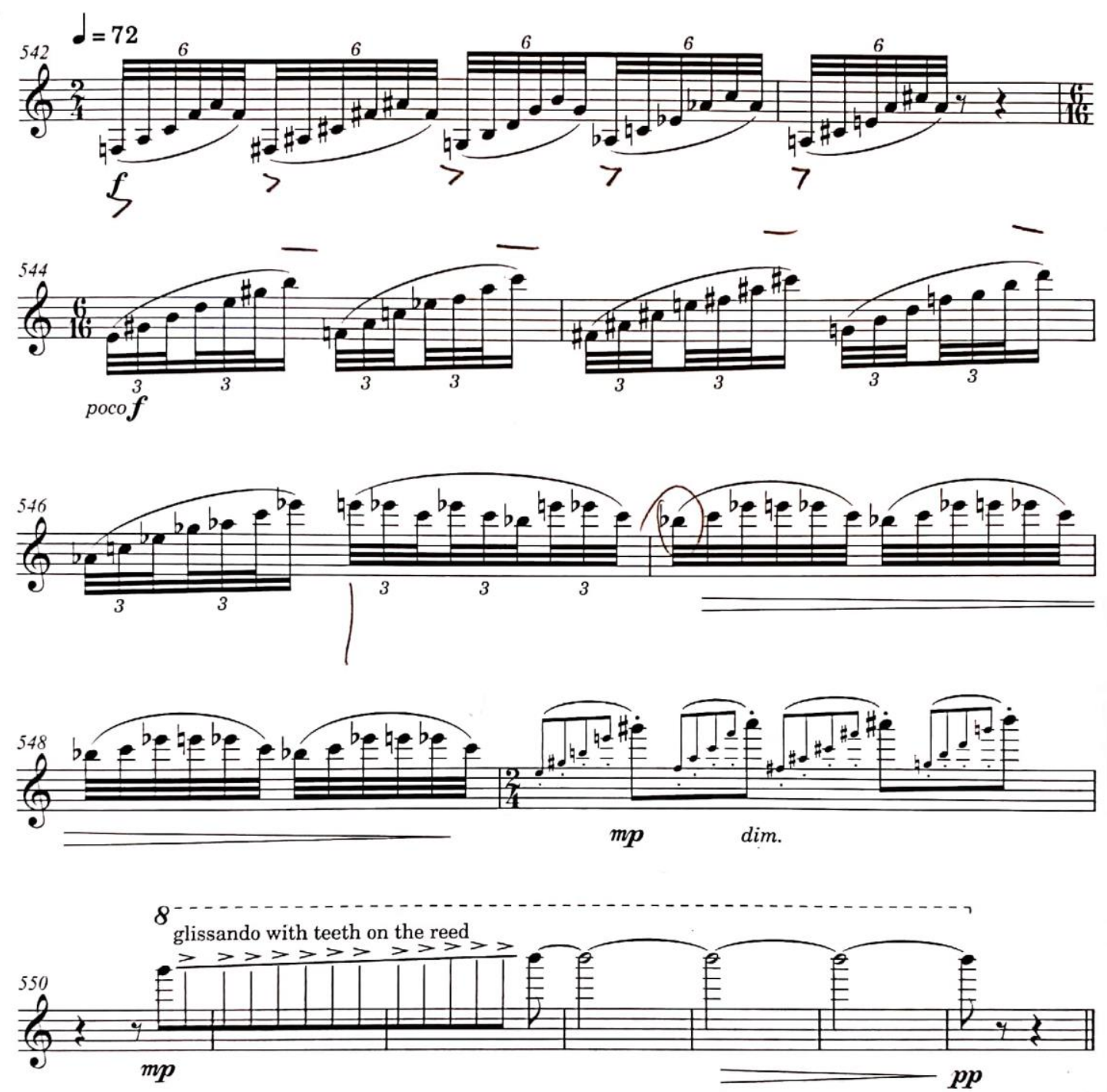

Cadenza

557 ad lib.

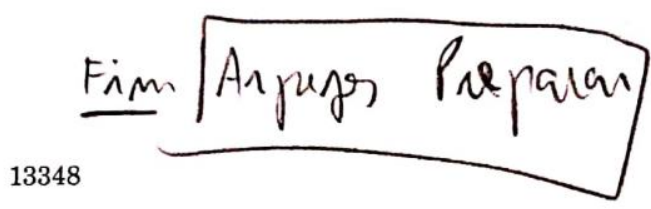

Fonte: LINDBERG, 2013 
24

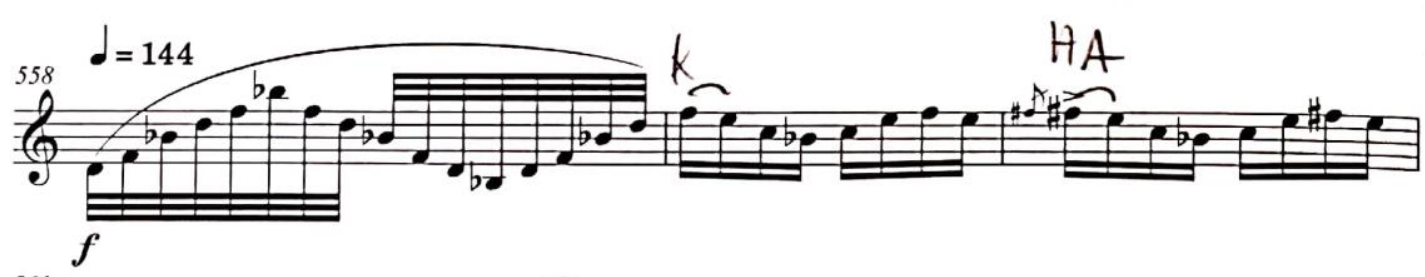

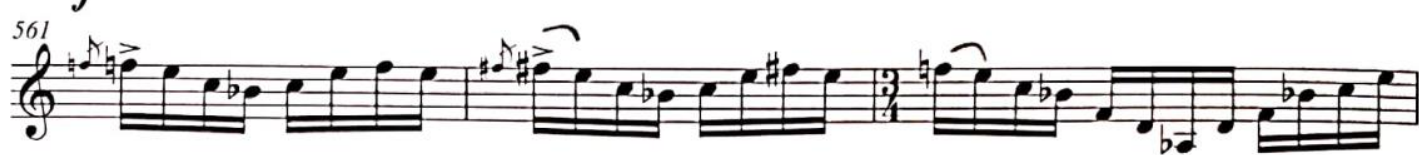

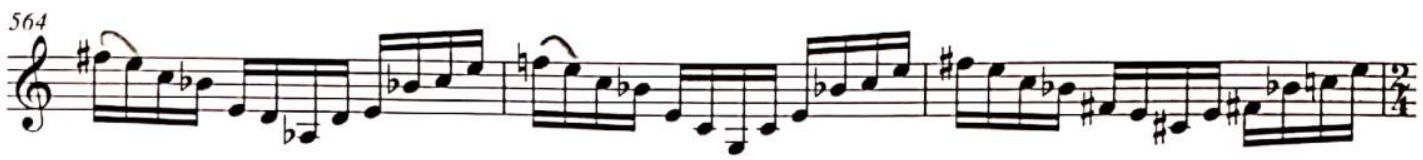
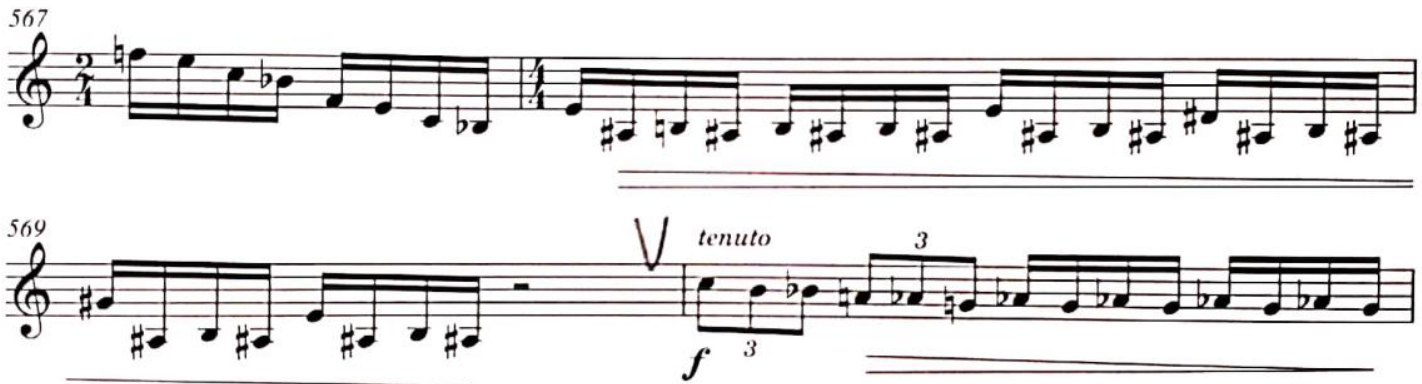

$6 f^{3}$
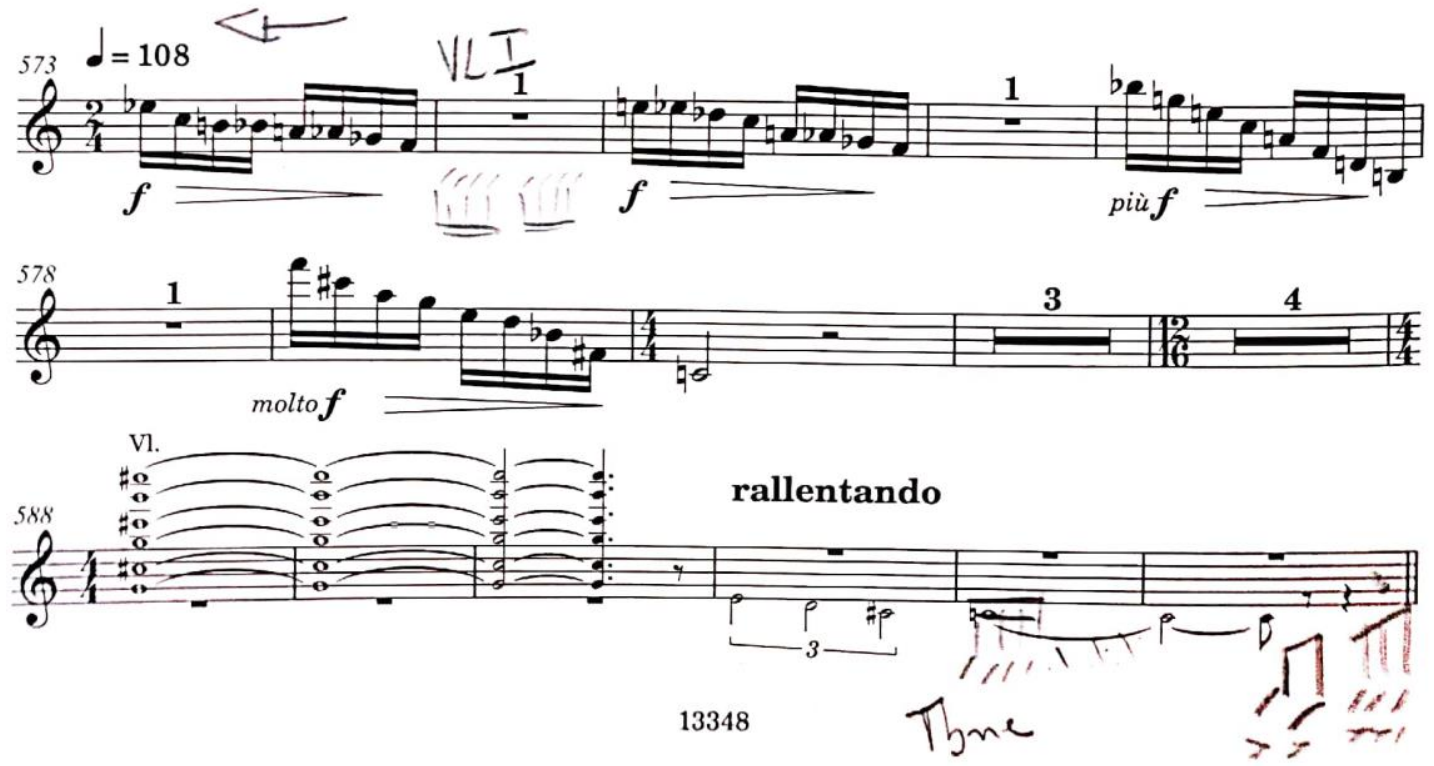

Fonte: LINDBERG, 2013 

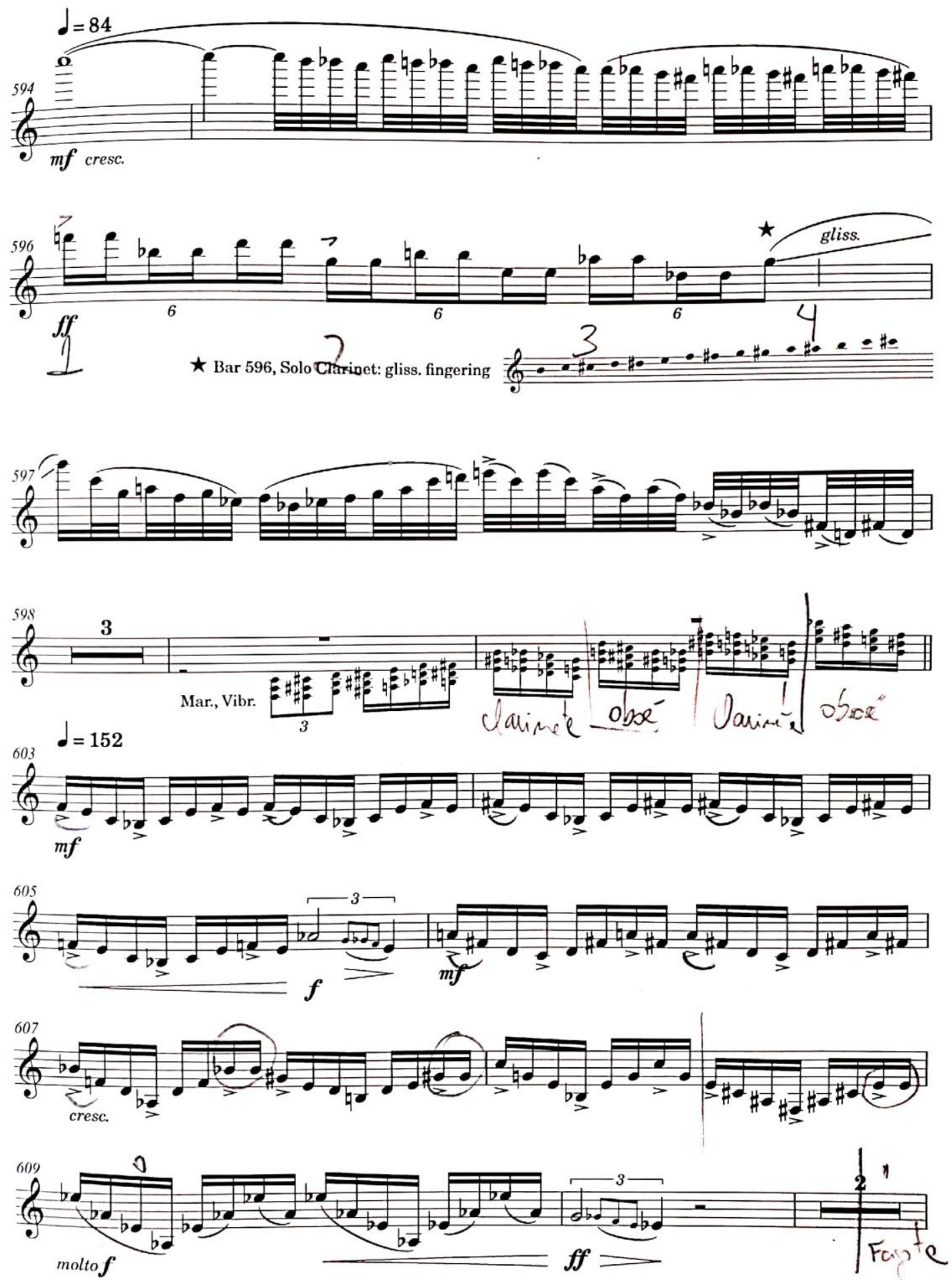

Fonte: LINDBERG, 2013 
26

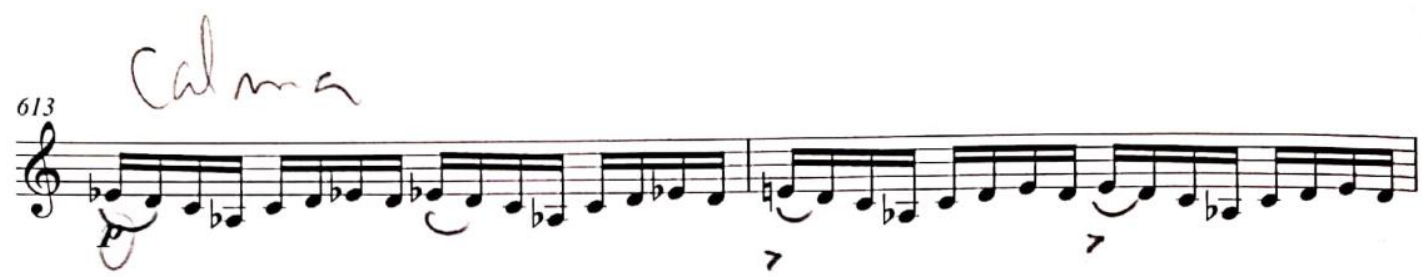

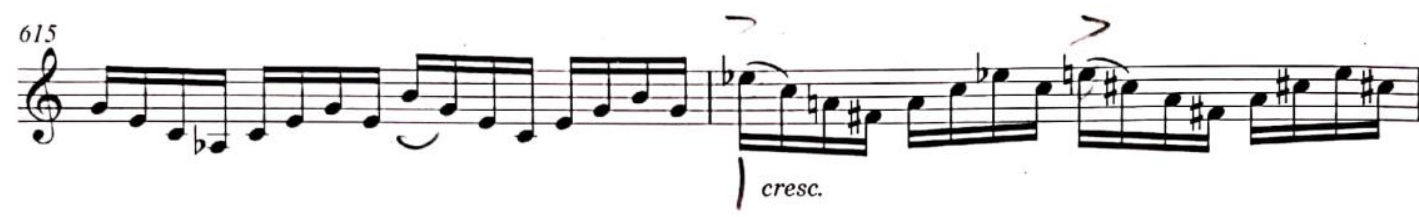

(6)
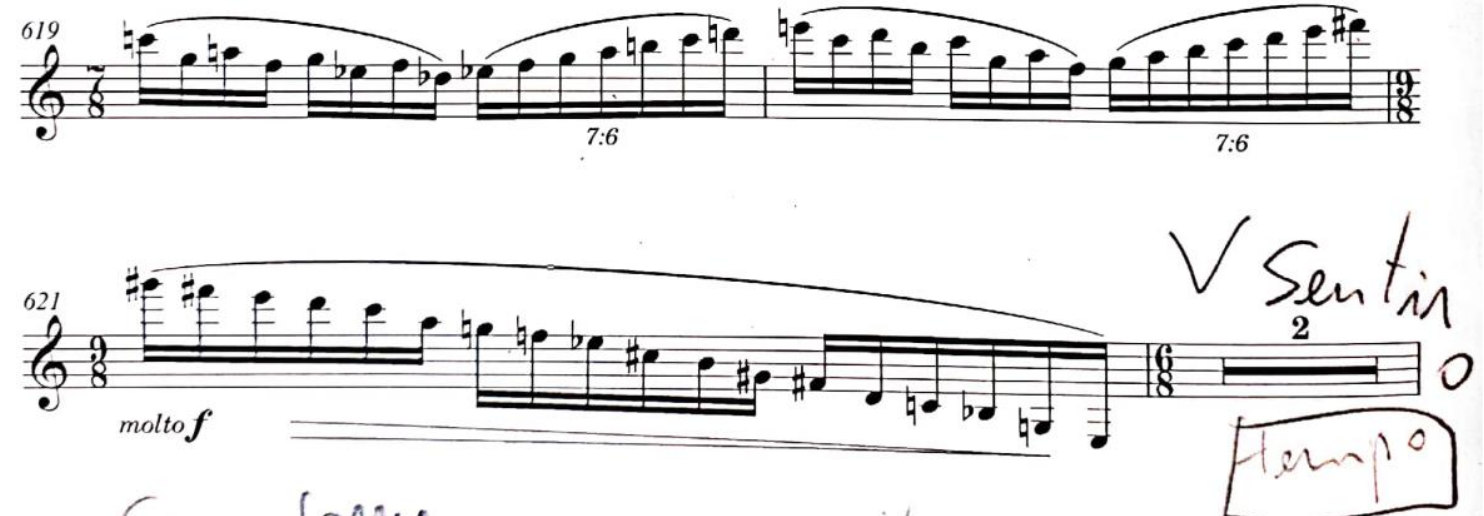

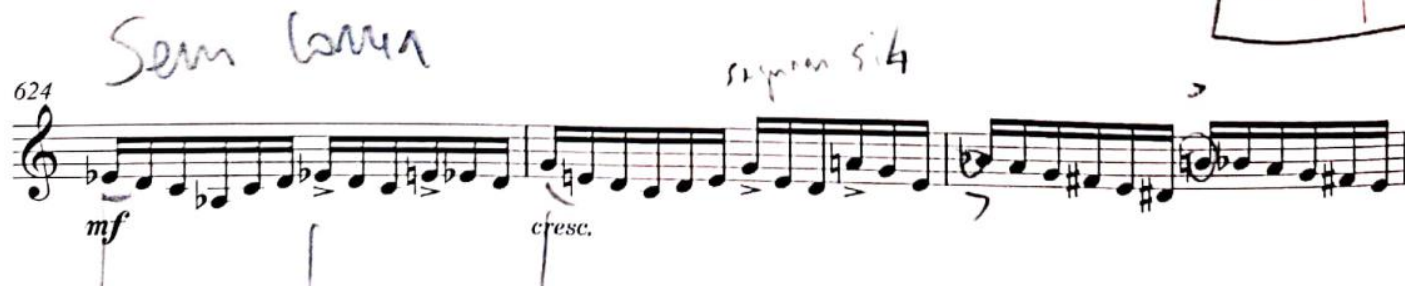

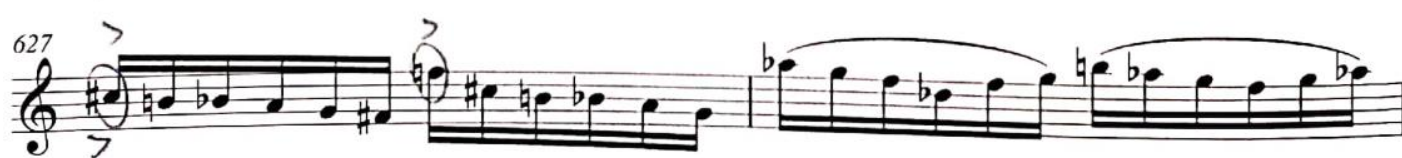
An 

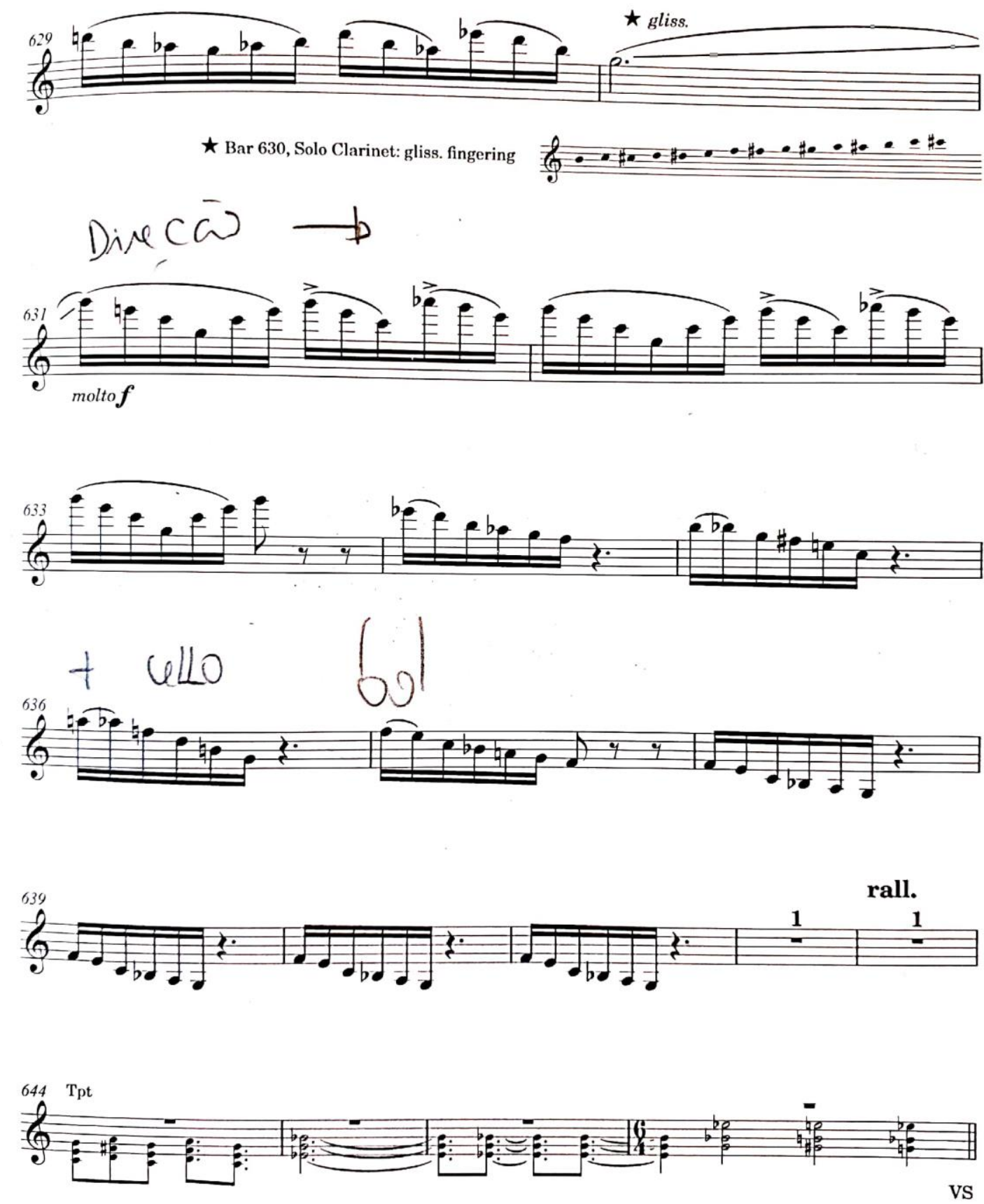

Fonte: LINDBERG, 2013 
28

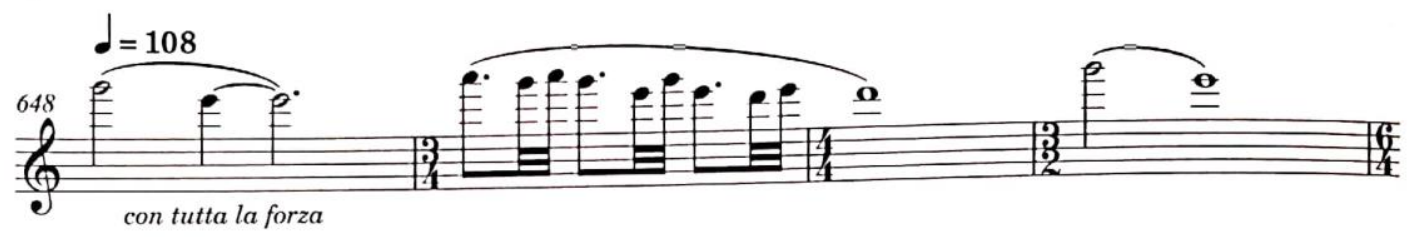

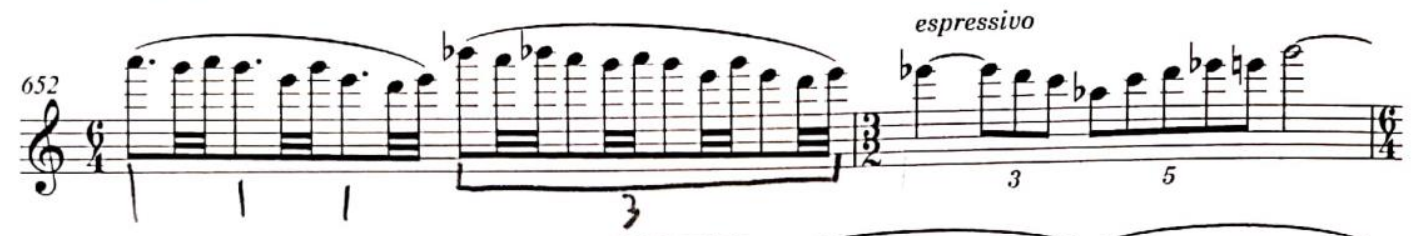

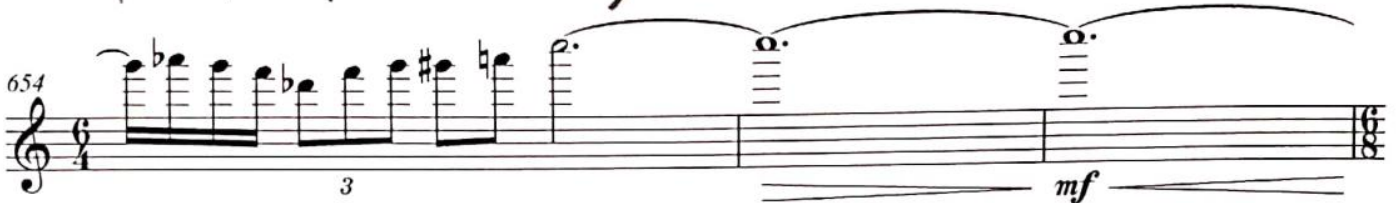

hi Wr molto rubato
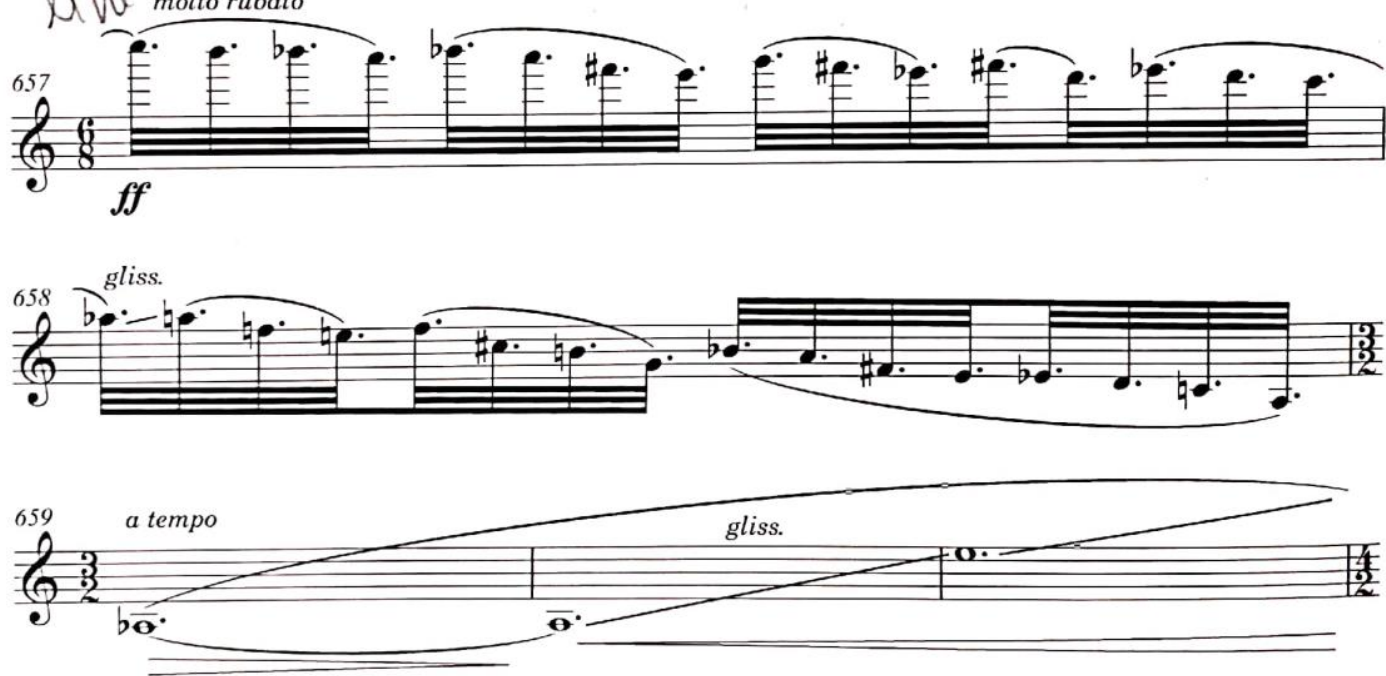

D. We rallentando
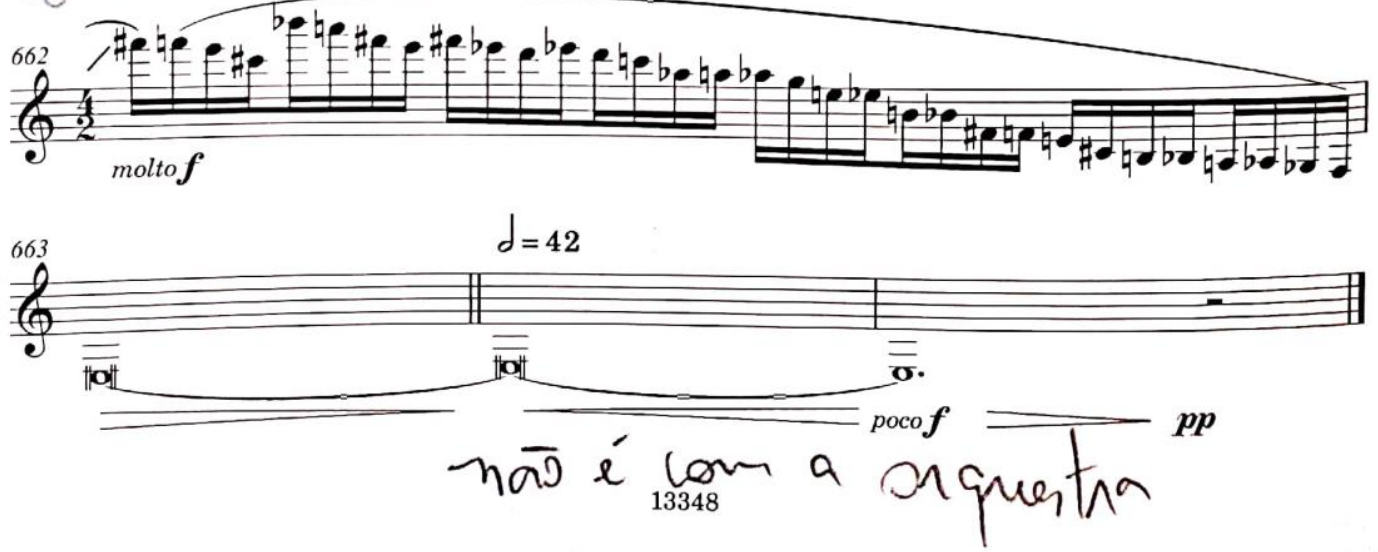